\begin{tabular}{|c|c|}
\hline Page 1 of 2 & 1 ECN 656402 \\
\hline
\end{tabular}

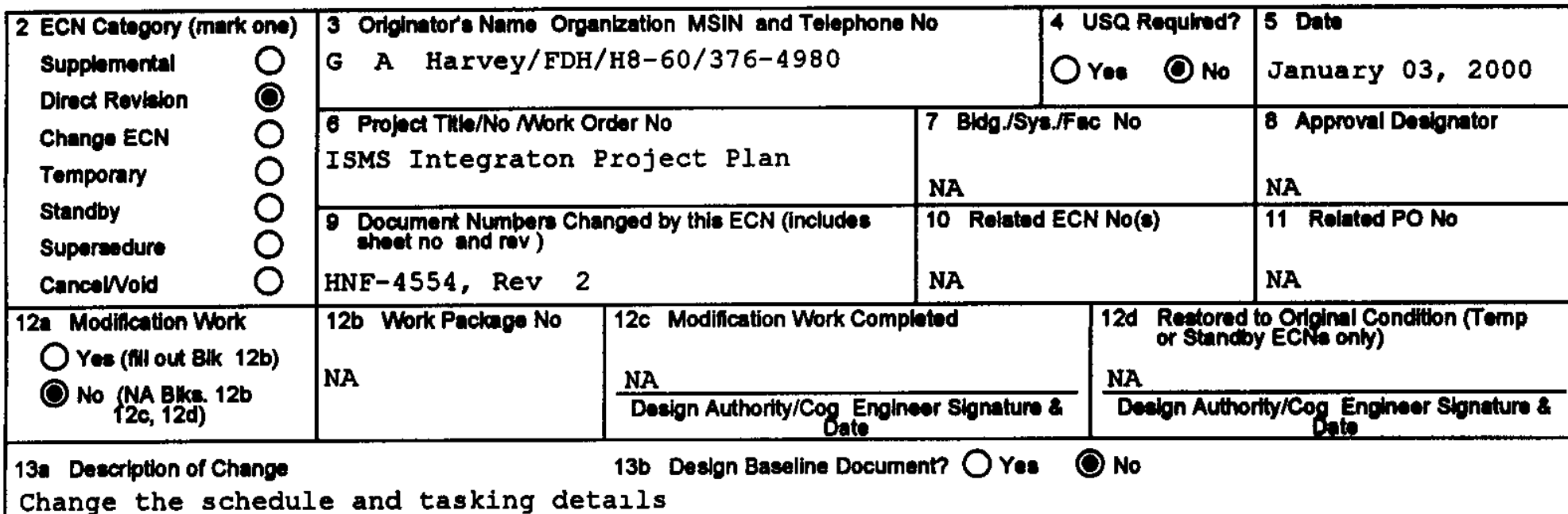

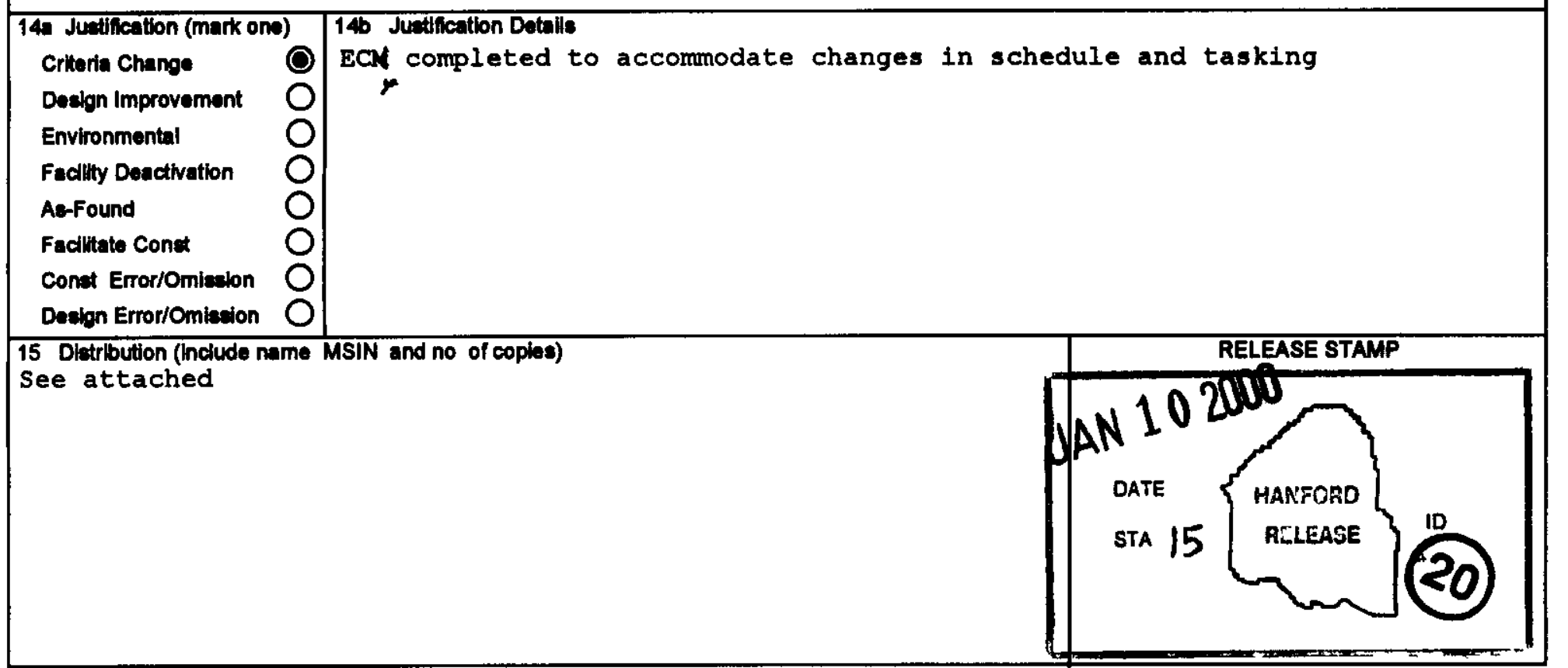




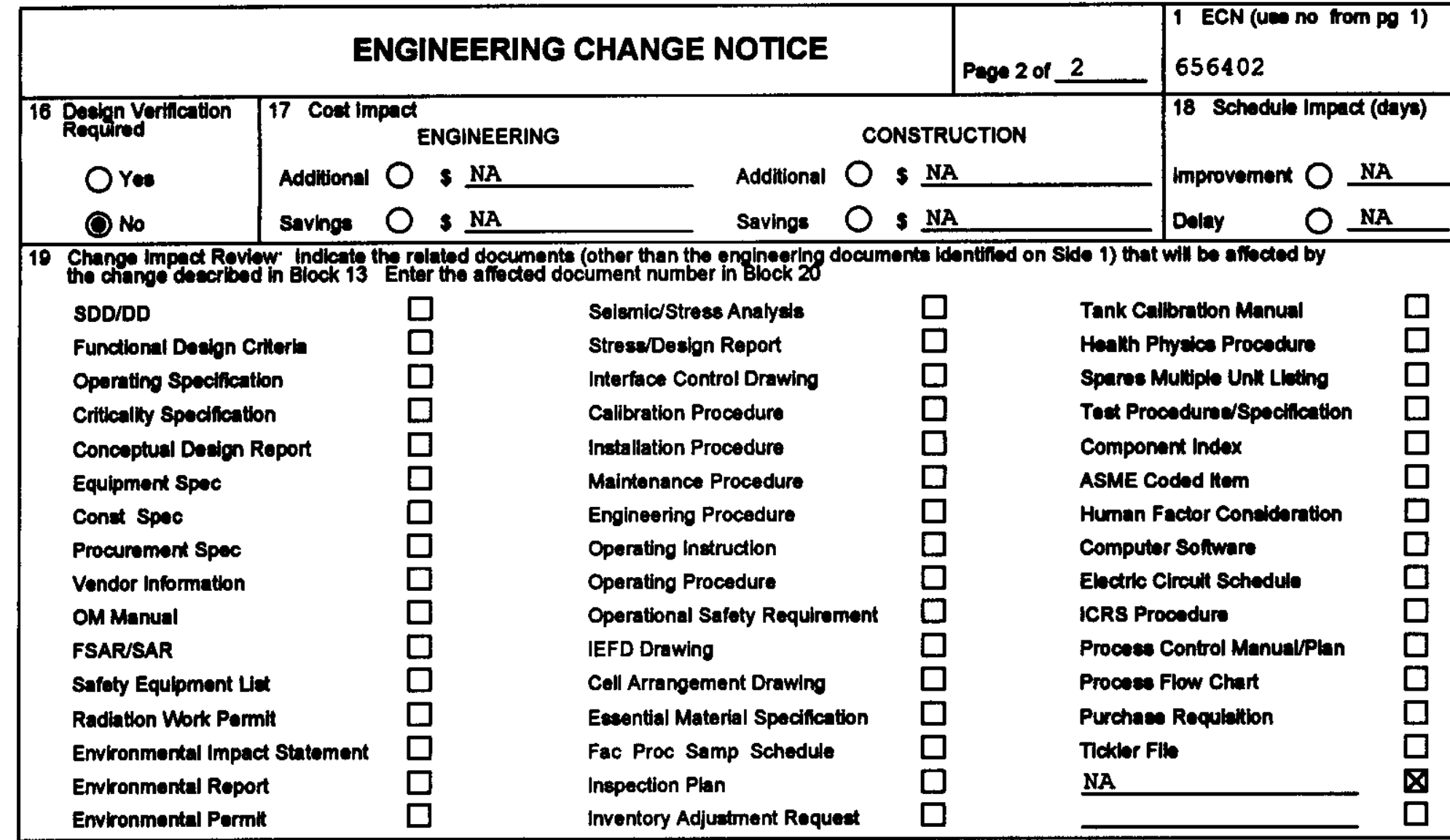

20 Other Aficeted Documents (NOTE Documents liked below will not be revised by thls ECN) Signatures below indicate that the signing organization has been notined of other alliected documents listed below

\section{Document Number/Rovlaton}

NA

NA
Document Number/Revieion

NA

Document Number/Revilion

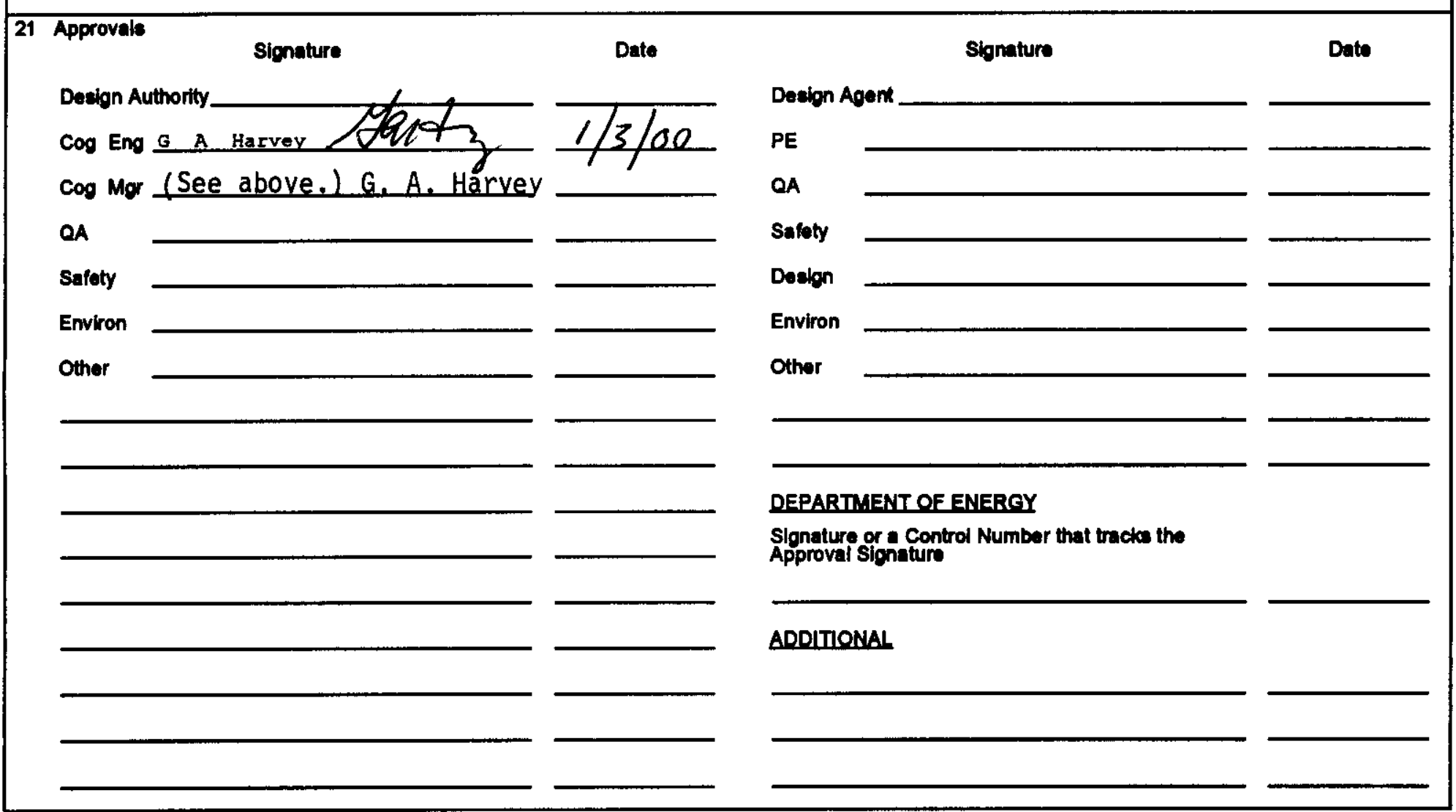




\section{DISTRIBUTION SHEET}

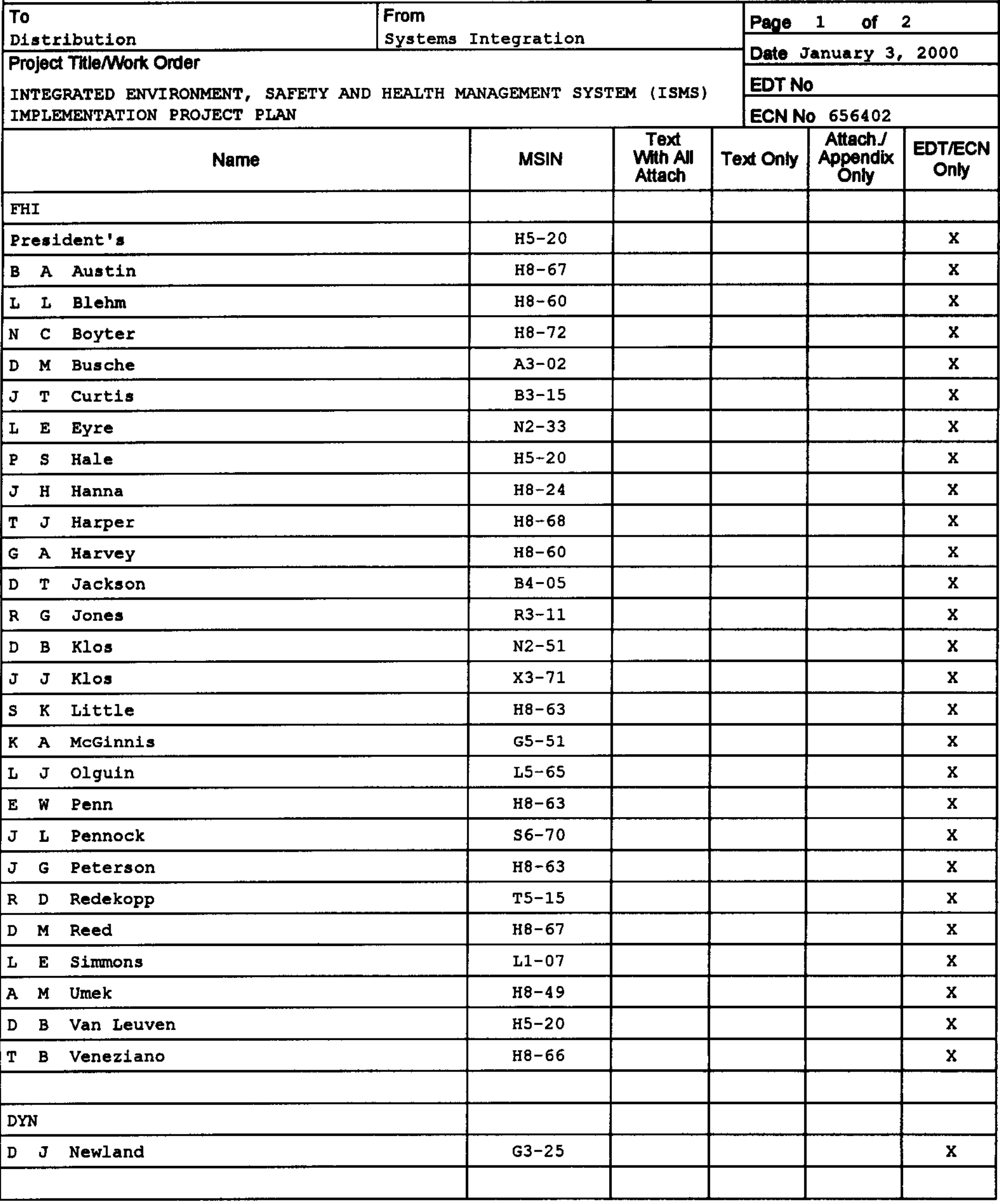




\section{DISTRIBUTION SHEET}

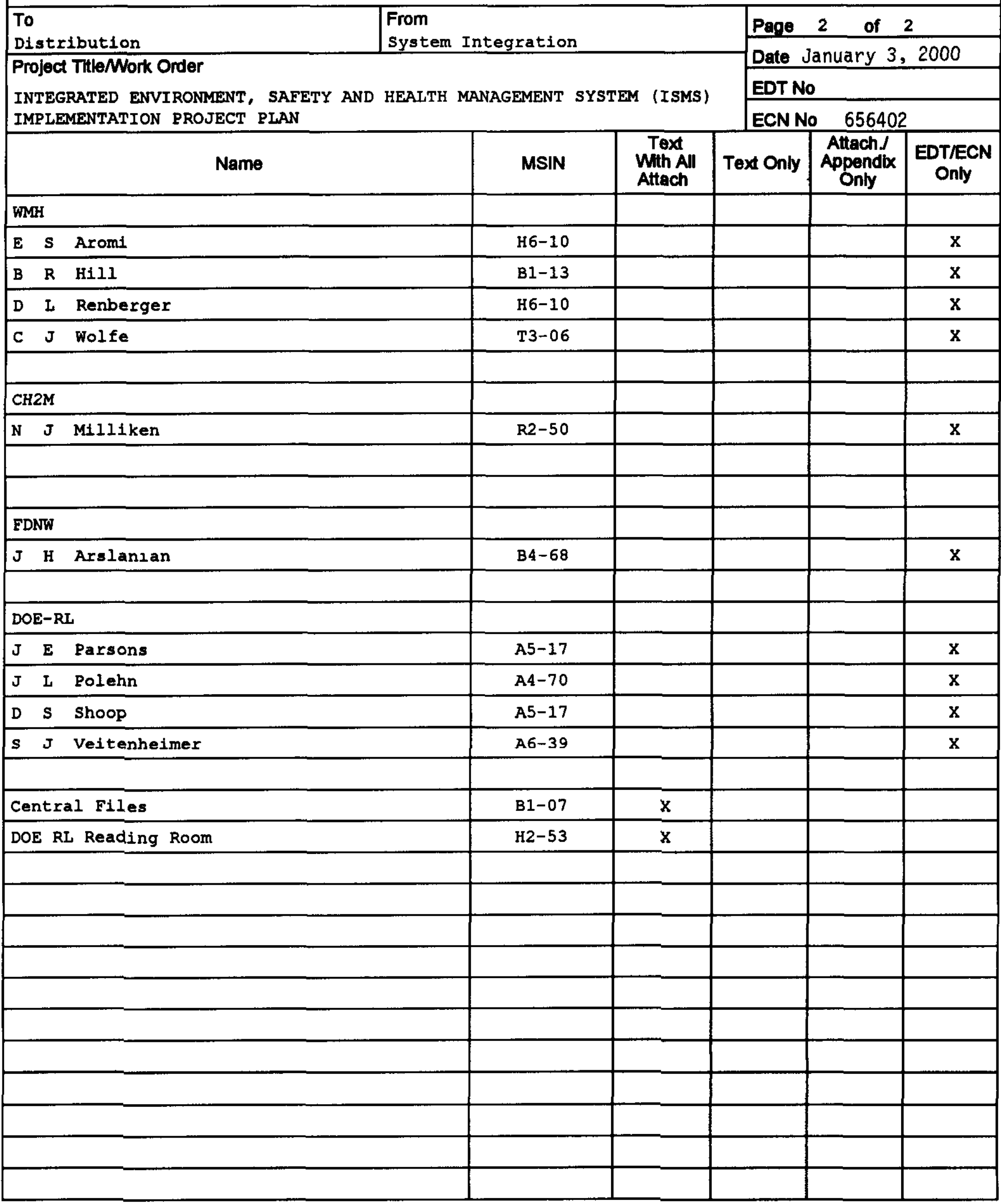




\section{INTEGRATED ENVIRONMENT, SAFETY AND HEALTH MANAGEMENT SYSTEM (ISMS) IMPLEMENTATION PROJECT PLAN}

G A Harvay

FDH

Richland WA 99352

U S Department of Energy Contract DE-AC06-96RL13200

$\begin{array}{llll}\text { EDT/ECN } & \text { ECN-656402 } & \text { UC } 2000 & \\ \text { Org Code } & 4 \text { R000 } & \text { Charge Code } 109184 / A J 60 \text { yM HFPO43I } \\ \text { B\&R Code } & \text { N/A } & \text { Total Pages } 67\end{array}$

Key Words Integrated Environment, Safety and Health Management system, Project Plan, ISMS, Safety

Abstract The Integrated Environment, Safety and Health Management system (ISMS) Implementation Project Plan serves as the project document to q guide the Fluor Hanford, Inc (FHI) and Major subcontractor (MSC) participants through the steps necessary tgcomplete the integrationof $\mu$ environment, safety, and health into manderment and work practices at all levels

TRADEMARK DISCLAIMER Roference herein to any specinc commercial product procese or service by trade name trademark manufucturer or otherwise does not necesearily conetitute or imply lie endoreoment recommendation or fevoring by the United States Government or any agency thereof or its contrectors or eubcontractors

Printed in the United States of America To obtain copies of this document contact Document Control Services P O Box 860 Malietop Ho-08 Richland WA 99352 Phone (509) 3722420 Fax (500) 378-4089

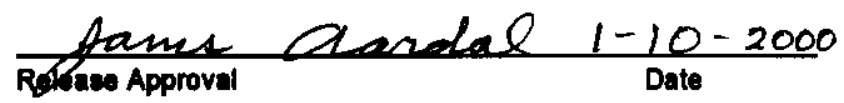

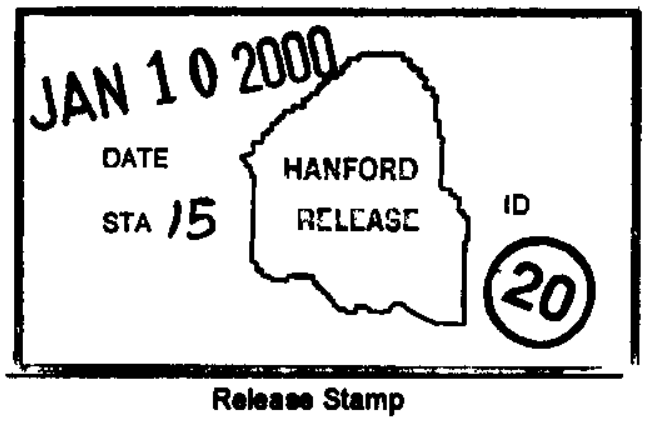




\section{RECORD OF REVISION}

$\operatorname{Page} 1$

(2) Tith

INTEGRATED ENVIRONMENT, SAFETY AND HEALTH MANAGEMENT SYSTEM (ISMS) IMPLEMENTATION PROJECT

PLAN

Change Control Record

(3) Rovicion

(4) Description of Change Replace Add and Delete Pages

(7)

EDT 623085 dated May 27, 1999

Revision to change schedule and tracking ECN-650797

Revision to change schedule and tracking ECN-656400

2 Revision to change schedule and tracking ECN-656401

3 RS Revision to change schedule and tracking ECN-656402
Authorizad for Rolease

(5) Cog Engr $\quad$ (6) Cog Mgr Date

\begin{tabular}{l|ll} 
G B & G A Harvey
\end{tabular}

Griffin

R I

Mitchel1

R L

Mitchell

I n. B/shm

政

\section{G A Harvey}

G A Harvey

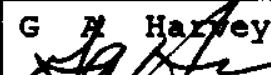

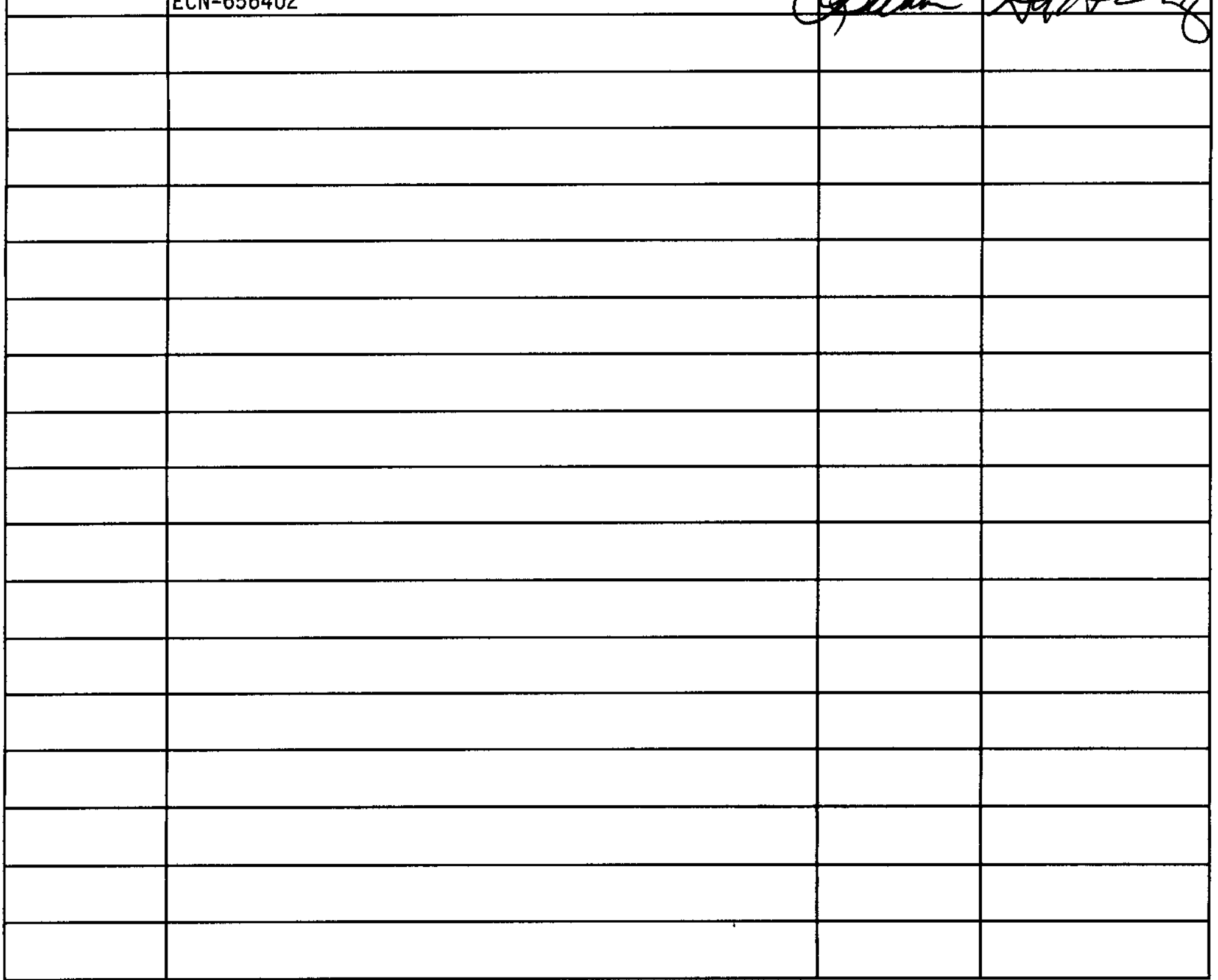




\title{
Integrated Environment, Safety and Health Management System (ISMS) Implementation Project Plan
}

\author{
HNF-4554, Rev 3
}

January 3, 2000

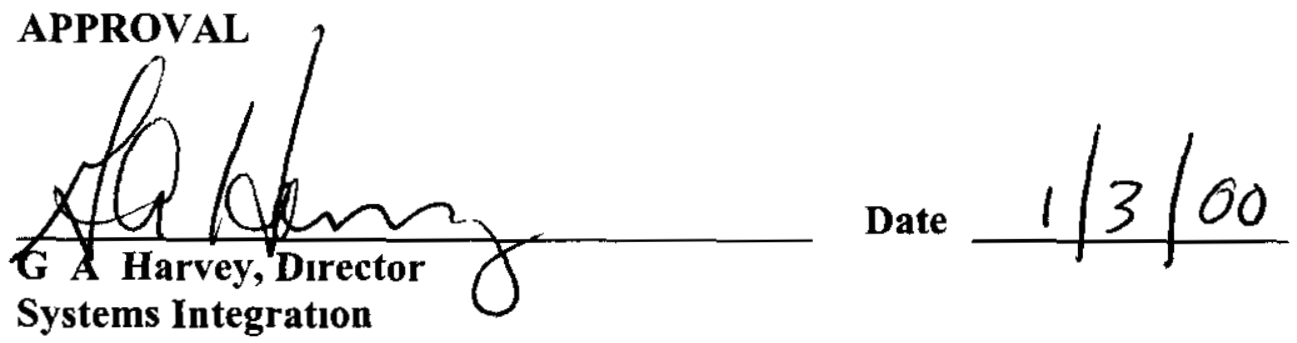

Fluor Hanford, Inc 


\section{CONTENTS}

10 PURPOSE

20 MISSION NEED AND OBJECTIVES

30 TECHNICAL PLAN

40 MANAGEMENT APPROACH

50 ACQUISITION STRATEGY

60 PROJECT SCHEDULE

70 RESOURCE PLAN

80 CONTROLLED ITEMS/BASELINES

90 PROJECT CHARTER

ATTACHMENTS

Attachment 1 - FHI ISMS Corrective Action Plan

Attachment 2 - FHI ISMS Improvement Plan

Attachment 3 - FHI Verification Schedule 


\section{Integrated Environment, Safety and Health Management System (ISMS) Implementation Project Plan}

\section{PURPOSE}

This plan describes how Fluor Hanford Inc (FHI) will conduct the activities necessary to complete ISMS verification throughout the Project Hanford Management Contract (PHMC)

\section{MISSION NEED AND OBJECTIVES}

The FHI Systems Integration organization is responsible for directing the implementation of ISMS across the PHMC The objectives of this Implementation Project Plan are described below

\section{Develop, Complete and Verify the Corrective Actions for FH ISM System Description Approval}

The ISMS Implementation Project will direct the activities necessary to obtain final approval of the FHI ISM System Description

- Develop an FHI ISM System Description that describes the FHI management system and related documents ( $1 \mathrm{e}$ plans and system requirements), and project and service provider ISM System Descriptions

- Complete corrective actions from the FHI Phase I Verification necessary to obtain approval of the FHI ISM System Description

- Address all opportunities for improvement identified durnng the FHI ISMS Verification and track corrective actions and improvement actions to closure

\section{Provide Guidance in the Development and Implementation of PHMC Project and Service Provider ISMS Programs}

The ISMS Implementation Project will provide guidance and oversight to assist the projects and service providers in the following

- Implementation and verification of their ISMS Programs

- Successful completion of Phase I and II Verifications by all PHMC projects and service providers on or before September 302000

\section{Verify Mechanısms are in Place to Sustain, Measure and Improve the PHMC ISMS}

The ISMS Implementation Project will provide guidance and coordination to verify mechanisms are implemented to 
- Annually update ISMS performance objectives, performance measures, and commitments for ISMS implementation, and submit an annual update report to the U S Department of Energy (DOE) Richland Operations Office (RL)

- Annually measure ISMS implementation effectiveness against performance objectives and commitments, through line management self-assessments and Facility Evaluation Board validations

- Annually identıfy and allocate resources to meet ISMS performance objectives and measures

- Update roles responsibilities and authorities documentation as needed

\section{TECHNICAL PLAN}

The FHI Phase I Verification assessment was completed in October 1999 and the Spent Nuclear Fuel (SNF) Phase I/II Verification assessment in November 1999 Corrective actions are necessary in order to obtain final approval of ISMS implementation for both FHI and SNF

Identıfied correctıve actions include simplifying the FHI Management Plan and ISM System Description and providing clear flow down to projects and subcontractors The schedule and structure of the remaining verifications across the PHMC also needs clanfication

FHI corrective actions and improvement opportunities will be formally managed through closure Project corrective action plans will be submitted to, and approved by, the ISMS Implementation Project Manager Corrective actions will be tracked by the ISMS Implementation Project Project improvement plans will be approved by the respective Project Director Attachments 1 and 2 will be used to manage and document completion of FHI commitments These will be updated as necessary to reflect current status and/or additional activities as identified during scheduled verifications

The remainıng ISMS verifications will be conducted at the project level, (1 e Nuclear Material Stabilization Waste Management River Corridor, etc ) consistent with FHI's recent alıgnment to a project-oriented management structure Accordingly, the scheduled verifications have been modified to fit the new organization In general, project verifications will be led by a DOEqualıfied ISMS Verffication Team Leader When a service provider verification is deemed necessary, the verification will be led by a FHI appointed team

Verification will be conducted against Project and Service Providers ISM System Descriptions, which will be consistent with, and included by reference into, the FHI ISM System Description System Descriptions will include requirements for ensuring operations are compliant with DOE Policies 450 4, 450 5, 4506 and the DEAR Safety Management System Contract Clauses Authorization Agreements will be developed and approved for all Category 2 Nuclear Facilities prior to Phase II verifications

Accomplishment of these actions is consistent with and satisfies the PHMC fiscal year 2000 Comprehensive Performance Expectations 


\section{MANAGEMENT APPROACH}

Responsibilities for and major activities of PHMC organızations are defined as follows

The FHI Systems Integration Director is responsible for the overall implementation of the PHMC ISMS and completion of Implementation Project Plan objectives

The FHI ISMS Implementatıon Project Manager is responsıble for planning, directıng and coordinating the performance of the tasks described in this Project Plan Examples of tasks in this scope include, but are not limited to

- Supporting and mentoring Senıor line management ownership of ISMS implementation throughout the PHMC

- Communicating with the projects and service providers

- Conducting structured readiness reviews against the Criteria Review and Approach Documents (CRADs)

- Supporting strategy development for compliance with DOE P450 5

- Providing overview of the project and service provider process to declare readiness for verification

- Coordınatıng development of necessary correctıve actions resulting from verifications and approving project and service provider corrective action plans

- Conducting project meetıngs as necessary

- Communicating ISMS Lessons Learned across the PHMC

- Facilitating RL overview of the process for declarıng readiness by the projects and service providers

- Maintaining/updating this ISMS Implementation Project Plan

- Defining the requirements for ISMS implementation traınıng including training for the projects and service providers

The Vice President of Environment Safety and Health (ES\&H) is responsible for the FHI ISM System Description and for providing FHI Systems Integration with technical support for the performance of the tasks described in this Project Plan Examples of tasks in this scope include, but are not limited to

- Maintainıng and updatıng HNF-MP-003, FHI ISM System Description

- Directing and approving revisions to the project and service provider ISM System Descriptions, and ensuring their consistency with the FHI ISM System Description

- Participating in assessments in accordance with the strategy developed for compliance with DOE P450 5

- Interpretıng/determınıng ISMS requirements including ISMS trainıng

The FHI Vice President of Site Services is responsible for providing support and administration of the Automated Job Hazards Analysis (AJHA) tool Examples of tasks in this scope include, but are not limited to 
- Providing refresher trainıng and "mock interviews for managers and workers

- Establishing an office with computers, phones, faxes, and copy machines and administrative support for the Verification Team

\section{ACQUISITION STRATEGY}

Procurement of hardware other than normal office equipment is not anticipated to be required for this Project

To augment avallable resources within the PHMC, it may be necessary to secure expertise avallable from consulting firms In these instances, these services will be obtained using the approved process for obtaining this type of support

\section{PROJECT SCHEDULE}

FHI and RL have jointly established and agreed to a PHMC Verification Strategy and Schedule that identifies dates for completion of the PHMC verification That document is maintained and controlled by the FHI ISMS Implementation Project Manager as Attachment 3 This attachment will be revised mutually by FHI and RL as necessary to reflect site priorities, and resource and scheduling constraints The PHMC Verification schedule is summarized below

\section{Organization}

Fluor Daniel Hanford, Inc Spent Nuclear Fuel Site Services (DynCorp) Nuclear Material Stabilization Fast Flux Test Facility

River Corridor Waste Management Analytical Services Protection Technology Hanford
Verification Date

October 1999

November 1999

December 1999

January 2000

April 2000

May 2000

May 2000

May 2000

March 2000

\section{Verification Team}

DOE

DOE

FHI

DOE

$\mathrm{FHI}$

DOE

DOE

FHI

\section{RESOURCES PLAN}

The following resources from the FHI Systems Integration and ES\&H organizations are required to support this Project Similar levels of resources will be needed by the projects and service providers

- ISMS Implementation Project Manager

- ES\&H ISMS Director

- Project and service provider ISMS coordinators 
- PHMC Level implementation coordinators (in support of the ISMS Implementation Manager)

- Administrative Assistance (in support of the ISMS Implementation Project Manager)

- Field implementation consultant and support

\section{CONTROLLED ITEMS/BASELINES}

The project-controlled baseline consists of the following

- Date of Authorization Agreement approval (as applicable for Category II nuclear facilities)

- Date of readiness declaration by the projects and service providers for Phase I and/or Phase II Verifications

- Date of Phase I and/or II Verifications

The dates provided in the PHMC Verification Strategy and Schedule reflect the latest planning and have been coordinated with RL If necessary, further revisions to those dates will be made in conjunction with $\mathrm{RL}$

\section{PROJECT CHARTER}

The FHI Director of Systems Integration is responsible for the completion of the ISMS Implementation Project Plan objectives The Director of Systems Integration reports to the Executive Vice President of FHI The Executive Vice President of FHI is the senior management sponsor for implementation of ISMS throughout the PHMC The FHI Vice President of ES\&H is responsible for providing support for the completion of the tasks defined in this Plan The ISMS Implementation Project Manager manages the tasks associated with this project $\mathrm{He} / \mathrm{sh}$ is accountable to the Director of Systems Integration for this activity

Each project and service provider will appoint an ISMS Coordinator This person will provide liaison with FHI Systems Integration and serve as the lead for implementation activities within his/her project or service provider 
HNF-4554, Rev 3

Attachment 1

Fluor Hanford, Inc

Integrated Environment, Safety and Health

Management System

\section{CORRECTIVE ACTION PLAN}

Consistıng of 13 pages 


\section{INTRODUCTION}

The U S Department of Energy Richland Operations Office (RL) completed a Phase I Verification of the Fluor Hanford, Inc (FHI) Integrated Environment, Safety and Health Management System (ISMS) in October 1999 This review resulted in 32 Opportunities for Improvement, 2 Observations, and 14 Noteworthy Practices RL and FHI have categorized eight of these Opportunities for Improvement as Corrective Actions that will require valıdation by $R L$ prior to closure

All Opportunities for Improvement have been evaluated and processed in accordance with HNF-PRO 052, Corrective Action Management and assigned a risk rank value determined by the deficiency evaluation group meetıngs All issues have been screened for Price Anderson Amendment Acts significance

\section{FORMAT AND CONTENT OF CORRECTIVE ACTION PLAN}

This attachment contains the correctıve actions, whıch were identıfied as requirıng RL validation prior to FHI ISMS Description approval

Each Opportunity for Improvement and the associated commitments are documented using Closure Package Index/Cover Sheets These closure sheets provide

- Opportunity for Improvement statement

- ISMS functional area

- Lead Actionee

- Commitment statement

- Specific tasks, milestones and completion dates for those tasks

In addition, acceptance criteria are defined for each commitment These criteria will be used to support closure validation

Closure of commitments will require objective evidence to be presented to and approved by the validation authority for each Opportunity for Improvement 
HNF-4554 Rev 3

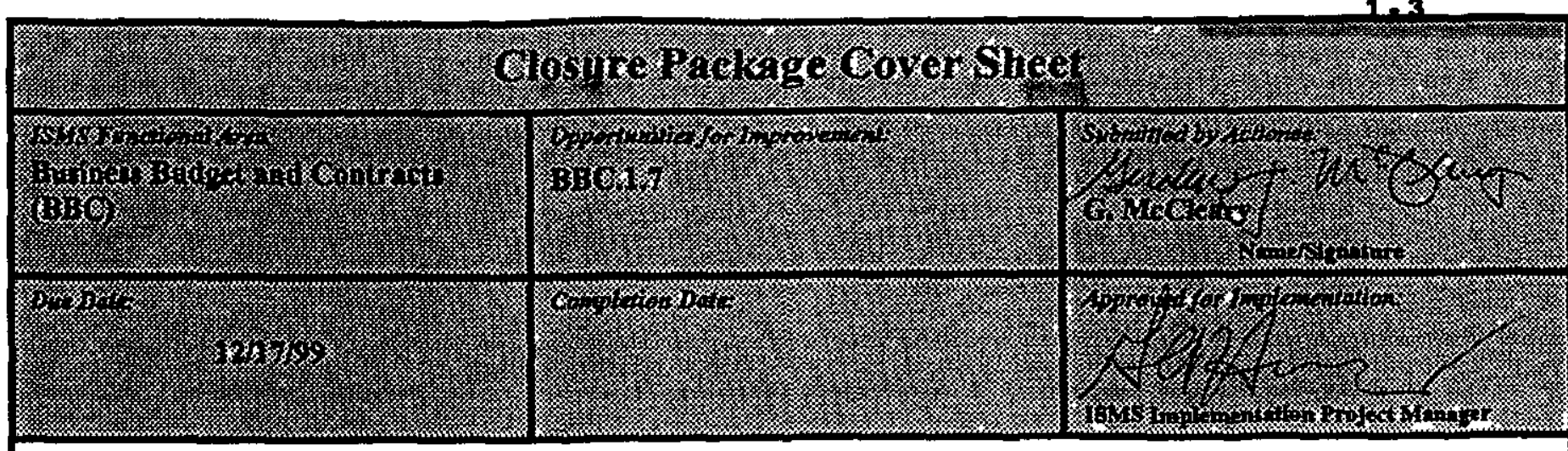

\section{OPPORTUNITIES FOR IMPROVEMENT}

ES\&H considerations are not formalized and are not an untegral element of the change control process Specifically, the change control process does not explicitly address how ES\&H implications of proposed changes are evaluated and addressed

Commutment FDH will modify HNF-PRO-533 Change Control procedure to include ES\&H representation on the Change Control Board

Subtask 01 Modify HNF-PRO-533 by December 17, 1999

\section{Acceptance Criteria}

Revision to HNF-PRO-533 approved

\section{Validation}

The following ovidonce (letter number reports etc) has been reviewed and are inchuded in the closurs package to validate the accuracy and completeness of the commitment

To be completed

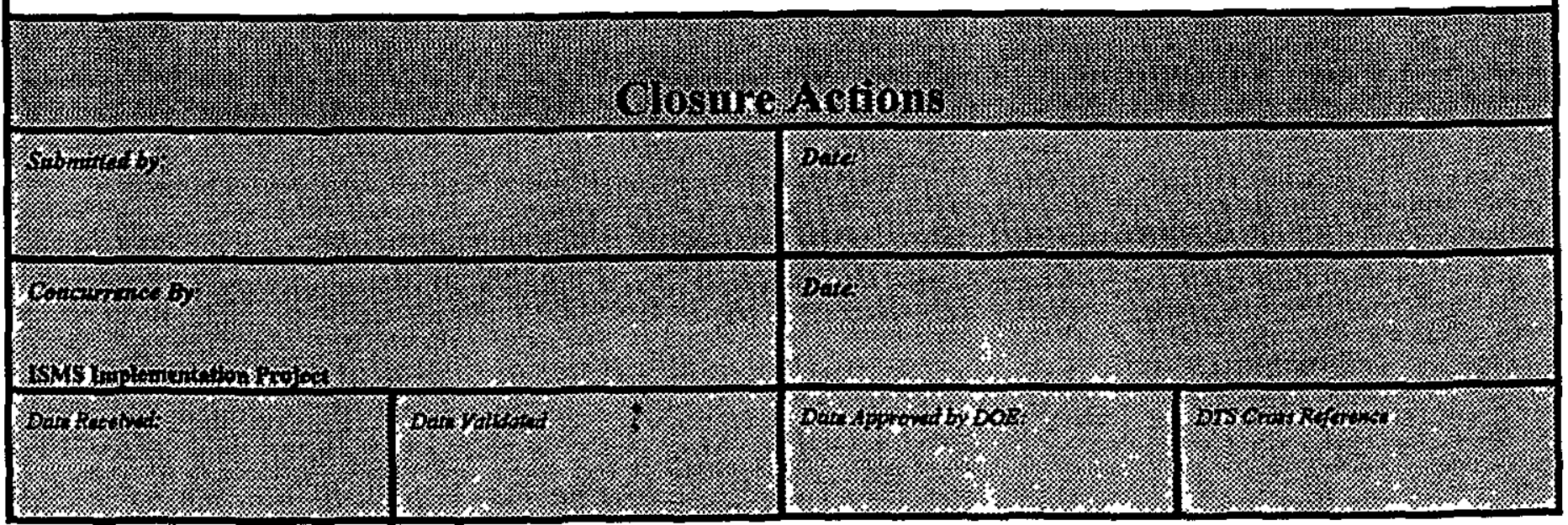




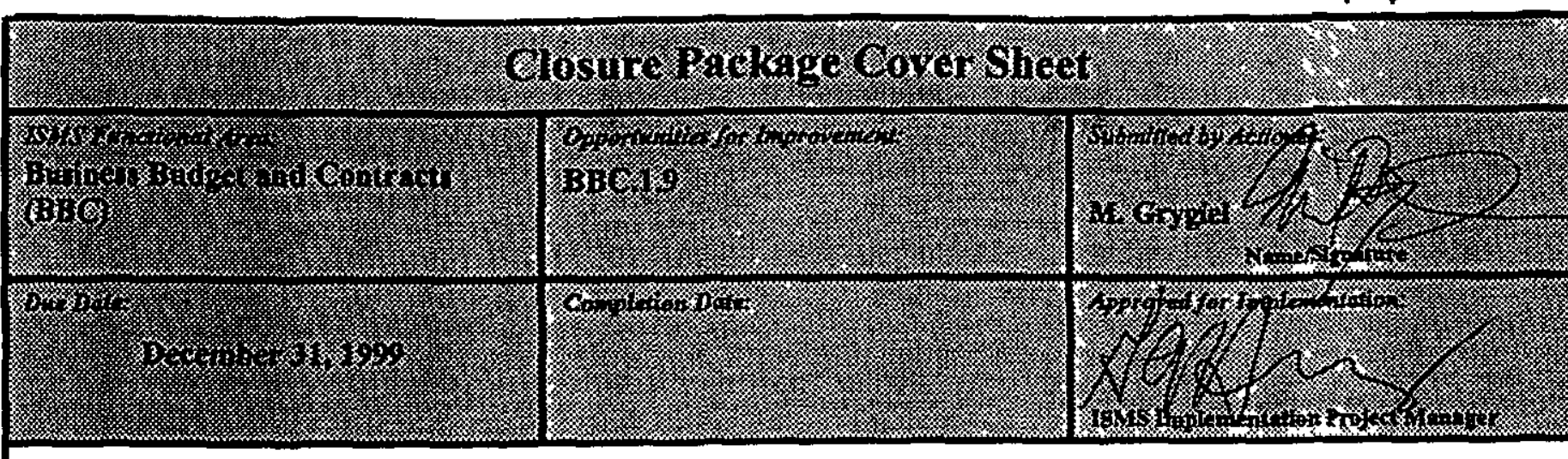

\section{OPPORTUNITIES FOR IMPROVEMENT}

The integration and linkages among FDH procedures needs to be more fully developed

\section{Commitment}

FDH has formed the Management Systems organization The organization has three missions

- Implement the requirements management initiative

- Identify key processes which are onented toward achieving work or providing services needed by the company

- Realign the existing procedures containing appropnate linkages to support the key business processes

\section{Subtask 01}

Develop Management System Upgrade Project Execution Plan by December 31, 1999

\section{Subtask 02}

Implement project plan and provide evidence of projects' positive impact

\section{Acceptance Critena}

Approved Management System Upgrade Project Execution Plan

\section{Validation}

The following evidence (Retier number reports etc.) has been reviewed and are included in the clasure package to validate the accuracy and completeness of the commitment

To be completed

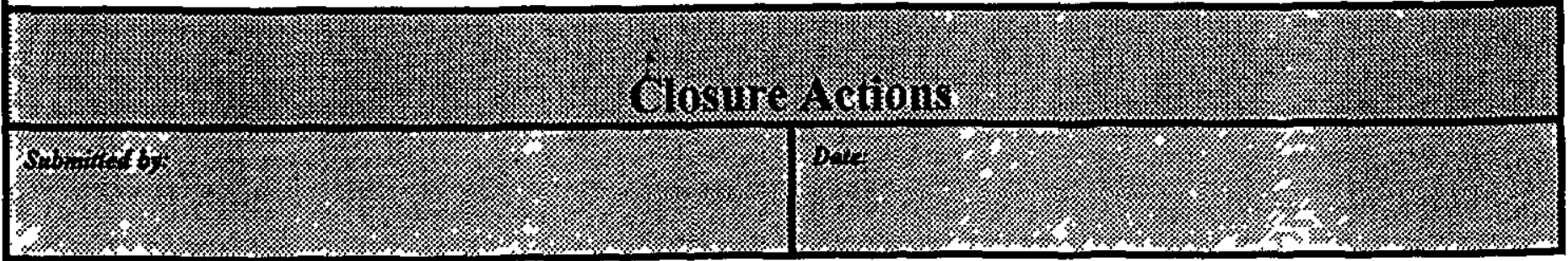




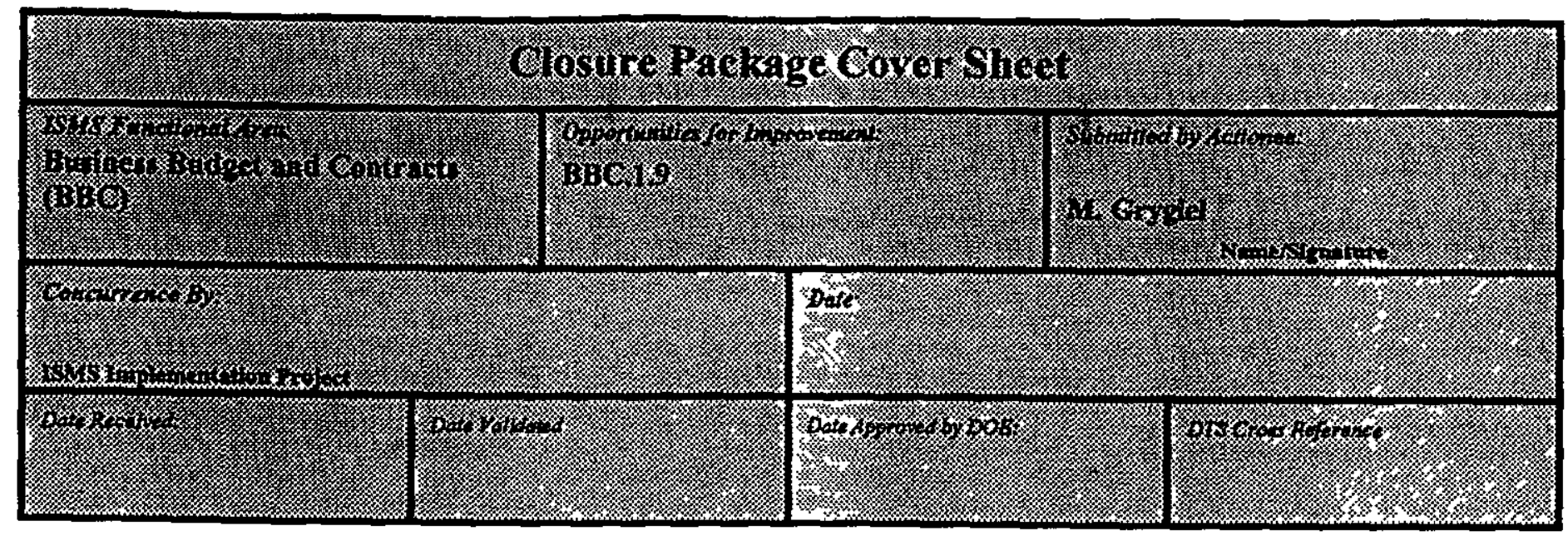




\section{Closure Package Cover Sheet}

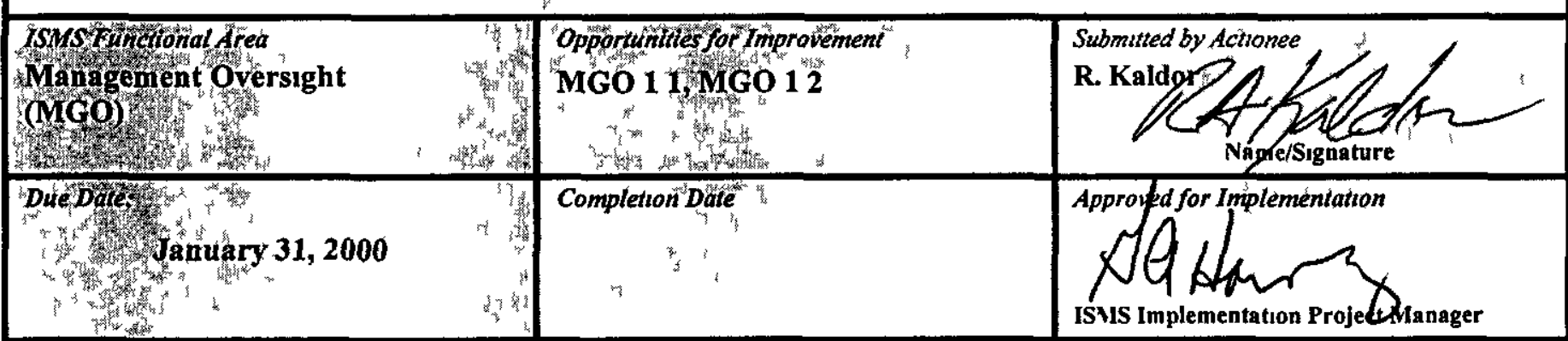

\section{OPPORTUNITIES FOR IMPROVEMENT}

MGO 11 FDH System does not clearly identıfy FDH line management with respect to defined functions roles, and responsibilities

MGO 12 FDH Plans procedures and roles and responsıbılitıes do not reflect the current FDH organization

\section{Commitment}

Revise HNF MP 001 Management Plan and HNF MP-003 FDH ISM System Description to be consistent with the new organization to simplify the system description and to clarify flow down to the worker level

\section{Subtask 01}

Complete and issue a revised HNF-MP-001 and HNF MP-003

Due Date January 15, 2000

Actionee $\mathbf{R}$ Kaldor

\section{Subtask 02}

Show Roles and Responsibilities for the new organization and ISMS concepts are clear and consistent throughout the revised HNF-MP 001 and HNF MP 003

Due Date January 15, 2000

Actionee $\mathbf{R}$ Kaldor

\section{Subtask 03}

Complete Strategic Steerıng Group review of the Management Plan (HNF MP 001) and ISM System Descriptıon (HNF MP-003) for contınuity clarity, and connectıvity throughout the new organization

Due Date January 31, 2000

Actıonee TW Halverson

\section{Acceptance Criteria}

HNF MP 001 and HNF-MP-003 approved

Objective evidence that the Strategic Steerıng Group has reviewed and validated the contınuty, clarity and connectivity of HNF MP 001 and HNF-MP 003 to the new organization

Note Approval of this closure package and closure package MGO 13 meets the criteria for Performance Incentive Item 1 B 2 as documented in Contract Number DE AC06 RL13200 M090 


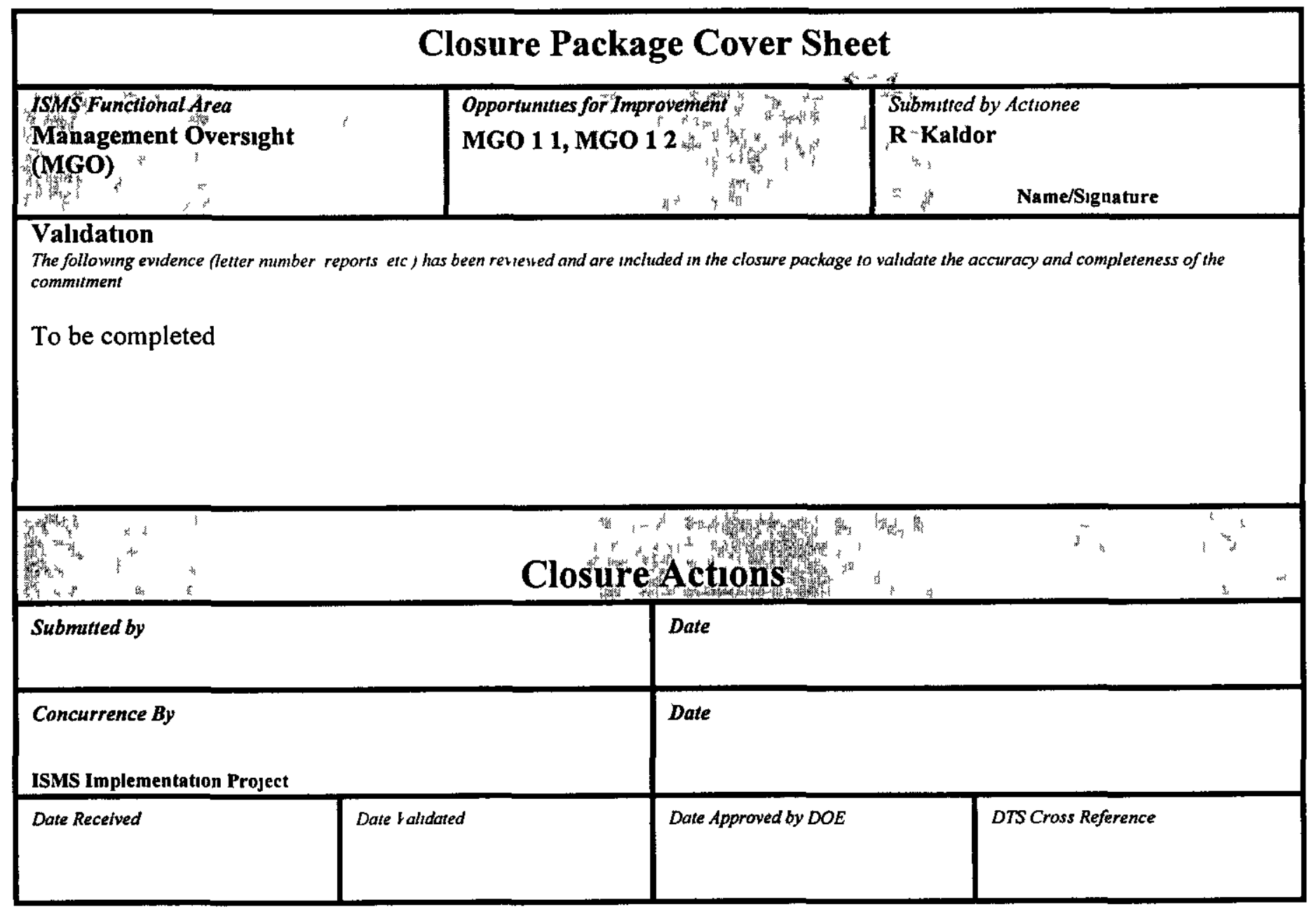




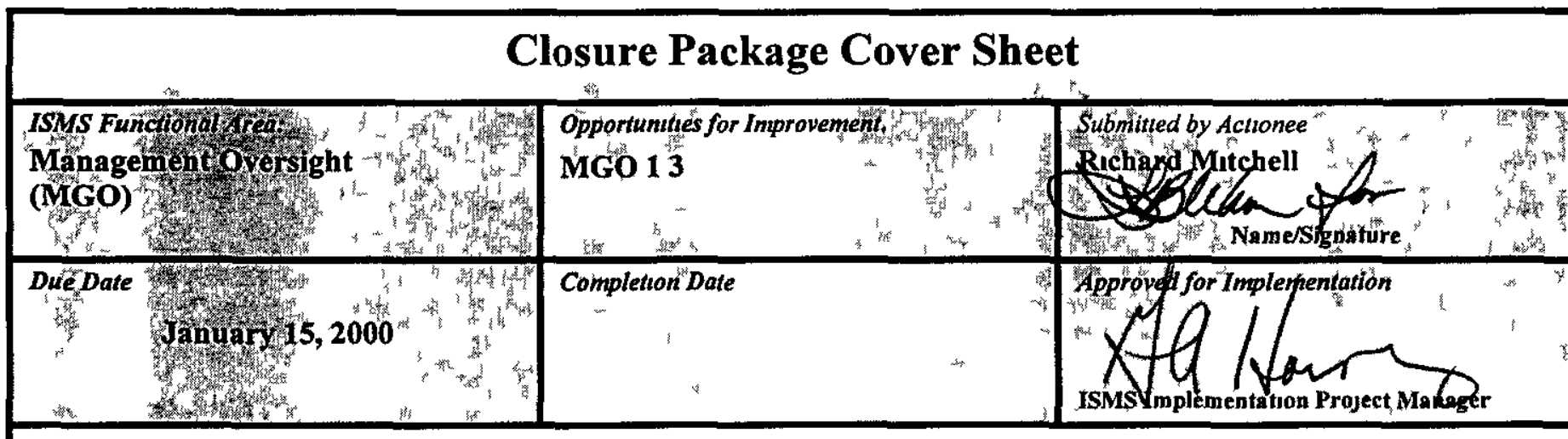

OPPORTUNITIES FOR IMPROVEMENT

Fac1lity-specific procedures have not been mapped to the FDH ISMS Plan

\section{Commitment}

Facility Specific procedures are mapped to ISMS through project level system descriptions This construct has been validated during the recent Project/Service verification assessments These linkages will be more clearly defined in the revised Management Plan (HNF-MP-001) and ISM System Description (HNF MP-003) In addition, this linkage will be tested during each Project/Service level Phase I Verification

\section{Subtask 01}

Distribute Verification lessons Learned to the Projects and Service Providers (Complete)

\section{Subtask 02}

Revise the PHMC ISMS verification strategy and schedule to ensure that the criteria for Project verifications include reviews as applicable of project/facility process and procedure links to the FDH ISMSD and that Projects/Service providers are required to develop ISM System Descriptions that link to the FH ISM System Description

\section{Subtask 03}

Revise PHMC verification schedule to be consistent w th the new project structure

\section{Acceptance Criteria}

Note Approval of this closure package and closure package MGO 1 1, MGO 12 , meets the criteria for Performance Incentive Item 1 B 2 as documented in Contract Number DE AC06-RL13200 M090

\section{Valıdation}

The following evidence (etter number reports etc) has been reviewed and are included in the closure package to validate the accuracy and completeness of the commitment

To be completed 
HNF-4554, Rev 3

1.9

\begin{tabular}{|c|c|c|c|c|}
\hline \multicolumn{5}{|c|}{ Closure Package Cover Sheet } \\
\hline $\begin{array}{l}\text { ISMS Functional Area } \\
\text { Management Oversight } \\
\text { (MGO) }\end{array}$ & 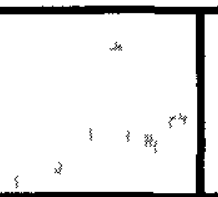 & \multicolumn{3}{|c|}{$\begin{array}{l}\text { Op̈portunties for Improvement w , } \\
\text { MGO } 13 \\
1\end{array}$} \\
\hline Why & 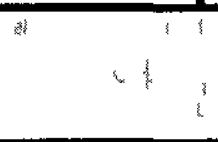 & Clos & Actions & 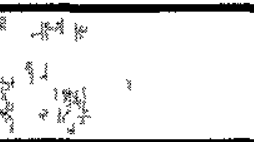 \\
\hline Submitted by & & & Date & \\
\hline $\begin{array}{l}\text { Concurrence By } \\
\text { ISMS Implementation Project }\end{array}$ & & & Date & \\
\hline Date Received & Date Validatec & & Date Approved by DOE & DTS Cross Reference \\
\hline
\end{tabular}




\section{Closure Package Cover Sheet}

\begin{tabular}{|l|l|l|}
\hline $\begin{array}{l}\text { ISMS Functonal Area } \\
\text { Radiological Controls } \\
\text { (SME-RP) }\end{array}$ & $\begin{array}{l}\text { Opporiunties for Improvement } \\
\text { SME-RP 2 }\end{array}$ & $\begin{array}{l}\text { Submitted by Actionee } \\
\mathrm{R} \text { N1 }\end{array}$ \\
\hline Due Date & Completion Date & Approved for Implementation \\
\hline
\end{tabular}

\section{OPPORTUNITIES FOR IMPROVEMENT}

Radıological controls and use of ALARA practices are not integrated and needs to be established in the FDH Operations and Maintenance Program procedures

\section{Commitment}

Evaluate and modify as necessary the Operations and Maintenance functional area procedures to ensure that radiological controls and ALARA practices are adequately integrated and represented

\section{Subtask 01}

The FDH Radiation Piotection group will review the procedures in the PHMS Operations and Maintenance functional areas and make recommendations for incorporation of Radiological considerations into these procedures

\section{Subtask 02}

Revise the Operations and Mantenance procedure review process to ensure RP has an opportunity to revieu proposed revisions to Operations and Maintenance procedures

\section{Subtask 03}

Incorporate modifications to the following HNF PROs

$\begin{array}{lll}\text { HNF PRO 696 } & \text { HNF PRO 489 } & \text { HNF PRO } 473 \\ \text { HNF PRO 1794 } & \text { HNF PRO 490 } & \text { HNF PRO 072 }\end{array}$

\section{Acceptance Criteri?}

Procedure changes for procedures listed in Subtask 03 approved

\section{Validation}

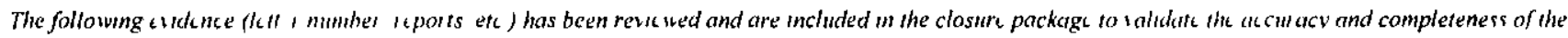
commiment

To be completed 
HNF-4554 ReV 3

1 - 11

\section{Closure Package Cover Sheet}

ISMS Functional Area

Radıological Controls

(SME-RP)
Opportunities for Improventent

SME-RP 2
Submutted by Actionee

$\mathbf{R} \mathbf{N} \mathbf{I}$

Vame/Stgnature

\section{Closure Actions}

Submutted by

Date

Concurrence By

Date

ISMS Implementation Pıojcct

Date Recerved

Date Validated

Date Appioved by DOE

DTS Cross Reference 


\section{Closure Package Cover Sheet}

\begin{tabular}{|l|l|l|}
\hline $\begin{array}{l}\text { ISMS Functional Area } \\
\text { Environmental Protection } \\
\text { (SME-EP) }\end{array}$ & $\begin{array}{l}\text { Opportunttes for Improvement } \\
\text { SME EP-4 }\end{array}$ \\
\hline Jue Date & Completion Date \\
$\mathrm{R}$ Ni
\end{tabular}

\section{OPPORTUNITIES FOR IMPROVEMENT}

Environmental controls are not being adequately integrated within Operations and Maintenance FDH level policies and procedures

\section{Commitment}

Evaluate and modify as necessary the Operations and Maintenance functional area procedures to ensure that environmental controls and concerns are adequately represented

\section{Subtask 01}

The FDH Environmental and Regulation Senıor Technical Advisor will review the procedures in the PHMS Operations and Maintenance functional areas (PHMS) and make recommendations for incorporation of Environmental considerations into these procedures

\section{Subtask 02}

Revise the Operations and Maintenance procedure review process to ensure EP has an opportunity to review proposed revisions to Operations and Maintenance procedures

\section{Subtask 03}

Incorporate modifications to the following HNF PROs to ensure that Environmental considerations are adequately captures as appropriate
HNF PRO 1793
HNF PRO 696
HNF PRO 058
HNF PRO 1794
HNF PRO 229
HNF PRO 473

HNF PRO 474

HNF PRO 069

\section{Acceptance Criterı}

Procedure changes to procedures listed in Subtask 03 approved

\section{Validation}

The followng eidence (letur mub r reports etc) has been revwed and are included in the closurt package to aldate th accuract and completencss of the commiment

To be completed 


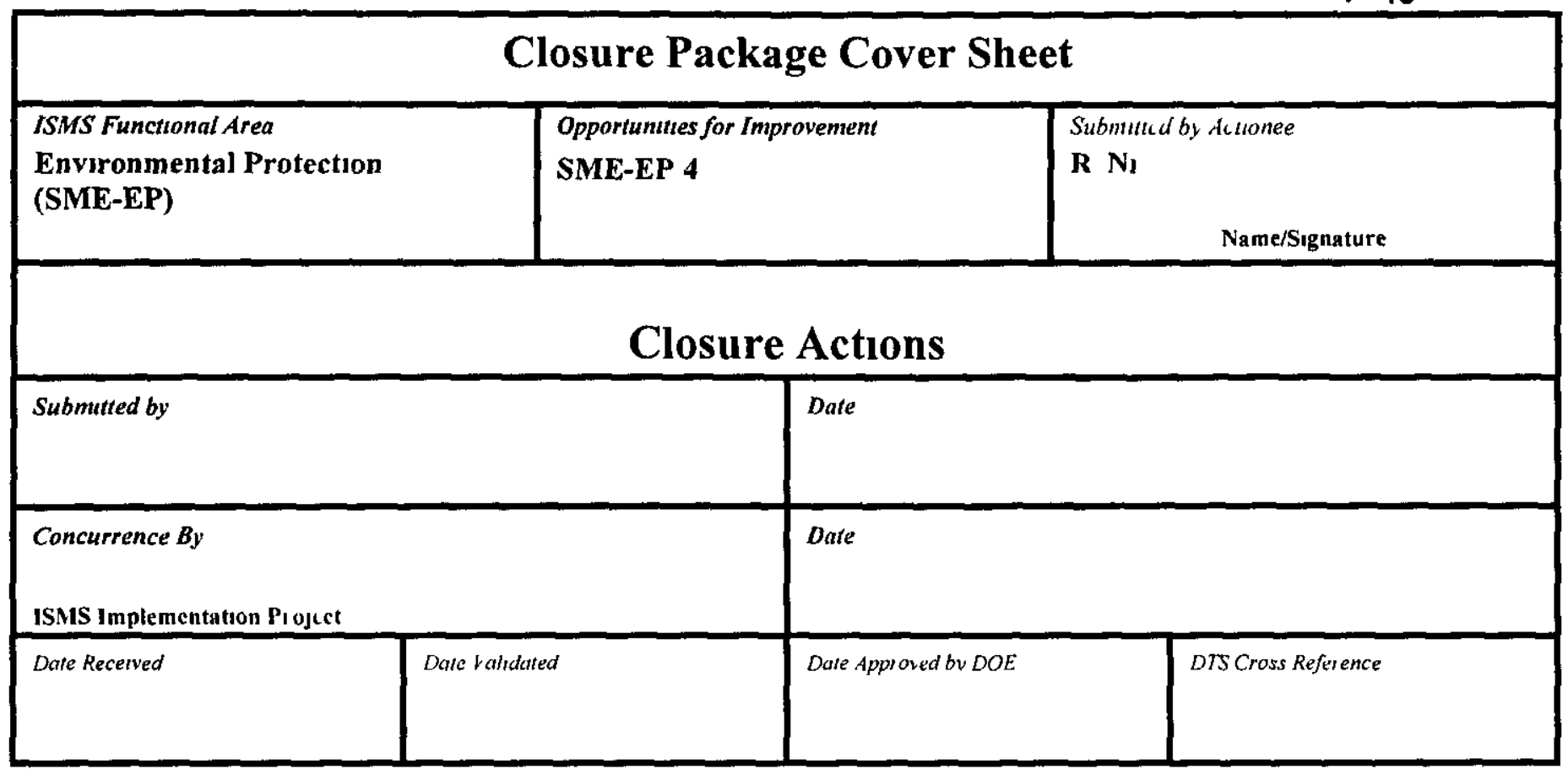


HNF-4554, Rev 3

\section{Attachment 2}

Fluor Hanford, Inc

Integrated Environment, Safety and Health

Management System

\section{IMPROVEMENT PLAN}

Consisting of $\mathbf{4 2}$ pages 


\section{INTRODUCTION}

Attachment 1 references the Phase 1 Verification of Fluor Hanford, Inc (FHI) Integrated Environment, Safety and Health Management System (ISMS), which was completed in October 1999 This verification resulted in both corrective actions (Attachment 1) and improvement opportunities This attachment provides the improvement plans and commitments by FHI to support continuous improvement of ISMS implementation at FHI

\section{FORMAT AND CONTENT OF IMPROVEMENT PLAN}

This attachment contains the 24 Opportunities for Improvement, and 2 Observations, which were identıfied in the Phase I Verification Report but do not require validation by RL prior to closure

Each Opportunity for Improvement and the associated commitments are documented using Closure Package Index/Cover Sheets These closure sheets provide

- Opportunity for Improvement statements

- ISMS functional area

- Lead Actionee

- Commitment statement

- Specific tasks, milestones and completion dates for those tasks

In addition, acceptance criteria are defined for each commitment These criteria will be used to support closure validation

Closure of commitments will require objective evidence to be presented to and approved by the validation authority for each Opportunity for Improvement 


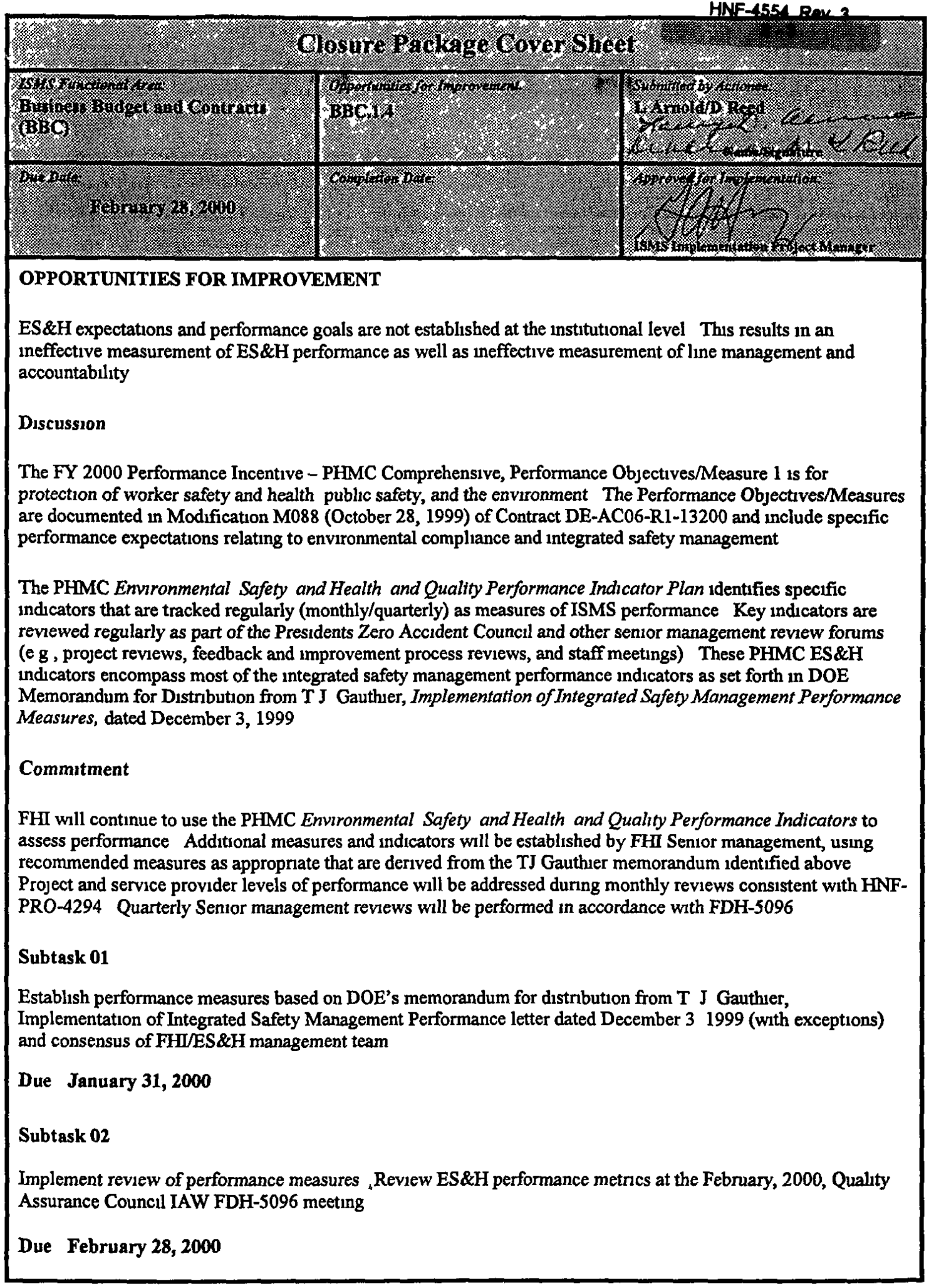




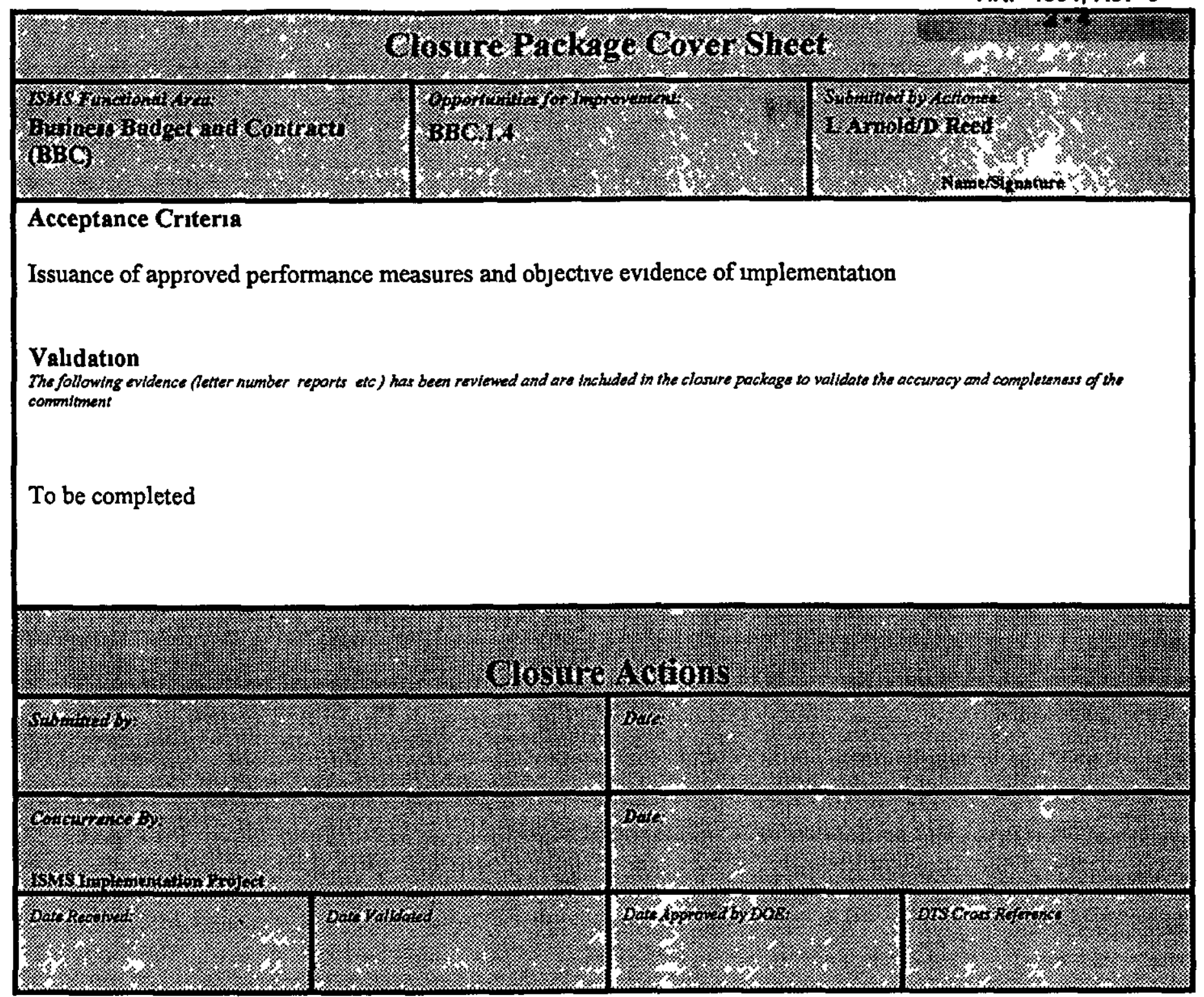




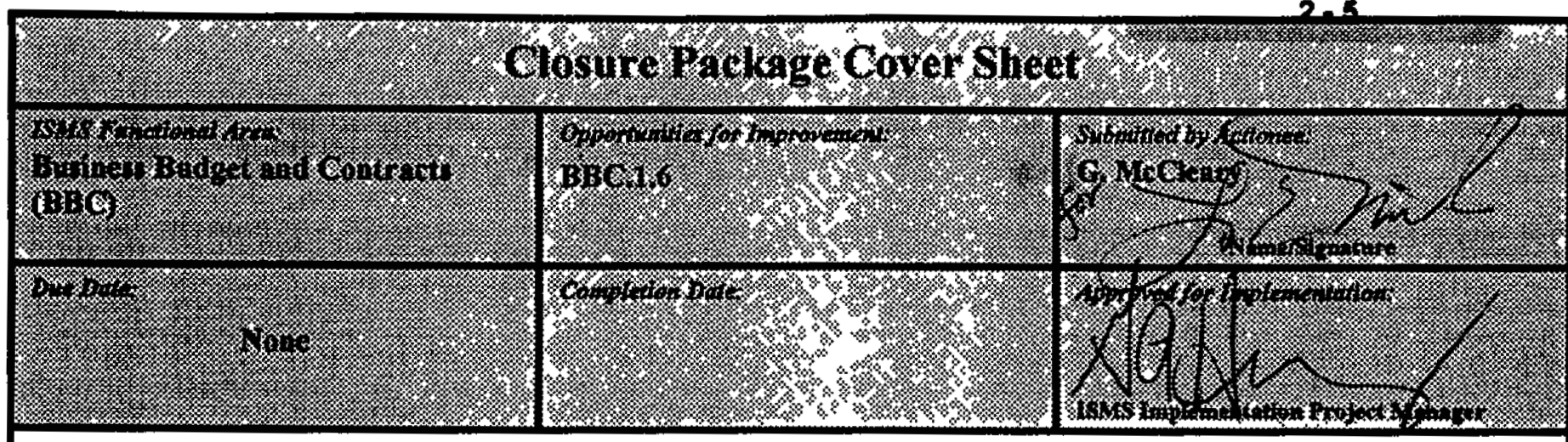

\section{OPPORTUNITIES FOR IMPROVEMENT}

The processes associated with pronitization are not fully documented Specifically there are no procedures that describe the processes used by the contractor to ensure a proper balance among competing prionties of the organization, reconciling internal and external conflicts The procedures should explicitly state how FDH ensures that safety is the top prionty in the allocation of resources

\section{Commitment}

FHI's pnontization process is fully documented by the following documentation The Mult1-Year Work Planning procedure (HNF-PRO-522), the Integrated Environmental Safety and Health Management System Plan (HNFMP-003) and Risk Management Plan (HNF-MP-005) Detaled guidance for classification of driver categones and other means of determining proper balances among competing pnonties are provided by FHI to the project via workshops (guidance documentation) and weekly telephone conference calls

FHI concludes that the processes associated with work scope prioritization are fully documented and that the procedure, plans and guidance documents addressed above are meetıng the cnterion

\section{Validation}

The following evidence (letter number reports etc) has been reviewed and are included in the closure package to validate the accuracy and completeness of the comoniment

\section{N/A}

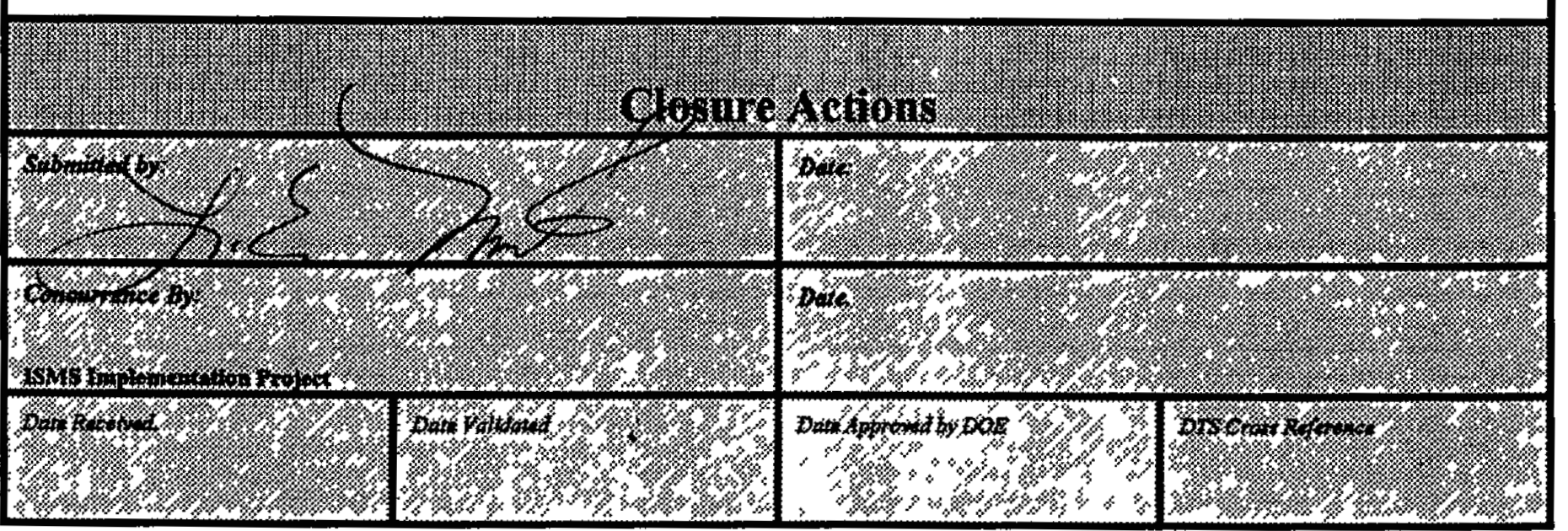




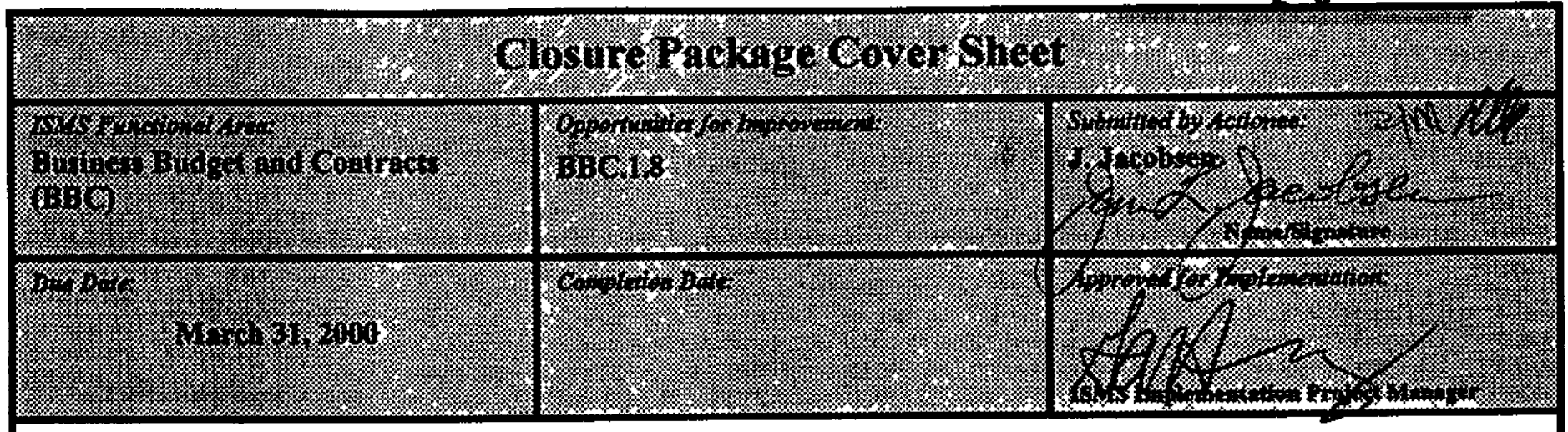

\section{OPPORTUNITIES FOR IMPROVEMENT}

HNF-PR0-706, PHMC Acquisition System Requirements does not mention flow down of ISMS requirements nor does it reference all of the procurement procedures that effect the acquisition system

\section{Commitment}

HNF-PRO-706 is currently being revised to incorporate numerous changes recently made in the PHMC As part of this revision, the ISMS DEAR clauses and their flow down requirements will be included, consistent with other referenced FAR and DEAR requirements This effort will be completed as part of the Management System Upgrade Project

\section{Subtask 01}

Issue a revised Acquisition Core Business Process

Due March 31, 2000

\section{Acceptance Criteria}

Verification of ISMS DEAR clauses flow down in the new Acquisition Core Business Process description

\section{Validation}

The following evidence (Netter number reports etc.) has been reviewed and are included in the closure package to validate the accuracy and completeness of the commitment

To be completed

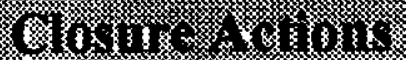

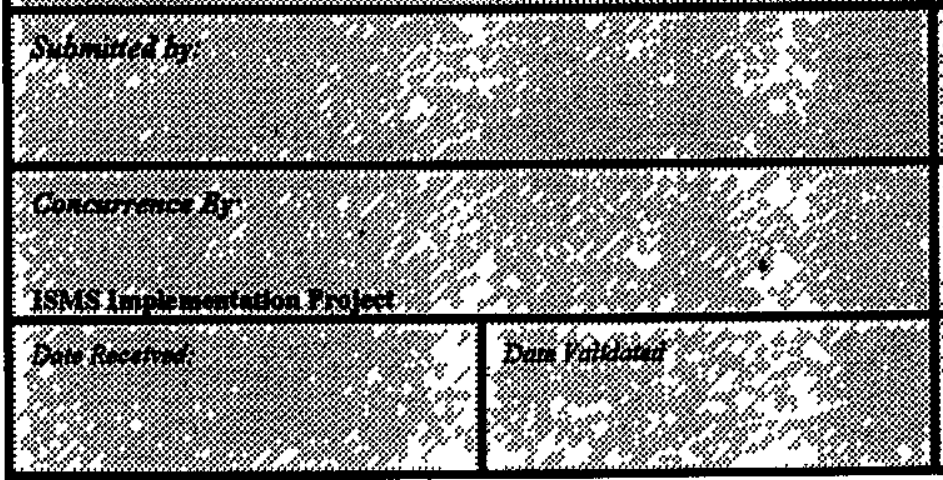

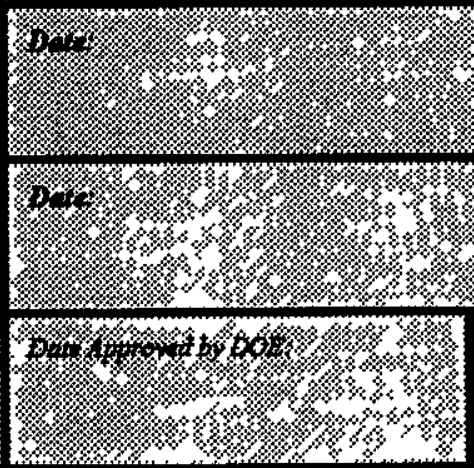




\section{Closure Package Cover Sheet}

\begin{tabular}{|c|c|c|}
\hline 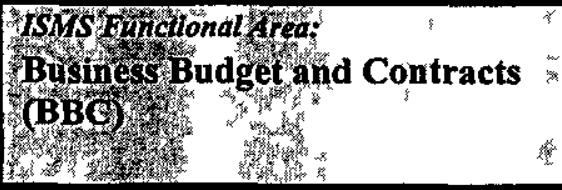 & 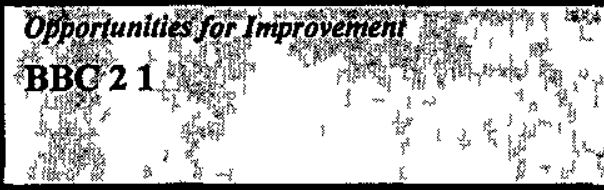 & 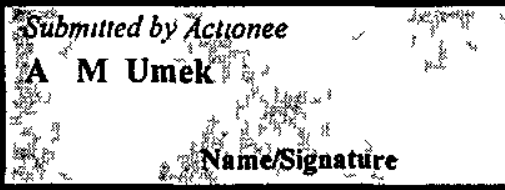 \\
\hline 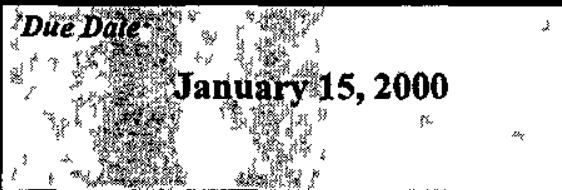 & Completion Dâ & Appropd for Imp ementation " \\
\hline
\end{tabular}

OPPORTUNITIES FOR IMPROVEMENT

The FDH procedures do not provide for secondary review at the FDH level for ensurnng that ES\&H support needs are adequately accounted for as part of work planning

\section{Commitment}

HNF MP-001 Rev 2 Management Plan, will define FHI s required method of operation including the application of work processes, practices systems and activitıes for performıng work per the PHMC The requirements contained in this document will be structured to achieve an appropriate level of operational consistency across FHI HNF-MP-001 will describe the process for establıshing priority work Those conditions presenting the greatest risk will be given the highest priority ES\&H input and review is essential to the evaluation and priority listing of work HNF-MP-001 also will require Project/Operations Execution Plans (PEPs) that include ISMS implementation and staffing needs FHI Project Directors will approve the PEPs Project Directors have responsibility and accountability for ensurıng regulatory compliance worker safety and environmental protection FHI ES\&H will support projects and operations in work planning and execution

\section{Subtask 01}

Revise and issue HNF MP-001

Due January 15, 2000

\section{Acceptance Criteria}

Revised HNF MP 001 issued by January 15, 2000, with an effectıve date and implementation strategy

\section{Valıdation}

The following evidence (fetter number reports etc) has been revtewed and are included in the closure package to validate the accuracy and completeness of the commitment

To be completed 
HNF-4554, Rev 3

2.8

\section{Closure Package Cover Sheet}

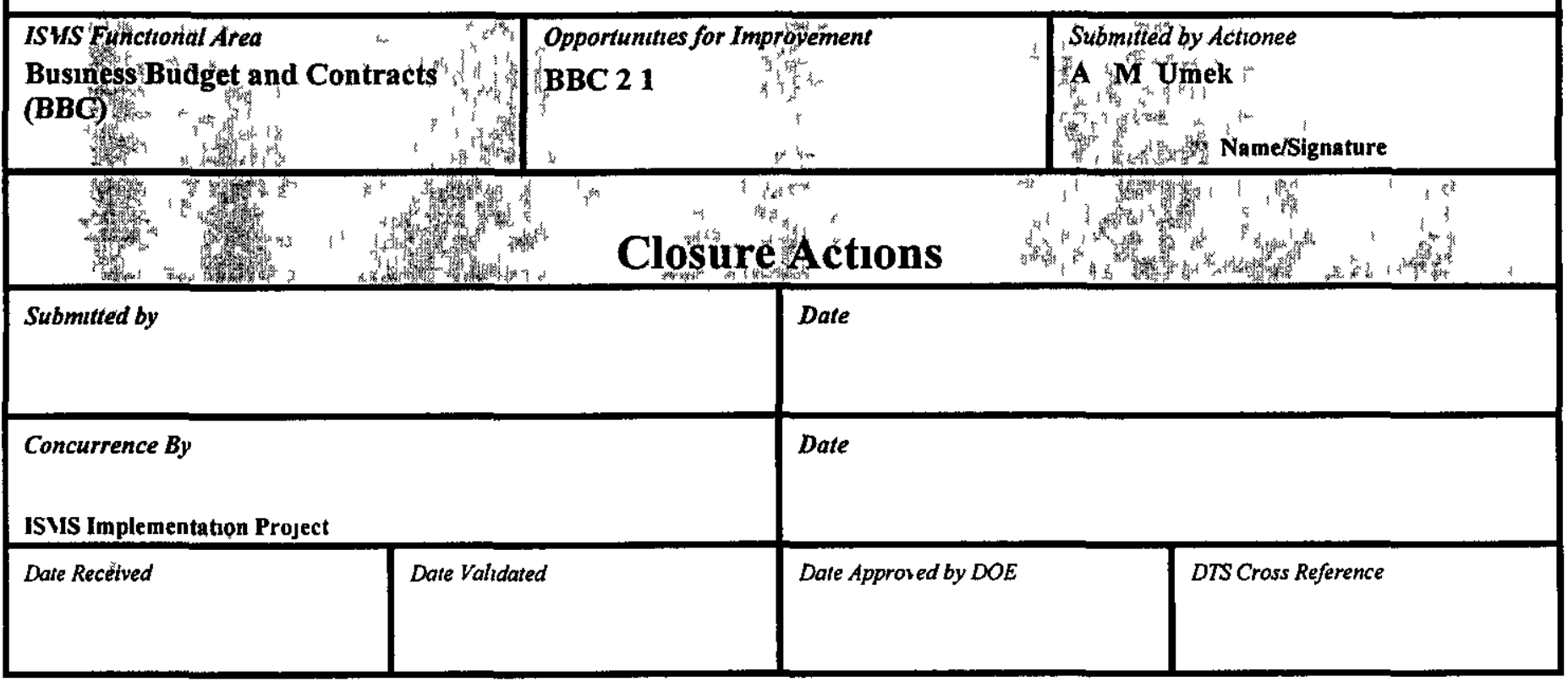




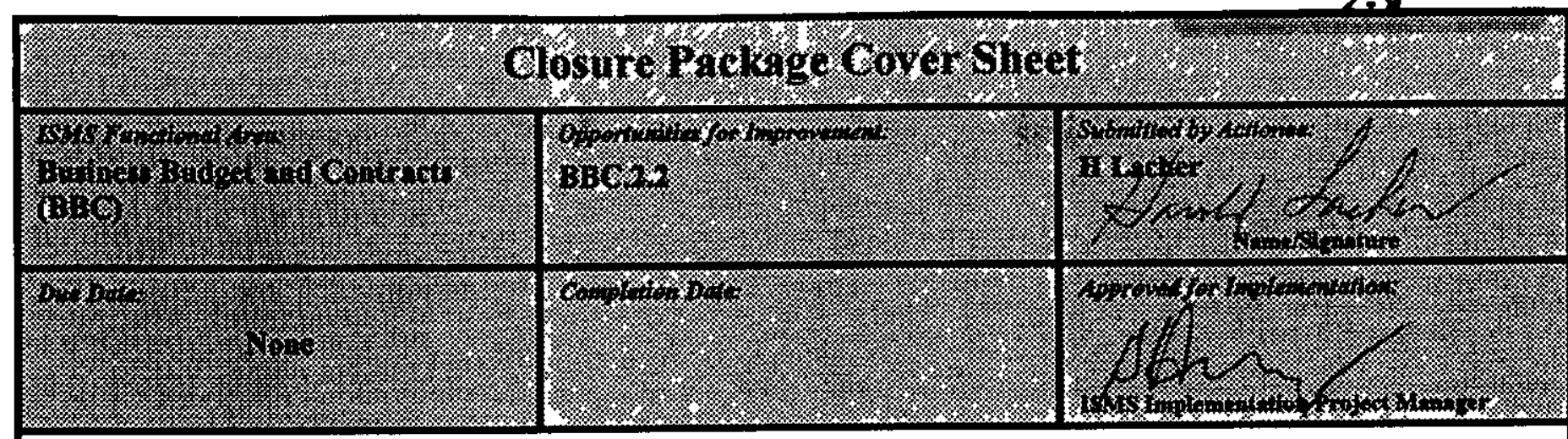

\section{OPPORTUNITIES FOR IMPROVEMENT}

ES\&H considerations need to be more visibly included in the HNF-PRO-054, Sharing of Fee with Employees to highlight its pronty

\section{Commitment}

The current wording in HNF-PRO-054, Sharing Fee with Employees meets the requirements of ISMS In the Phase I Verification Assessment Form, Objective BBC 2 indicates this criterion has been met "The contractor has recognition programs which recognize employees for accomplishments (including ES\&H) under which employees can be recognized by sharing in the contractor's fee "This is specifically written to address and reward employee efforts and achievements that support the company goals ES\&H are specifically included in company goals

No action required

\section{Acceptance Criteria}

None

\section{Validation}

The following evidence (etter number reports etc) has been reviewed and are included in the closure package to validate the accuracy and completeness of the commitment

To be completed

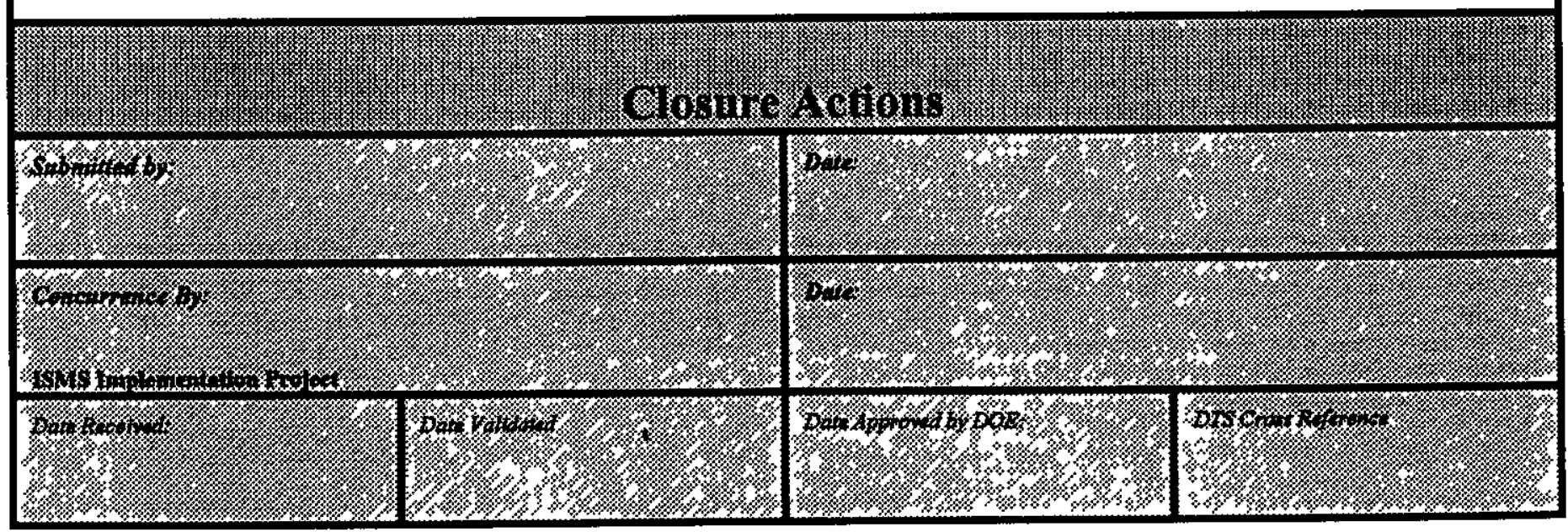




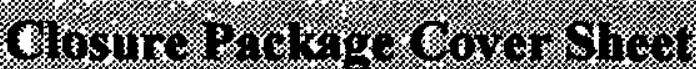

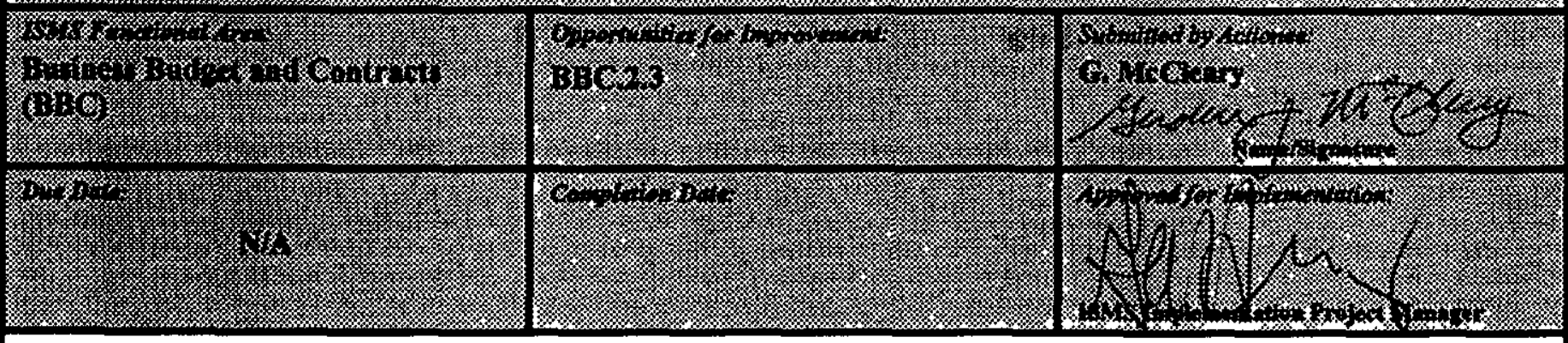

\section{OPPORTUNITIES FOR IMPROVEMENT}

The FDH procedures do not provide clear definition and/or critena for "tailored" hazard controls This lack of clear and consistent definition/criteria could adversely impact the cost-effectiveness of resources allocated to implementation of hazards controls

\section{Commitment}

The Job Hazard Analysis Procedure, HNF-PRO-079, Rev 4, provides a clear definition and/or cntena for "tallored" hazard controls This statement is supported under section 21 (Define Scope of Work) which states, "Define how and when to use job hazard analysis, applying a graded approach to implementation based on nsk and complexity Refer to the Risk and Complexity Determination screed of the Automated Job Hazard Analysis for risk and complexity critena "

Additionally, this procedure integrated ESH\&Q requirements into work planning and execution in accordance with the ISMS Plan (HNF-MP-003)

FDH concludes that the criteria is being met by the JHA procedure and that no further action is required

\section{Valıdation}

The following evidence (Netter number reports etc) has been reviewed and are included in the clasure package to validate the accuracy and completeness of the comonttment

Copy of HNF-PRO-079, with relevant text highlighted

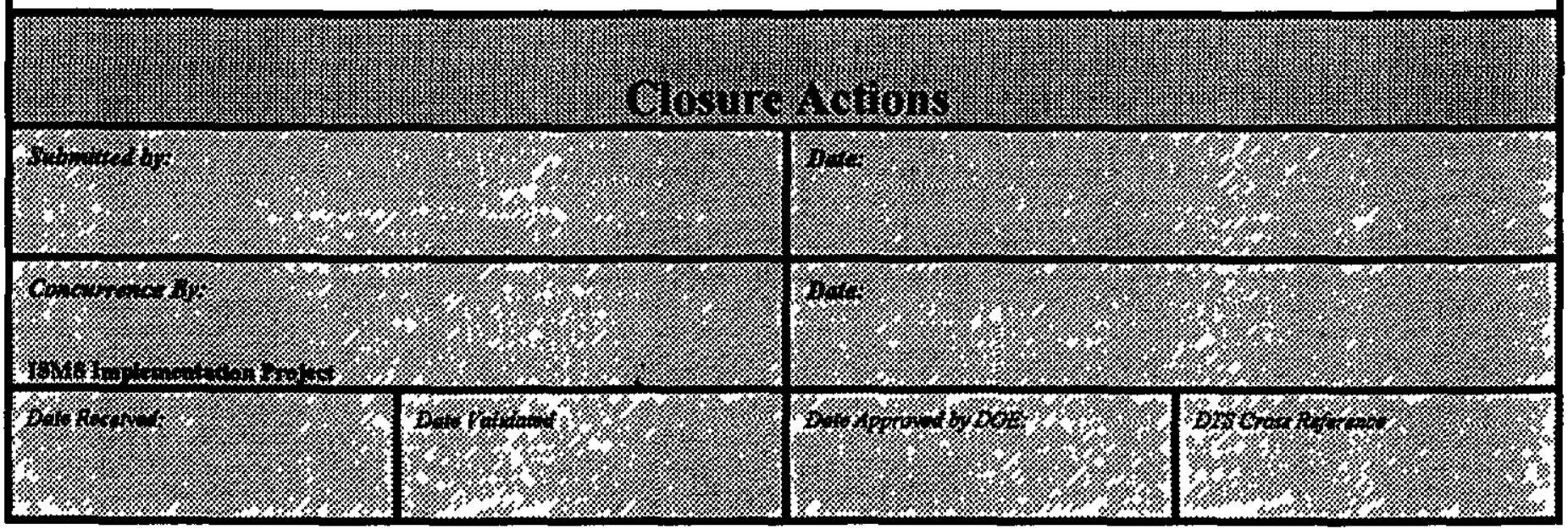




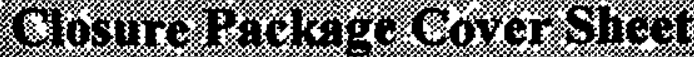

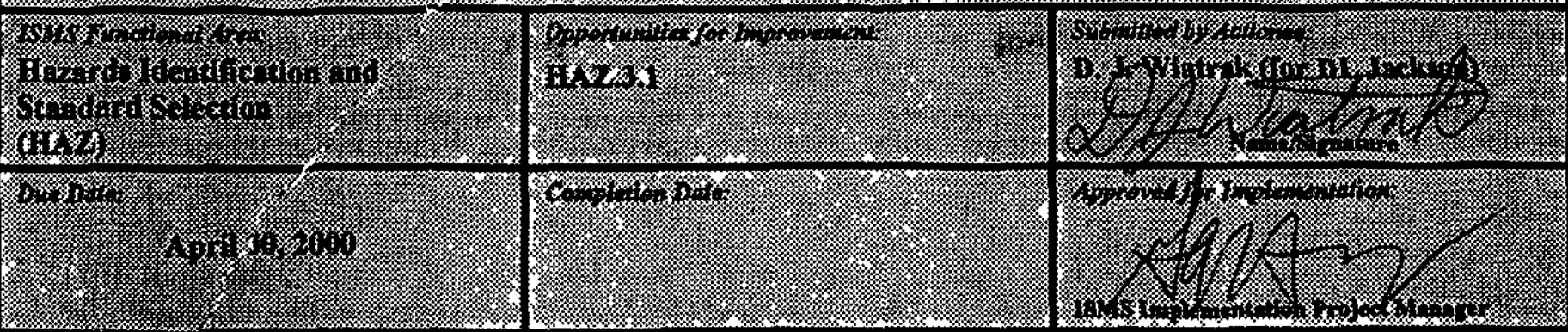

\section{OPPORTUNITIES FOR IMPROVEMENT}

HNF-PRO-079, Table 1 does not completely address the hazards and elımınate "gray" areas where the individual rust nuake the critical decision as to the "type" of hazard analysis

\section{Commitment}

HNF-PRO-079 will be revised to provide additional criteria for use by the Work Planner/Team in objectively analyzing the aspects of nisk and complexity for specific tasks to determine the level of job hazard analysis to be performed

\section{Subtask 01}

Reconvene the PHMC ConOps Enhanced Work Planning (EWP) Rusk and Complexity Subteam to serve as the workıng group in developing recommendations for evaluatıng nsk and complexity associated with work performance Due date 01/17/00, Actionee WH Meader

\section{Subtask 02}

Complete EWP workıng sessions, and submit written recommendations to DL Jackson, Director of FDH/OSH Due date 03/10/00, Actionee WH Meader

Subtask 03

Incorporate EWP recommendations into a Revision 6 draft of HNF-PRO-079 and process document for PHMS procedure comments Due date 03/30/00, Actionee DJ Wiatrak

Subtask 04

Disposition PHMC comment/mput, complete final editing, and obtain procedure approvals Due date 04/30/00, Actionee DJ Wiatrak

Acceptance Criteria

Submittal of HNF-PRO-079, revision 6 for PHMS publication Due date 04/30/00, Actionee DH Wiatrak

Validation

The following evidence (Netier number reports etc) has been reviewed and are included in the clasure package to validate the accuracy and completeness of the comonitment

To be completed 


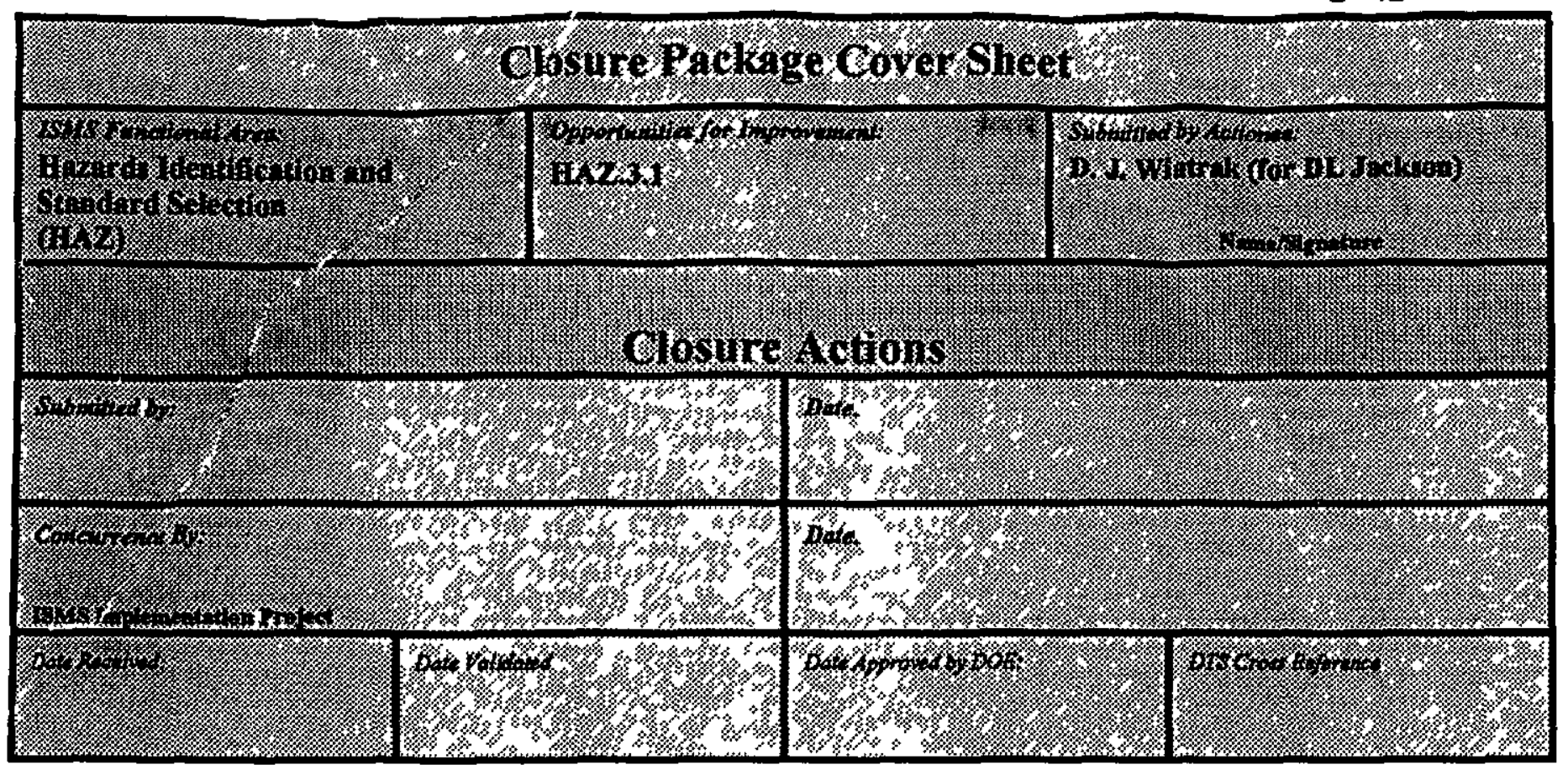




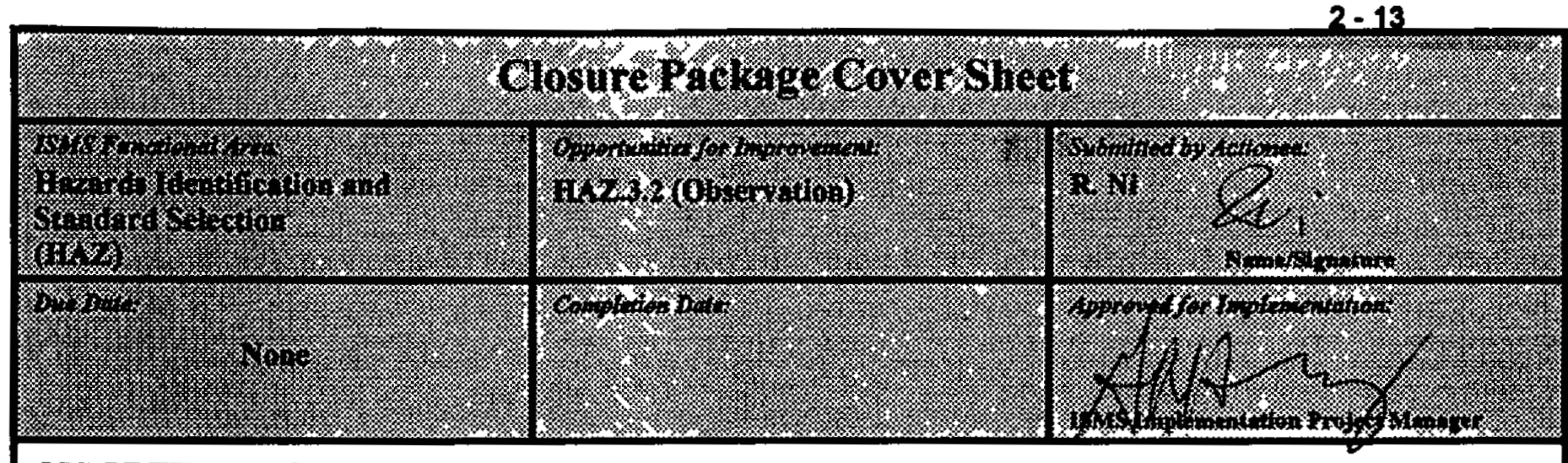

\section{OPPORTUNITIES FOR IMPROVEMENT}

In the HNF-PROs, the term "worker" is used very broadly and means anyone who does work, not just craftsmen who are inclusive in this term HNF-4361 reads such that one with a maintenance management background may interpret this high-level policy as refernng to craftsmen only During interviews FDH managers interpreted the policy as being inclusive of everyone doing work

\section{Commitment}

As reflected in the DOE observation, management and the organization were, in fact, interpreting the word "worker" as it was intended to be meant in the document No actions required

\section{Validation}

The following evidence (letter number reports etc) has been reviewed and are inchuded in the clasure package to validate the accuracy and completeness of the commitoment

No action required

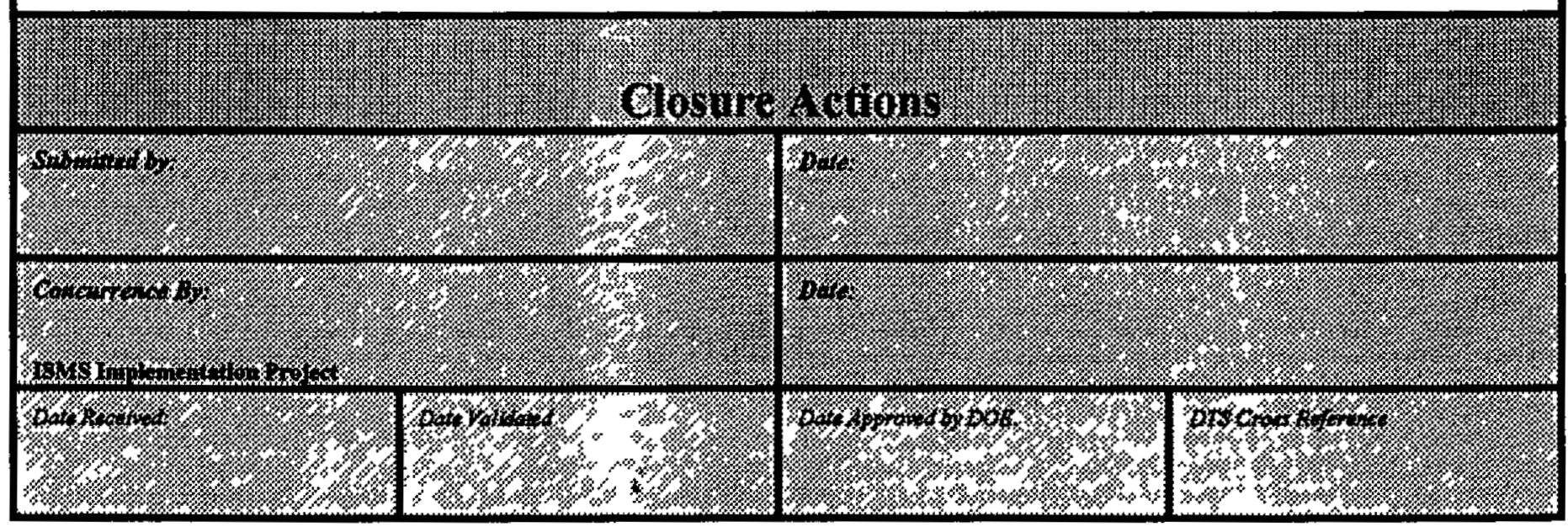




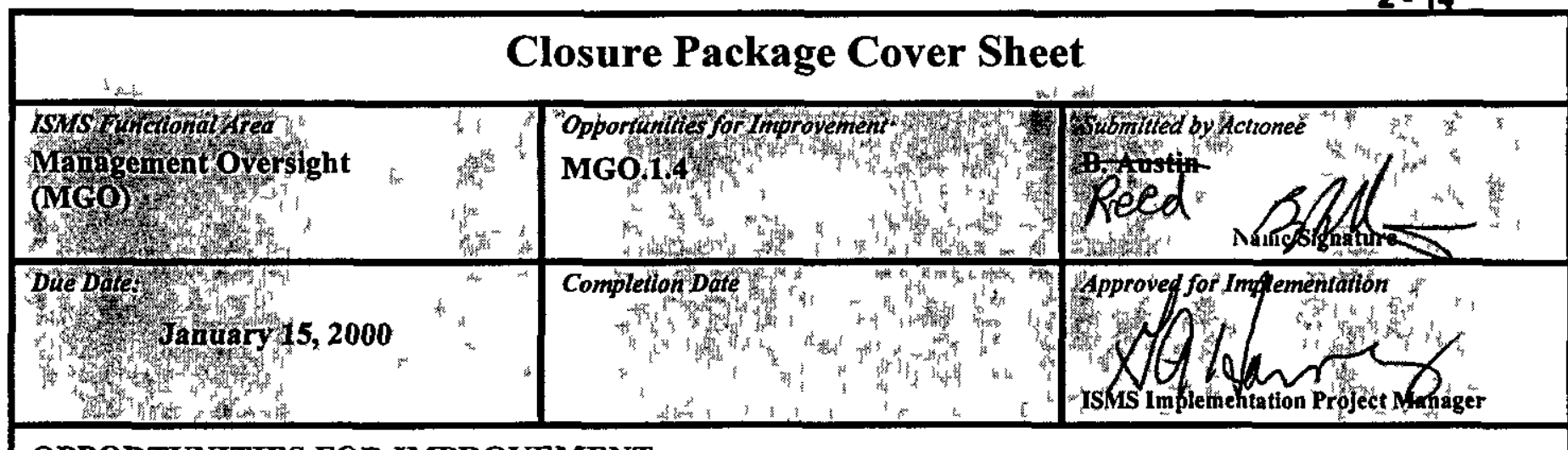

\section{OPPORTUNITIES FOR IMPROVEMENT}

The FDH ISMS Plan (HNF-MP 003) has not been updated as required

\section{Commitment}

HNF-MP-003 is being revised and will be issued by January 15, 2000 As part of the defined scope of work process, performance objectives and commitments are established annually through performance incentives In addition Core Functions six and seven ensures that the implementation of ISMS is reviewed by FHI Management and that the information from those reviews are used to prepare annual update reports as currently reflected in draft guidance

\section{Subtask 01}

Issue revision to HNF MP-003 by January 152000

\section{Acceptance Criteria}

Revision to HNF-MP 003 approved

\section{Valıdation}

The following evidence (etter number reports etc) has been reviewed and are included in the closure package to validate the accuracy and completeness of the commitment

To be completed

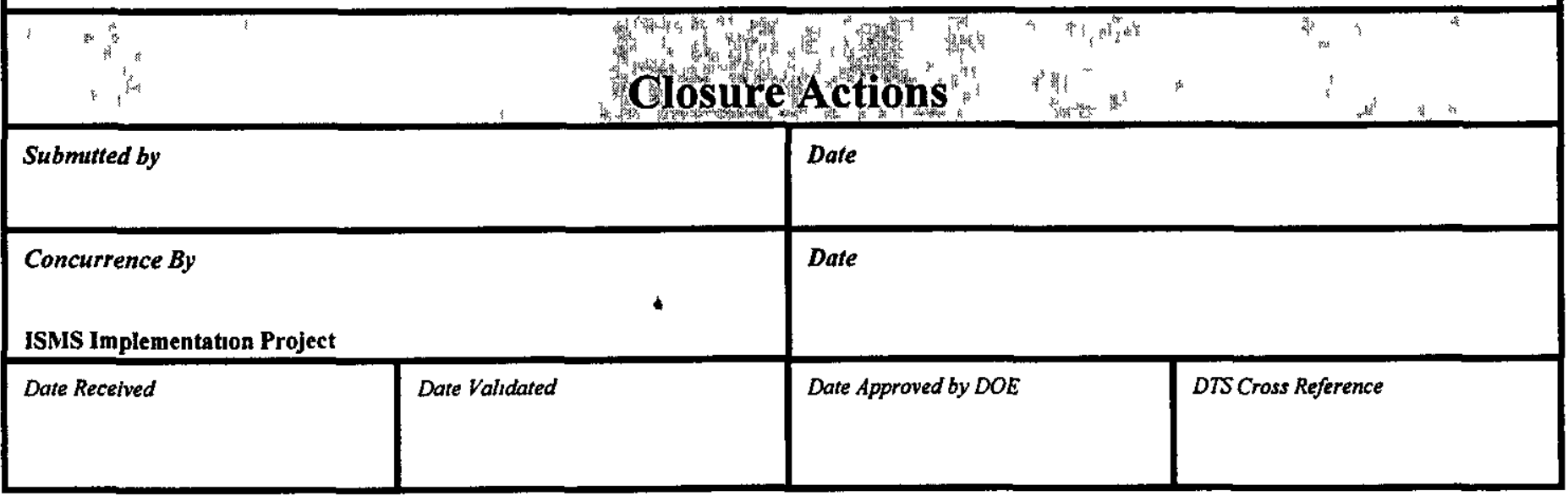




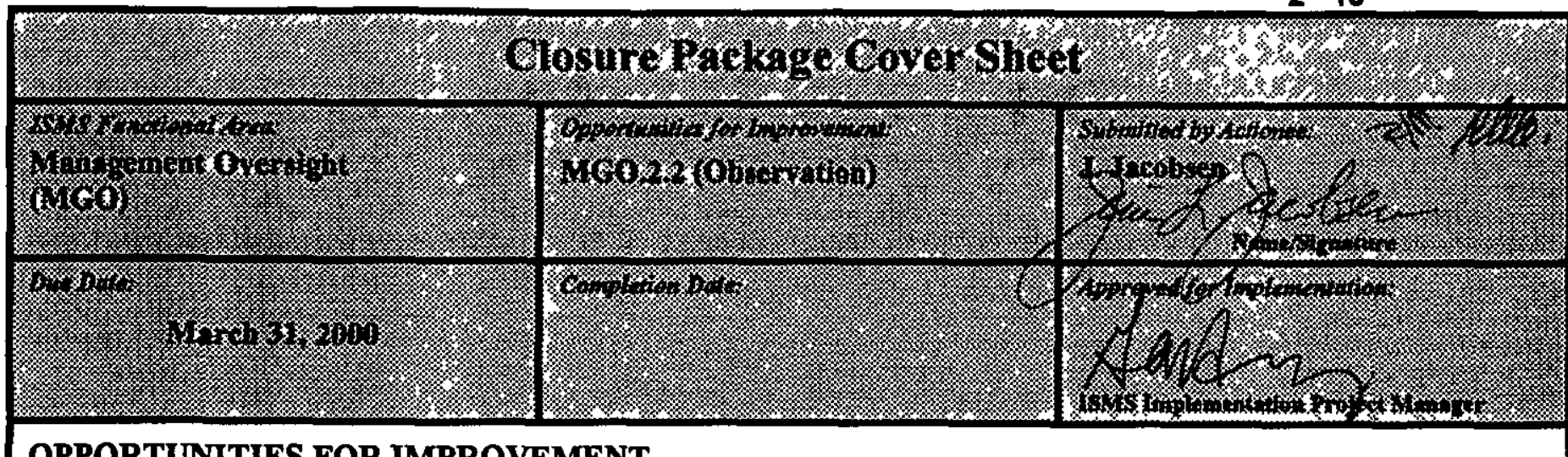

\section{OPPORTUNITIES FOR IMPROVEMENT}

HNF-PRO-074 currently does not include references to the ISMS Plan Prior to the expiration of HNF-MD-4821, the deficiency must be addressed in the permanent management system

\section{Commitment}

The Management System Upgrade Project has been developed and is in the process of being implemented This project will include changes to existing HNF-PROs that govern or provide guidance to the Acquisition Process These modifications to procedures will ensure that the appropnate DEAR and FAR clauses and ISMS flow down requirements are included

\section{Subtask 01}

Issue a revised Acquisition Core Busıness Process

Due March 31, 2000

\section{Acceptance Criteria}

Verification of ISMS DEAR clauses flow down in the new Acquisition Core Business Process description

\section{Validation}

The following evidence (etter number reports etc) has been reviewed and are included in the closure package to validate the accuracy and completeness of the commitment

To be completed

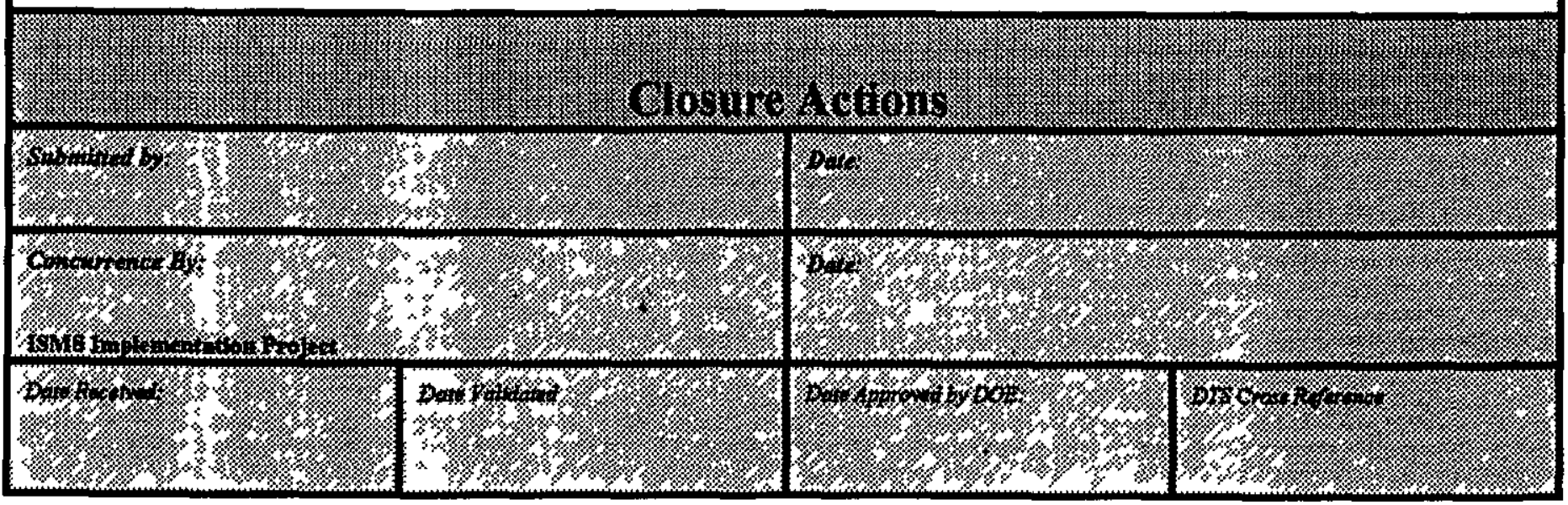




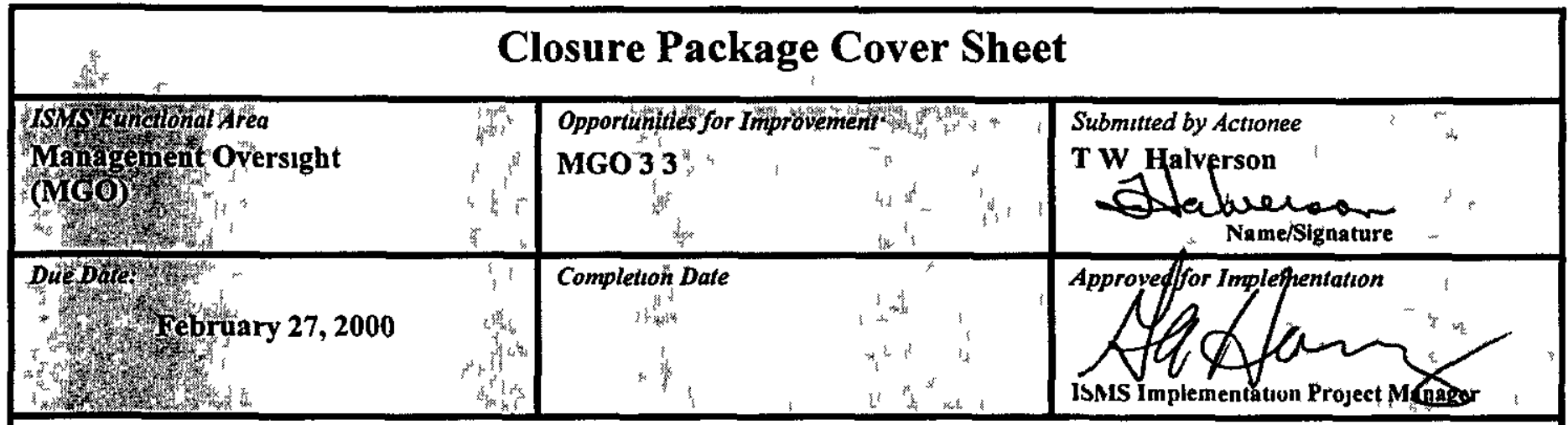

\section{OPPORTUNITIES FOR IMPROVEMENT}

The function of various centers of expertise committees etc is not recognized as a major element of the FDH feedback process nor legitımızed through integrated documentation

\section{Commitment}

The revision to HNF MP 001 will include information and guidance specific to the formation and approval authority of various committees and charters

\section{Subtask 01}

Issue HNF-MP-001

Due January 15, 2000

\section{Subtask 02}

Issue Policy statement which supports discussion provided in HNF MP 001

Due February 27, 2000

\section{Acceptance Criteria}

Approved HNF MP 001 and Policy statement

\section{Valıdation}

The following evidence (fetter number reports etc) has been reviewed and are included in the closure package to validate the accuracv and completeness of the commitment

To be completed

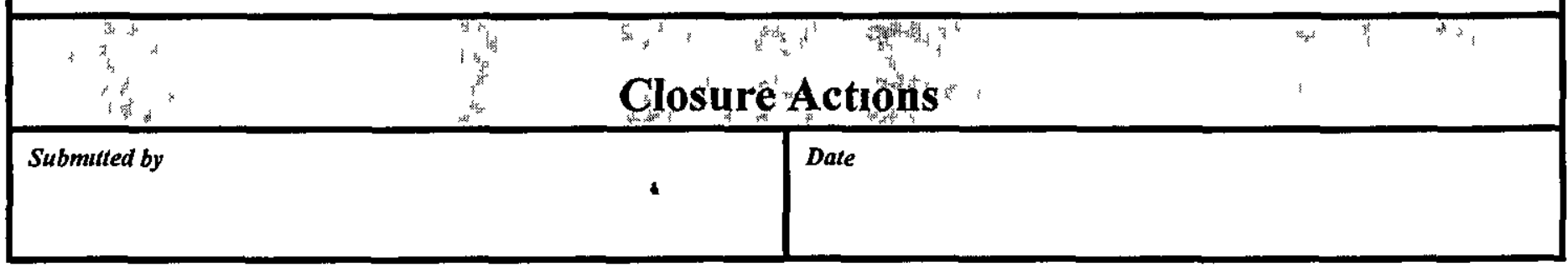




\begin{tabular}{|c|c|c|c|c|}
\hline 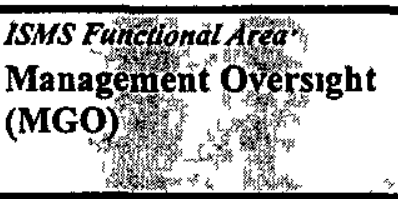 & 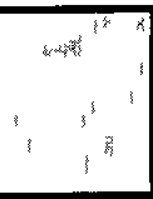 & $\begin{array}{l}\text { Opportumuties for Improvement } 4 \text {, } \\
\text { MGO } 3.3\end{array}$ & $\begin{array}{l}\text { 6ribmitted by Actronee } \\
\text { T W Halverson } \\
\text { W Hame/Signature }\end{array}$ & , \\
\hline $\begin{array}{l}\text { Concurrence By } \\
\text { ISMS Implementation Project }\end{array}$ & & Date & & \\
\hline Date Received & Date Validat & Date Approved by DOE & DTS Cross Reference & \\
\hline
\end{tabular}




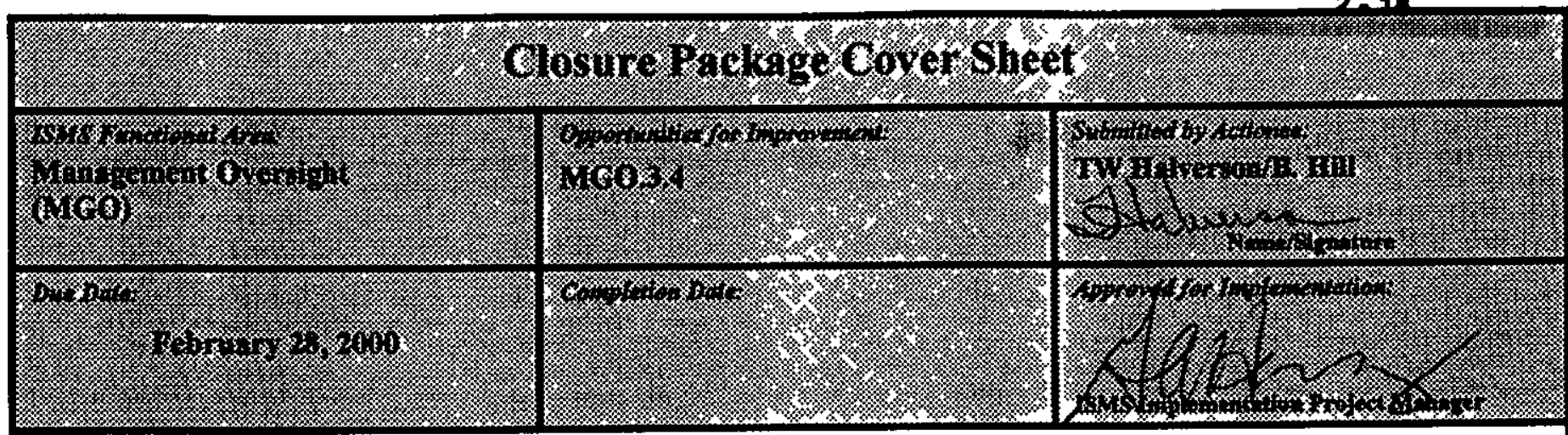

\section{OPPORTUNITIES FOR IMPROVEMENT}

Feedback processes are not formally integrated with the Business, Budget, and Project systems

\section{Commitment}

This issue is linked to MGO 36 and all actions described in that closure sheet will satisfy closure for this Opportunity for Improvement

\section{Subtask 01}

See MGO 36

\section{Acceptance Criteria}

See MGO 36

\section{Validation}

The following evidence (letter number reports etc) has been reviewed and are included in the closure package to validate the accuracy and completeness of the commitment

To be completed

\section{Otovire tations}

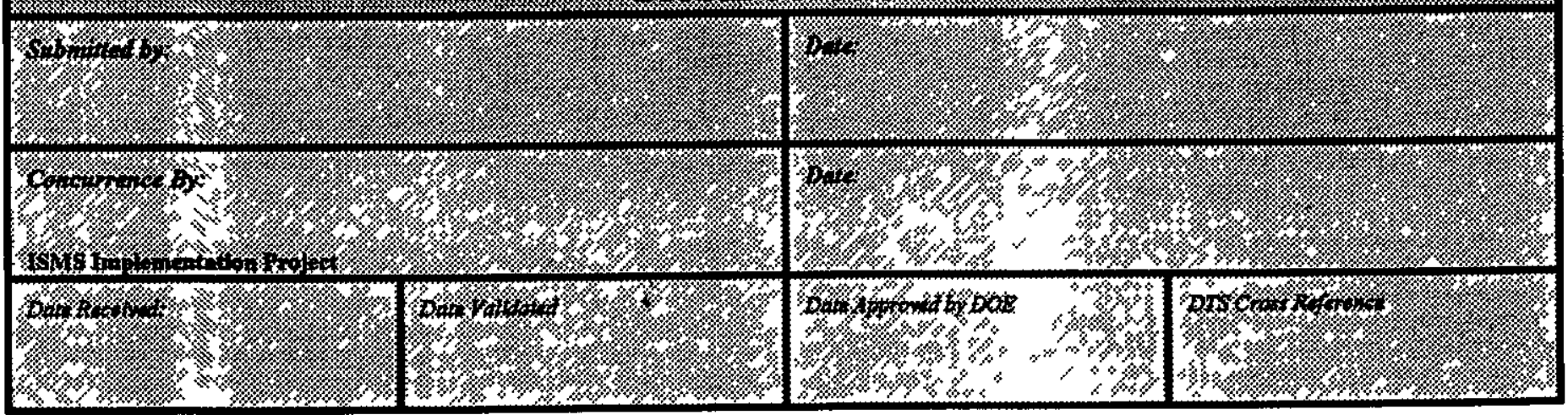




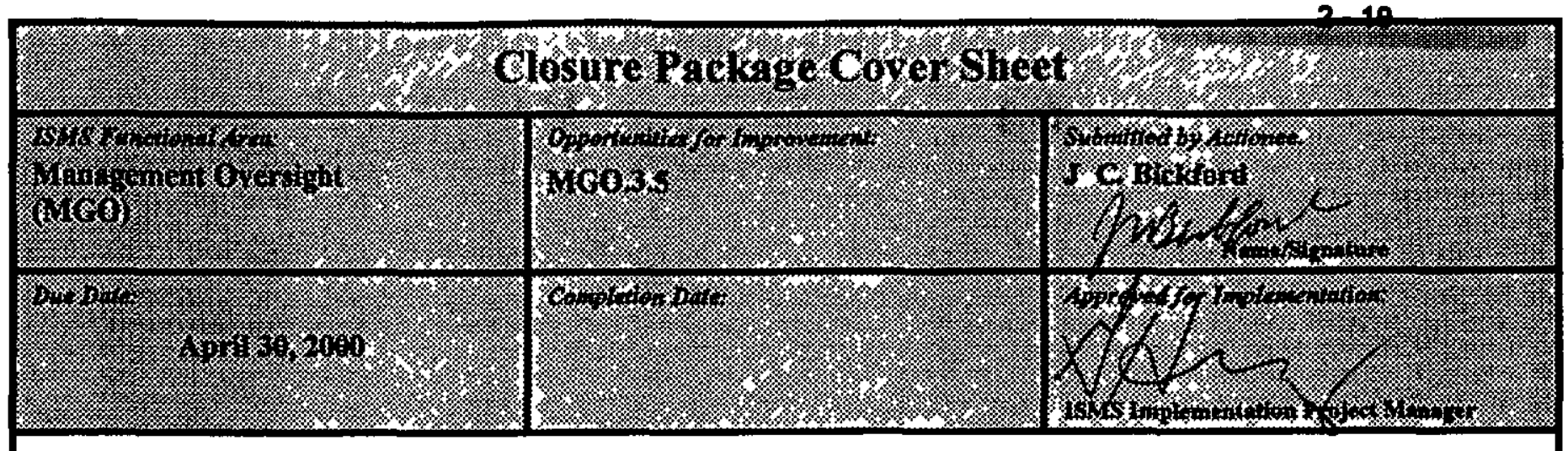

\section{OPPORTUNITIES FOR IMPROVEMENT}

Lessons learned procedures do not provide an expectation on required input or the appropriate point of application or follow through

\section{Commitment}

Lessons learned are processed according to the guidelınes in HNF-PRO-067, Managing Lessons Learned That procedure gives examples of external sources that feed the process but does not provide an expectation of what onsite activities such as AHJA, post-job reviews, and mockup training, provide inputs into the lessons learned system Neither does it provide a follow up mechanism for ensunng that appropnate managers apply the lessons learned to their activities

The PHMC Lessons Learned Coordınator, workıng with project representatıves, will develop a process to provide appropriate feedback from facility/project managers and follow-up mechanisms to ensure actions ansing from lessons learned are tracked appropnately The resulting processes along with appropnate direction for onsite actıvities feeding into the lessons learned system, will be incorporated into HNF-PRO-067 during the next normal revision

\section{Subtask 01}

Collect examples of effective feedback and tracking processes/systems from other DOE sites

\section{(Complete)}

\section{Subtask 02}

Convene a forum of lessons learned Points-Of-Contact to modify the present lessons learned process to include acceptable feedback and tracking mechanısms incorporatıng benchmark examples from other DOE sites

(Due January 30, 2000)

\section{Subtask 03}

Process revision to HNF-PRO-067 through the PHMS review and approval cycle

(Due April 30, 2000)

\section{Acceptance Criteria}

Revision to HNF-PRO-067 approved which includes a feedback and tracking process and guidance for onsite activities to feed the lessons leamed process 


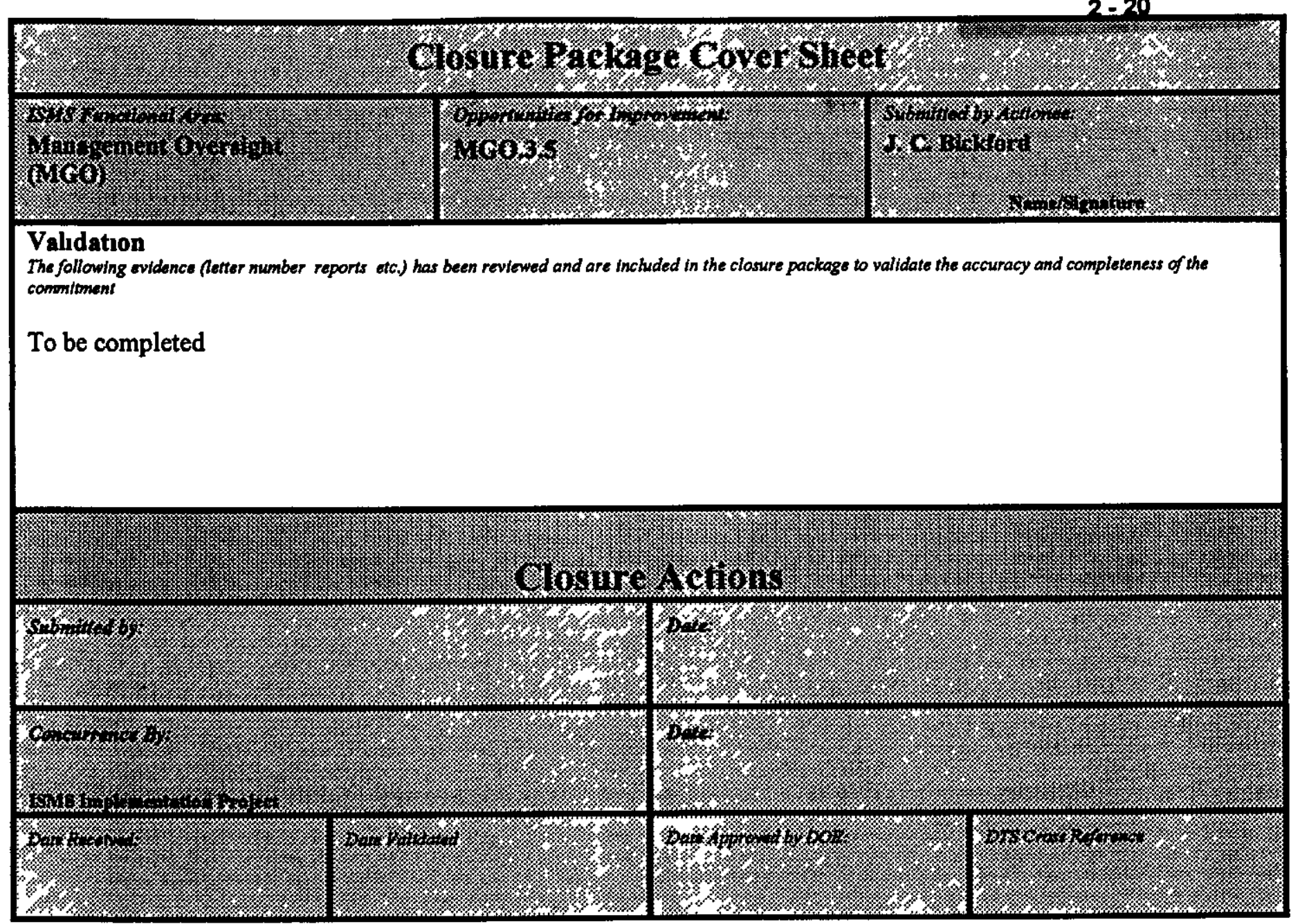




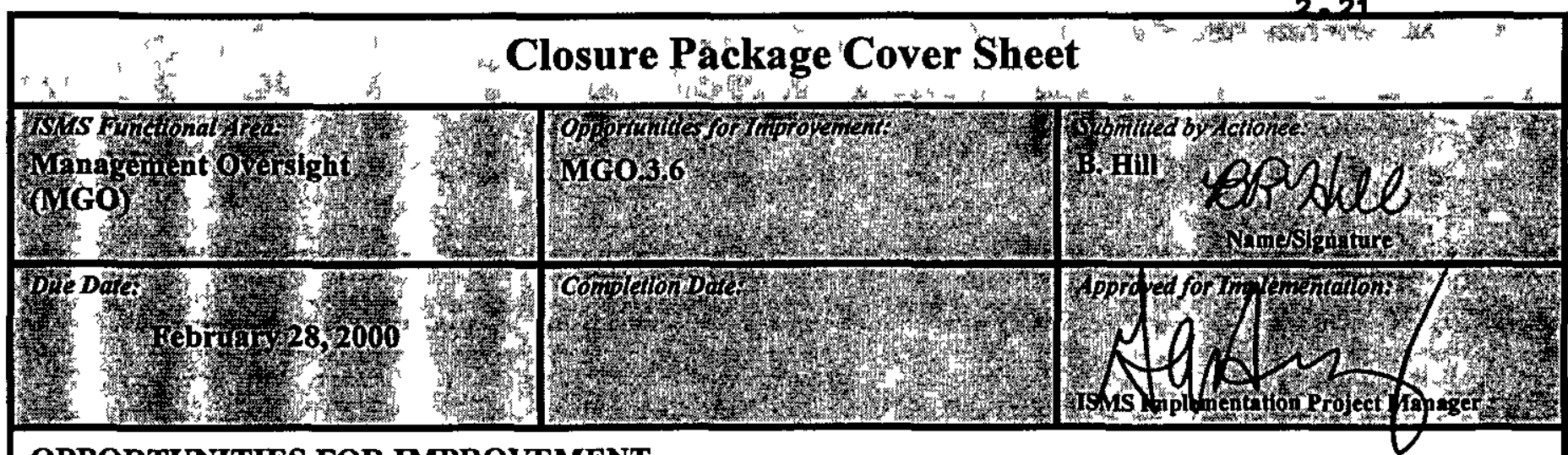

OPPORTUNITIES FOR IMPROVEMENT

Procedures governing feedback are numerous and not fully integrated

\section{Commitment}

FDH-5096 Feedback and Improvement Process provides a process for reviewıng screenıng, and analyzıng input data to identify areas for improvement and site initiatives and, as applicable, to establish operational performance goals This procedure requires that input be received at least quarterly from the various feedback mechanisms such as the Management Assessment Program, FEB reports, lessons Learned, CAM/DTS, and ESH\&Q established performance metrics The CAMS incorporates analysis of multiple other feedback systems such as Radiological Problem Reports, DNFSB reports and ORPS reports This procedure provides the integration of all of the above feedback mechanisms

\section{Subtask 01}

- Develop Feedback and Improvement Procedure

- Assure multıple sources of feedback are incorporated/integrated

- Review/obtain feedback of Senıor Management in President's Quality Council

Complete, objective evidence included

\section{Subtask 02}

- Develop proposed grouping for database template for Feedback and Improvement Process

- Review/Obtain feedback of Senıor management in Presıdent's Quality Council

Due Proposed grouping complete, objective evidence included, minutes due 1/7/00

\section{Subtask 03}

- Complete initial report for FY $20001^{\text {st }}$ Qtr by February 282000 for review/comment/action in President's Quality Council

Due February 28, 2000 


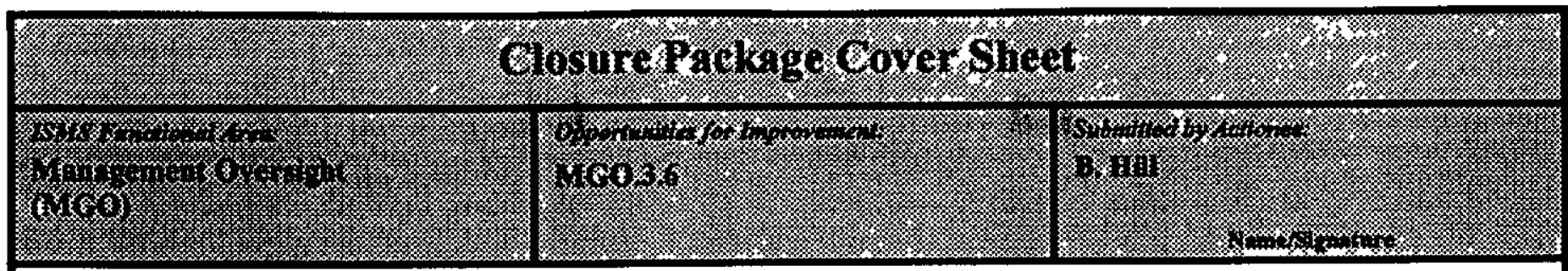

Acceptance Criteria

Subtask 01

- Signed off Feedback and Improvement procedure Feedback and Improvement Process FDH-5096 Rev 0 Attachment 1

- Feedback source document examples

1 Management Assessment Program quarterly report Attachment 2

2 Facilities Evaluation Board (FEB) reports Attachment 3, draft FEB schedule Attachment 4 FEB Procedure, FE1-1 Attachment 5

3 Lessons Learned, Lessons Learned Home Page Attachment 6

4 Environment, Safety and Health Quality, Operations Maintenance and other established performance matnces Attachment 7

5 Corrective Action Management (CAM)/Deficiency Tracking System (DTS) trending reports Attachment 8

- Minutes from October 281999 President's Quality Council Attachment 9

Subtask 02

- Documentation of proposed themes for grouping feedback and improvement key areas and Access database template Attachment 10

- Minutes from December 15, 1999 President's Quality council - Due 1/7/00

Subtask 03

- Initıal report for FY $20001^{\text {th }}$ quarter - Due 2/28/00

\section{Validation}

The following avdence (lester number reports ac) has been reviewed and are uncluded in the closure package to valudate the accuracy and complateness of the commument.

To be completed

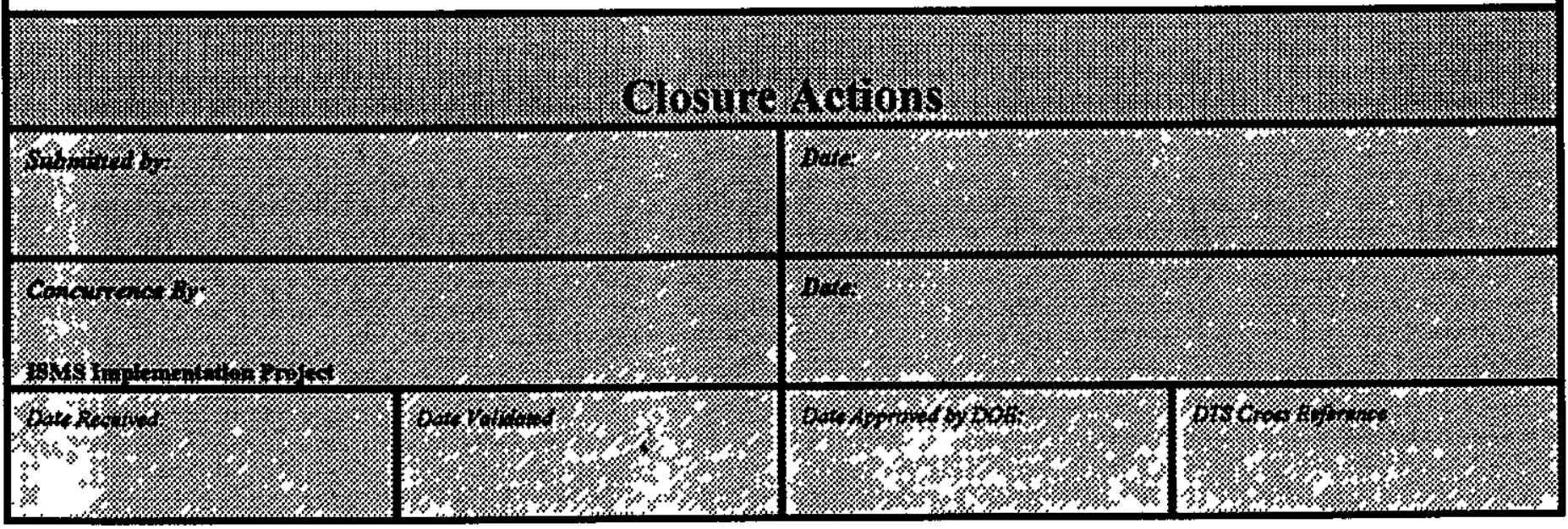




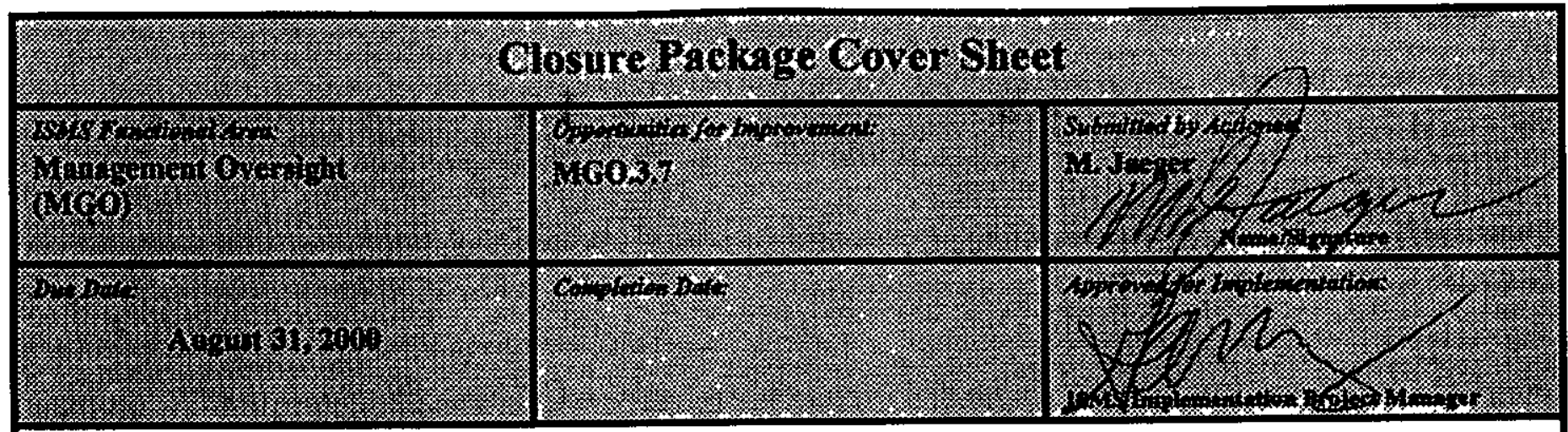

\section{OPPORTUNITIES FOR IMPROVEMENT}

The Automated Job Hazard Analysis program has not established a formal link between the post job reviews and the formal feedback mechanism, Lessons Learned

\section{Commitment}

'Noteworthy Information/Lessons Learned ' database will be established within AJHA Information from the Post Job Reviews will be compiled within this database Additional explanatory information can also be added The database will have strong search capabilities and will be designed for convenient review durng the work planning process

Lessons learned information within this database can be viewed and retrieved by FDH lessons learned personnel for incorporation into the site-wide lessons learned site

\section{Subtask 01}

Design database

Due April 1, 2000

\section{Subtask 02}

Program designed database and create necessary links to site lessons learned database

Due July 31, 2000

\section{Subtask 03}

Test "Noteworthy Information/Lessons Leamed database and release into AJHA production

Due August 31, 2000

\section{Acceptance Criteria}

Successful release for "Noteworthy Information/Lessons Learned" database into the AJHA production

\section{Validation}

The following avidence (etter number reports efc.) has been reviewed and are inchuded in the clasure package to validate the accuracy and complateness of the commitment

To be completed 
HNF-4554 Rev 3

2- 24

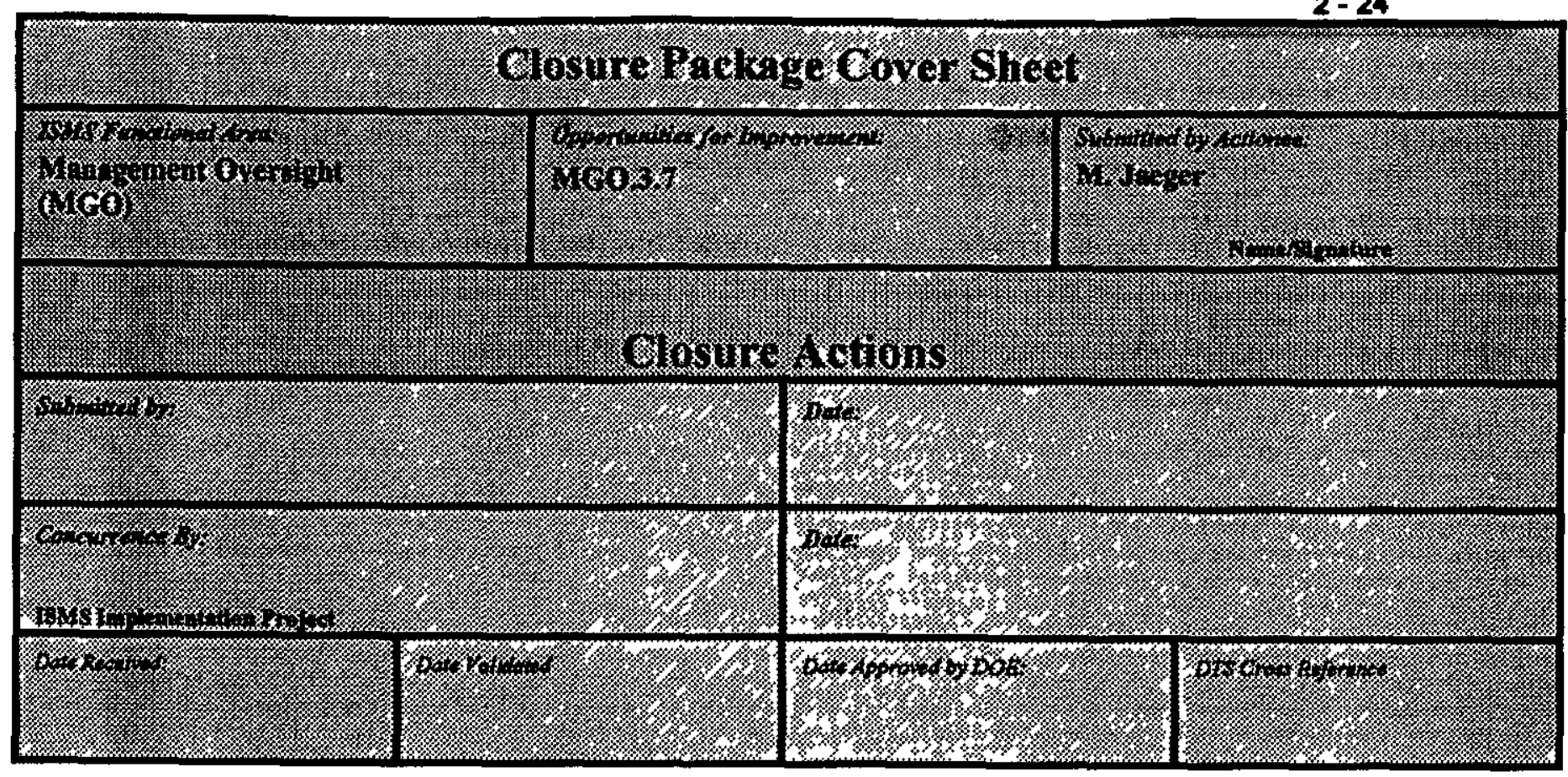




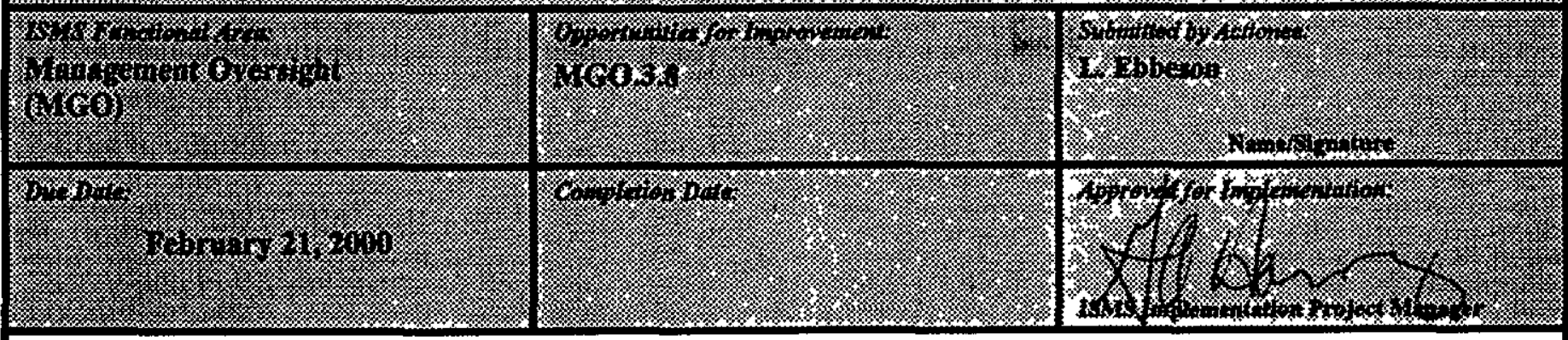

\section{OPPORTUNITIES FOR IMPROVEMENT}

Performance analysis and corrective action is not taken for events and conditions below the event level (1 e , NCRs, RPRs)

\section{Commitment}

There are many reportıng mechanısms (Non-Compliance Reports Radiological Problem Reports, etc) driven by several functional area processes and numerous source driven requirements There is currently no single established method to capture and analyze the aggregate data from these reporting mechanisms

The Management System Upgrade Project provides the disciplined process to identıfy and develop core processes that will address this issue

\section{Subtask 01}

The Management System Upgrade Project to develop an event reporting core business process that approprately incorporates the numerous reporting mechanisms and links with the feedback and improvement core process Deliver path forward and implementation schedule

Due date February 21, 2000

\section{Acceptance Criteria}

New process implemented

\section{Validation}

The following evidence (Retrer number reports afc) has been reviewed and are inchuded in the clantre package to validate the accuracy and complotenass of the commitment

To be completed

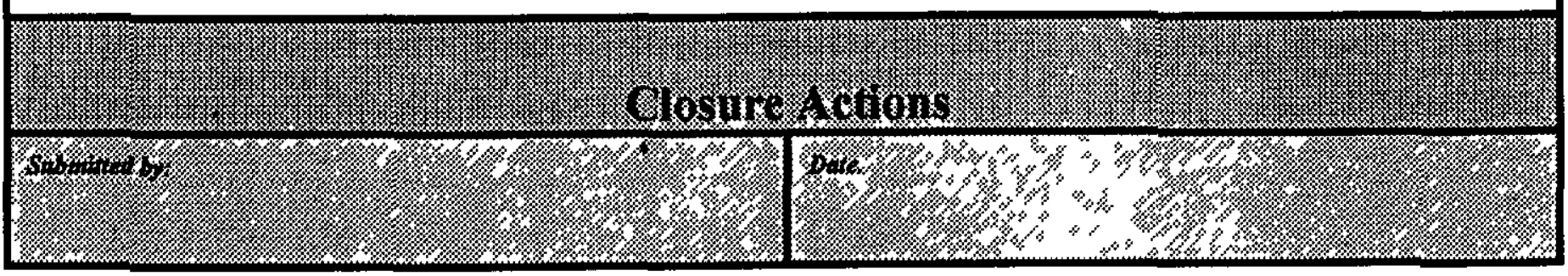


HNF-4554, Rev 3

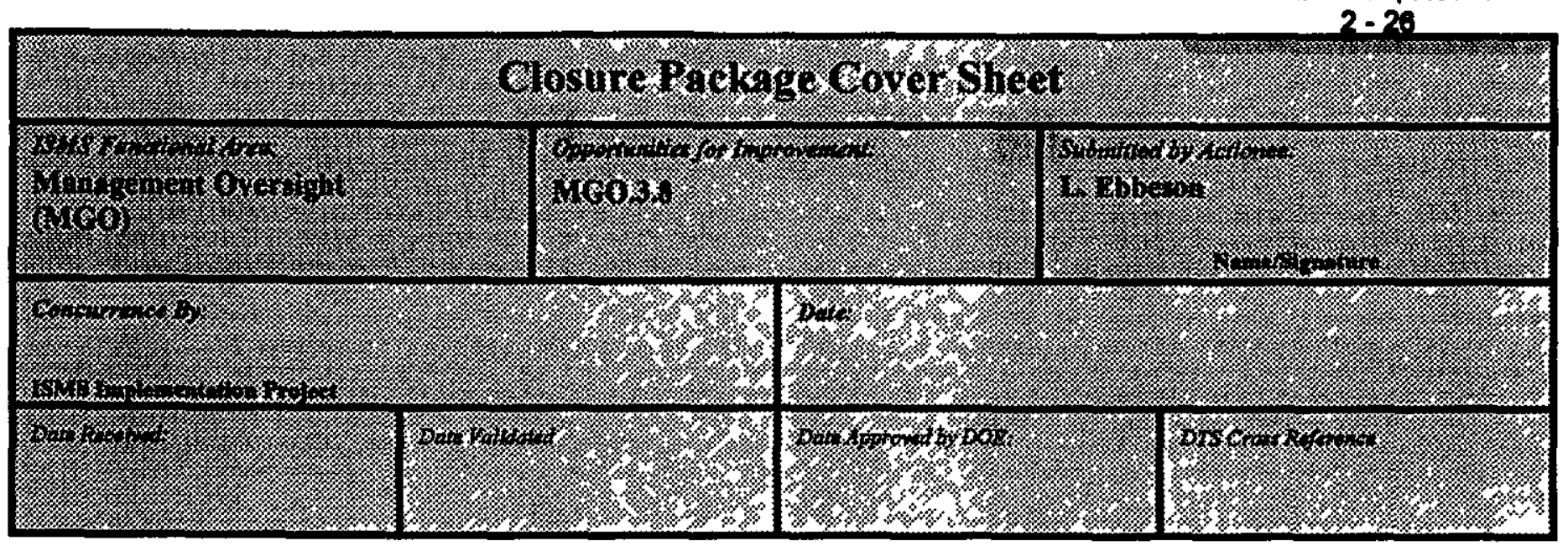




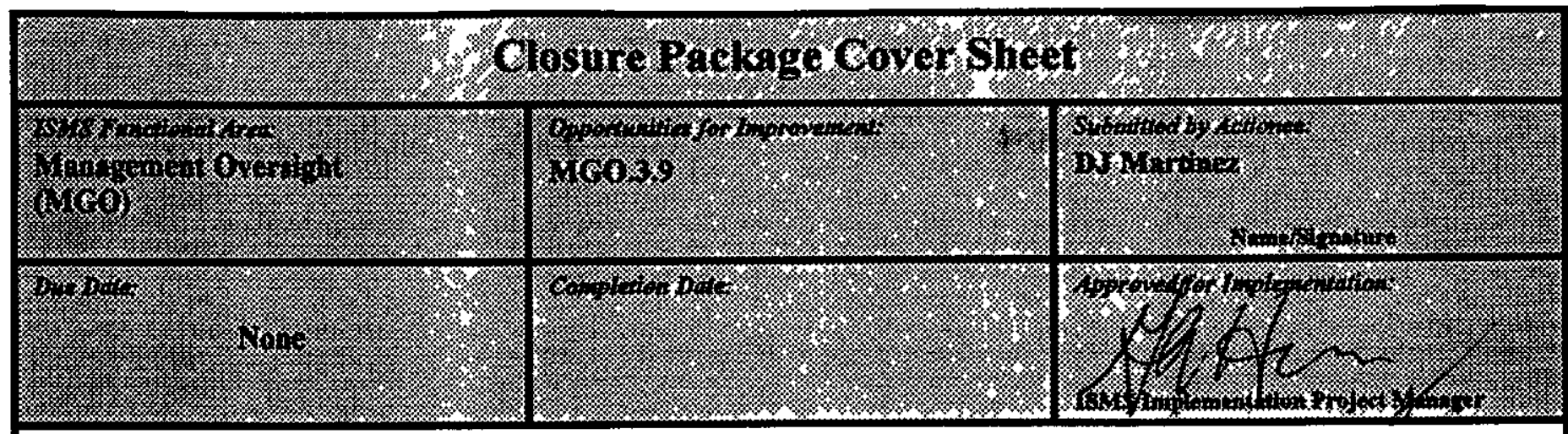

OPPORTUNITIES FOR IMPROVEMENT

Corrective actions resulting from safety concerns within the Employee Concerns process are not tracked in conjunction with the corrective action management process

\section{Commitment}

FDH Management understands the importance of, and is strongly commutted to timely resolution of all employee concerns Actions that must be taken in order to resolve an employee concern are tracked, monitored, and completed prior to the concern being considered "closed" per HNF-PRO-410 This procedure accomplishes those objectives while maintaining a system that provides employees with confidentiality and encourages their open and honest communication in raising any 1ssues that may be of concern HNF-PRO-410 also complies with the Feedback and Improvement Policy - HNF-4467, which requires a process to review available information, analyze trends, and present recommendations to the executive staff as input to the decision making process for performance improvement

The CAM procedure HNF-PRO-052 clearly states that Employee Concerns are not subject to the CAM requirements, unless otherwise determined by management as they are managed through other systems and processes Exceptions are taken to this when the issue is a defined deficiency, which identifies non-compliance or nonconformance of an established requirement in the PHMC contract It is FDH's management decision to contınue separately trackıng items that do not meet the above exception No actions are required

\section{Validation}

The following evidence (letter number reports etc) has been reviewed and are inchuded in the closure package to validate the accuracy and completeness of the commitment

To be completed

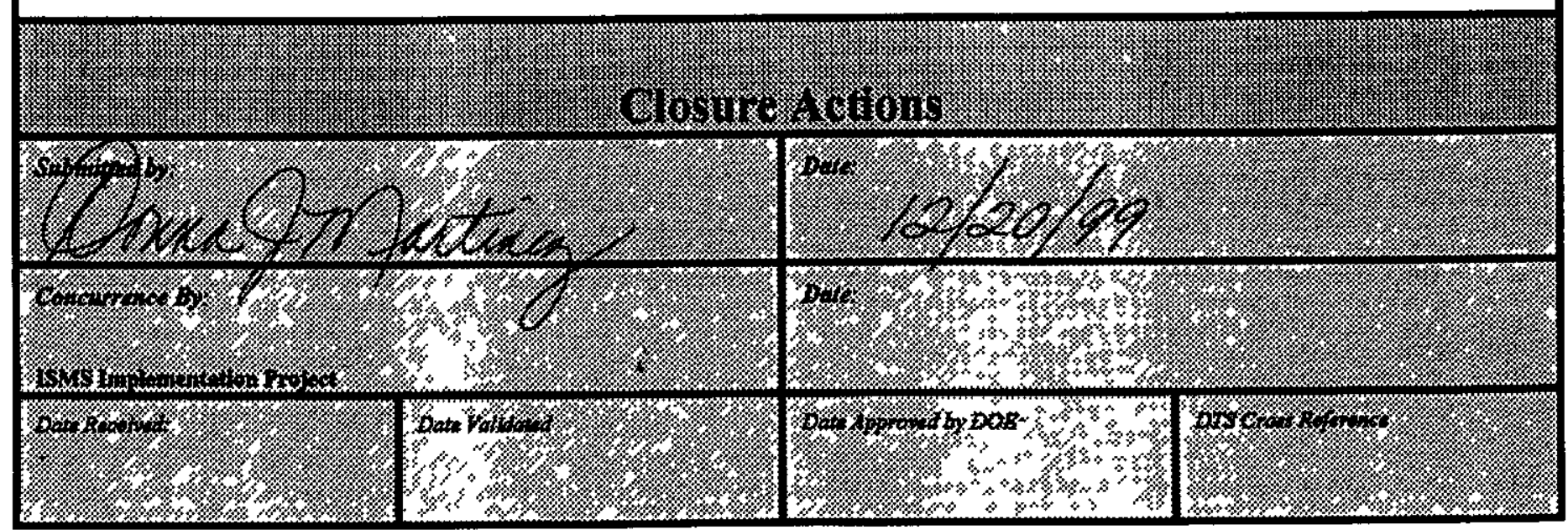




\section{Closure Package Cover Sheet}

\begin{tabular}{|c|c|c|}
\hline $\begin{array}{l}\text { ISMS Functional Area } \\
\text { Management Oversight } \\
\text { (MGO) }\end{array}$ & $\begin{array}{l}\text { Opportunitzes for Improvement } \\
\text { MGO } 41\end{array}$ & Submitted by Actionee \\
\hline $\begin{array}{l}\text { Due Date } \\
\qquad \text { March 2, } 2000\end{array}$ & Completion Date & Approvedfor 1 \\
\hline
\end{tabular}

There is no written guidance for supervisıon of non nuclear work (sımılar to HNF PRO 4616)

\section{Commitment}

HNF PRO 4616 is written to provide minmum requirements and performance expectations for supervision of field work activities at Nuclear facilities and for support system work actıvities The procedure will be revised to reflect that Non Nuclear projects and facilities establısh simslar requirements and expectations for the supervision of field work activities

\section{Subtask 01}

Revise and issue HNF PRO 4616

Due Date $3 / 2 / 00$

\section{Acceptance Criterın}

HNF-PRO 4616 approved for use with specific language included to provide direction to Non Nuclear projects and facilities for establishıng requirements and expectatıons for field work supervision

\section{Valıdation}

7 ho following endence (tetter numb, reports etc) has been reviened and are included in the closure package to i aldate the accul at and completeness of the commiment

To be completed

\section{Closure Actions}

\begin{tabular}{|l|l|l|l|}
\hline Submutted by & \multicolumn{2}{|l|}{ Date } \\
\hline Concurrence By & Date & DTS Cross Referc nce \\
\hline ISUIS Implementation Project & Date Valdated & Date Approved by DOE & \\
\hline Dath Received & & & \\
\hline
\end{tabular}




\begin{tabular}{|c|c|c|c|}
\hline 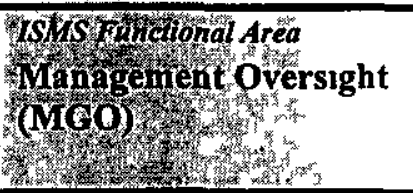 & 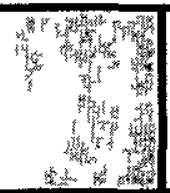 & 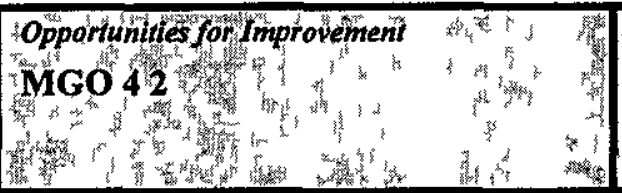 & 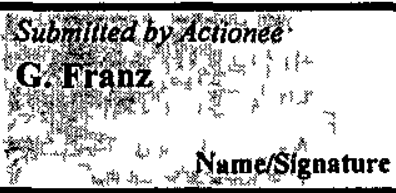 \\
\hline
\end{tabular}

\section{OPPORTUNITIES FOR IMPROVEMENT}

The FDH ISMS Plan (HNF MP 003), appendix B, Section 344 is inconsistent with HNF-PRO 2701 relating to Authorization Envelope and Authorization Agreement

\section{Commitment}

The text in HNF PRO 2701 and the ISMS Plan are both intended to indicate that the Authorization Agreement, which is required for Category 2 nuclear facilities, is somewhat more expansive than, and totally inclusive of, an Authorization Envelope and, as a result the AA would include the AE for those facilities

The text of the ISMS Plan will be revised to make this point more clear

\section{Subtask 01}

Clarıfy the text in the ISM System Description to identıfy the relationship between Authorization Envelope and Authorization Agreement as part of the annual update

Due January 15, 2000

\section{Acceptance Criterıa}

Text in the ISM System Description correctly portrays the relatıonshıp between Authorization Envelope and Authorization Agreement (For Category 1 and 2 nuclear facilities, the Authorization Agreement contains the Authorization Envelope)

\section{Validation}

The following evidence (fetter number reports etc) has been revewed and are included in the closure package to validate the cucuraty und completeness of the commitment

To be completed

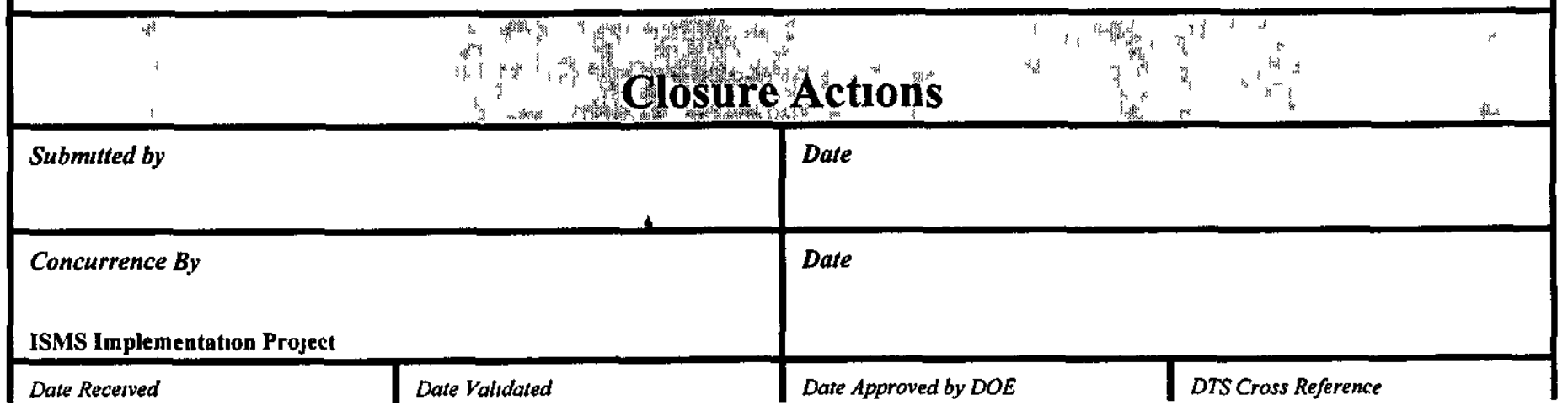




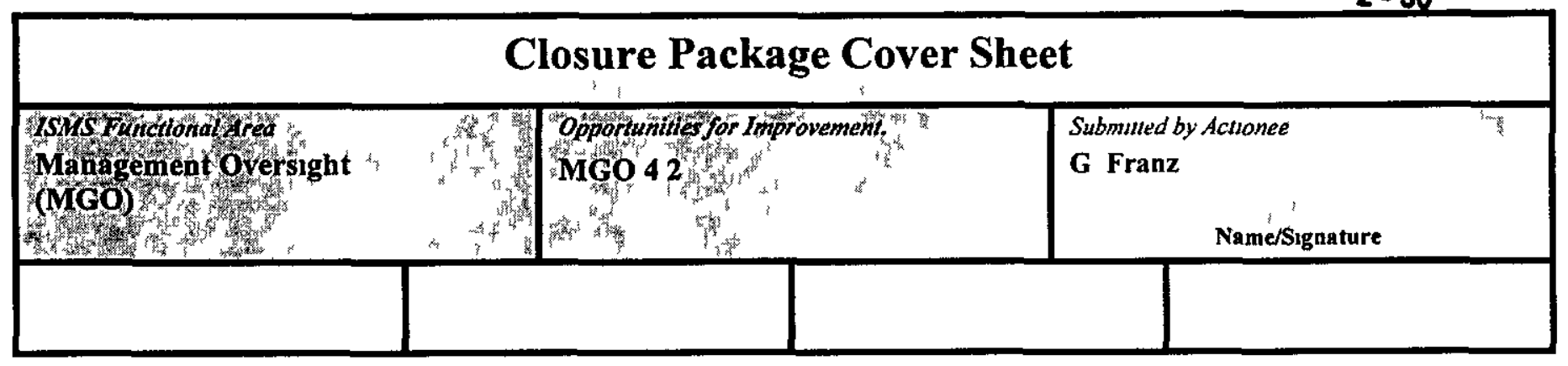




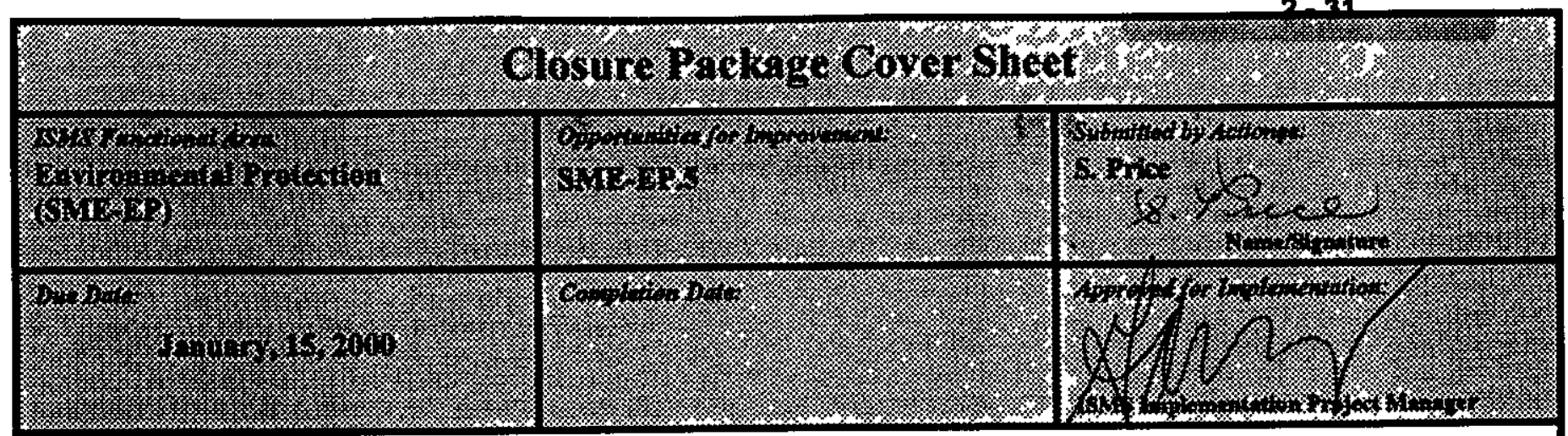

\section{OPPORTUNITIES FOR IMPROVEMENT}

The Technical Authonty listed in all envronmental procedures is no longer in that position, therefore, updates will need to be made reflecting the changes in the reorganization

\section{Commitment}

The Senior Technical Advisor for FDH Environmental and Regulation is currently in the process of identıfying those HNF-PROs which require updates resulting from organizational and personnel changes

\section{Subtask 01}

Senior Technical Advisor will be submitting the recommended changes to the PHMS

Due January, 15, 2000

\section{Acceptance Criteria}

Updated information for Technical Authority listings in EP procedures

\section{Validation}

The following evidence (Netter number reports etc.) has been reviewed and are included in the closure package to validate the accuracy and completeness of the commitment

To be completed

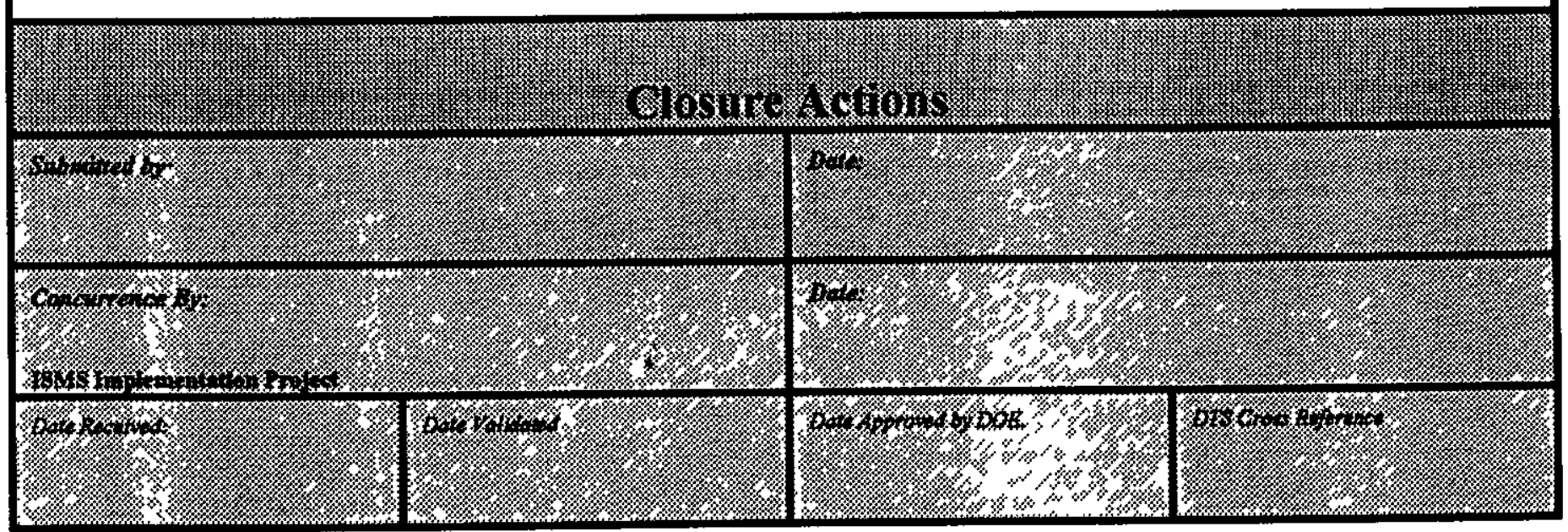




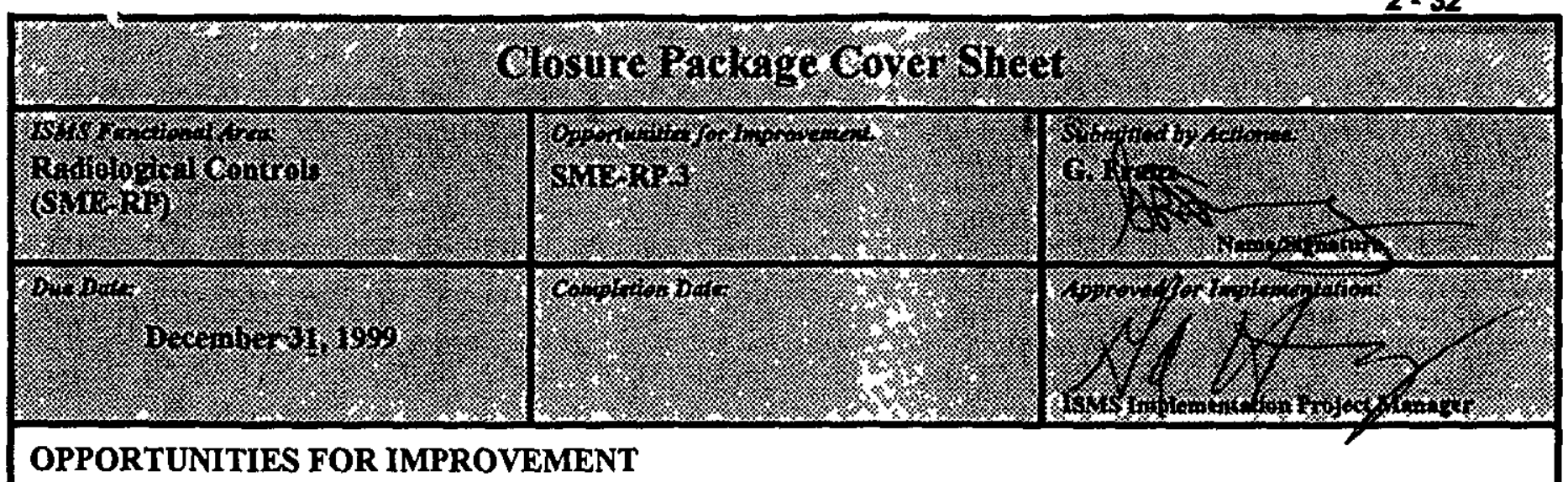

The integration of Facility Authorization Basis administrative controls from ES\&H programs other than the nuclear safety program is not documented at the FDH instıtutional level

\section{Commitment}

The current procedure for Facility Authonzation Basis preparation, approval and implementation is HNF-PRO700 This procedure requires that facilities implement safety basis document commitments This would include elements of the various disciplines required to meet the commitments and to ensure compliance with approved requurements

However, this procedure requirement does not address how the personnel in the field are trained and instructed regarding their specific efforts to accomplish meeting $A B$ requirements Within HNF-PRO-700, wording will be added to strengthen the need for all disciplines involved in $\mathrm{AB}$ implementation to be aware of their responsibilities This will couple up with requirements in other procedures to require as an example, field work supervisor to be trained regarding the $\mathrm{AB}$ for the facility in which they are working All of these serve to emphasize the faclity need to fully implement their $A B$ and ensure ongoing complance

\section{Subtask 01}

Revise HNF-PRO-700 to require that implementation of AB controls involving other ES\&H disciplines includes identification of those roles and responsibilities within the implementing disciplines

\section{Acceptance Criteria}

HNF-PRO-700 revised and approved

\section{Validation}

The following evidence (ietter number reports etc) has been reviewed and are included in the closure package to validate the accuracy and completeness of the commitment

To be completed 
HNF-4554, Rev 3

2 - 33

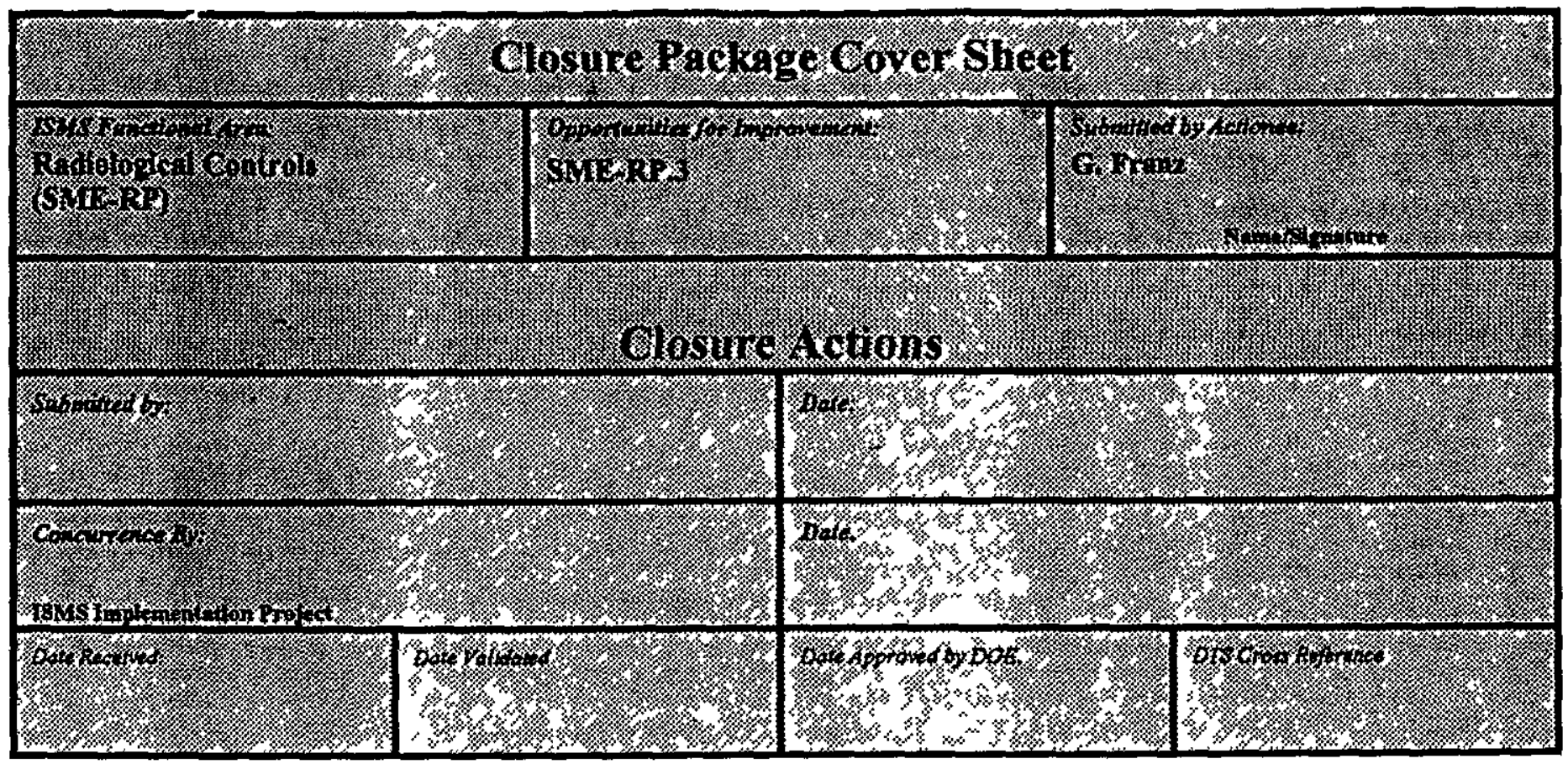




\section{Clasure Rakkigu Cover Sheet}

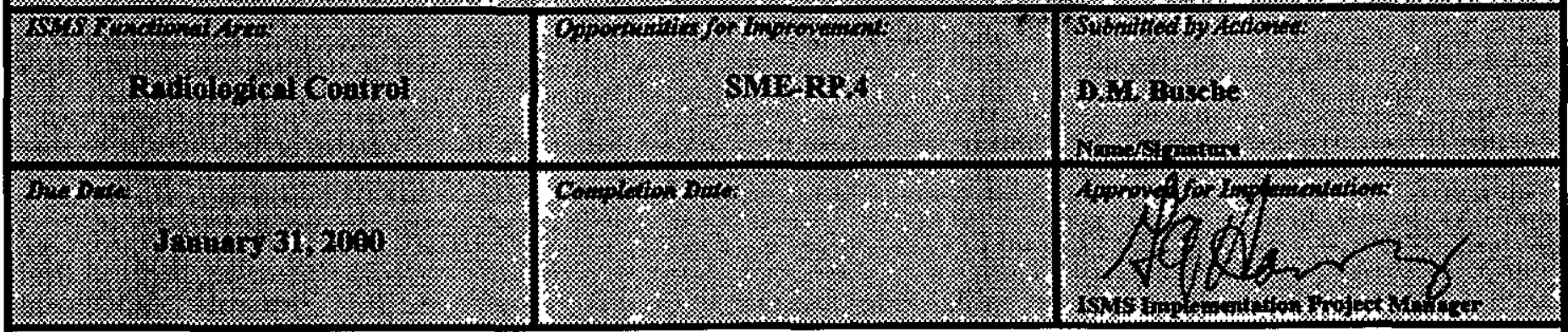

\section{OPPORTUNITY FOR IMPROVEMENT}

Commitment FDH needs to complete development and implementation of the Nuclear Safety Regulatory

Compliance program improvements

\section{Subtask 01}

Establish the PAAA Executive Steering Committee.

Subtask 02

Establish the PAAA Center of Expertise

\section{Subtask 03}

Revise HNF-PRO-2243, Nuclear Safety Requirement Noncompliances to implement 10 CFR 820 Appendix A and associated Office of Enforcement and Investigation procedures and citations

\section{Acceptance Criteria}

\section{Subtask 01}

The PAAA Executive Steenng Committee will be established via official memorandum from the President's Office Obtain a copy of the letter and venfy that the PAAA Executive Steerng Committee has been established

\section{Status Complete}

\section{Subtask 02}

The PAAA Center of Expertise will be established by the Director of Nuclear Safety Regulatory Compliance A Charter will be established to define the membership, roles and responsibility of the COE Obtain a copy of the PAAA Center of Expertise Charter and verify that the COE has been established

\section{Status Complete}

\section{Subtask 03}

HNF-PRO-2243 will be revised to implement 10 CFR 820, Appendix A and associated Office of Enforcement and Investigation procedures and citations Obtain a copy of the revised procedure

Status Due January 31, 2000

\section{Validation}

The following evtdence (etter number reports etc) has been reviewed and are included in the closure package to validate the accuracy and completeness of the commitment

The following documents were developed to implement the Nuclear Safety Regulatory Compliance program improvements Each document has been reviewed and meets the acceptance criteria established for this Opportunity for Improvement

1 Memo, D B Van Leuven, to E S Arom1, et al, Establishment of Executive Steering Committee Regarding Price-Anderson Amendments Act dated October 25, 1999

2 Letter, D M Busche to Distribution, Price-Anderson Amendments Act Center of Expertise Charter dated December 28, 1999

3 Procedure, HNF-PRO-2243, Nuclear Safety Requirement Noncompliances, Rev 1, DRAFT, Effective Date TBD 


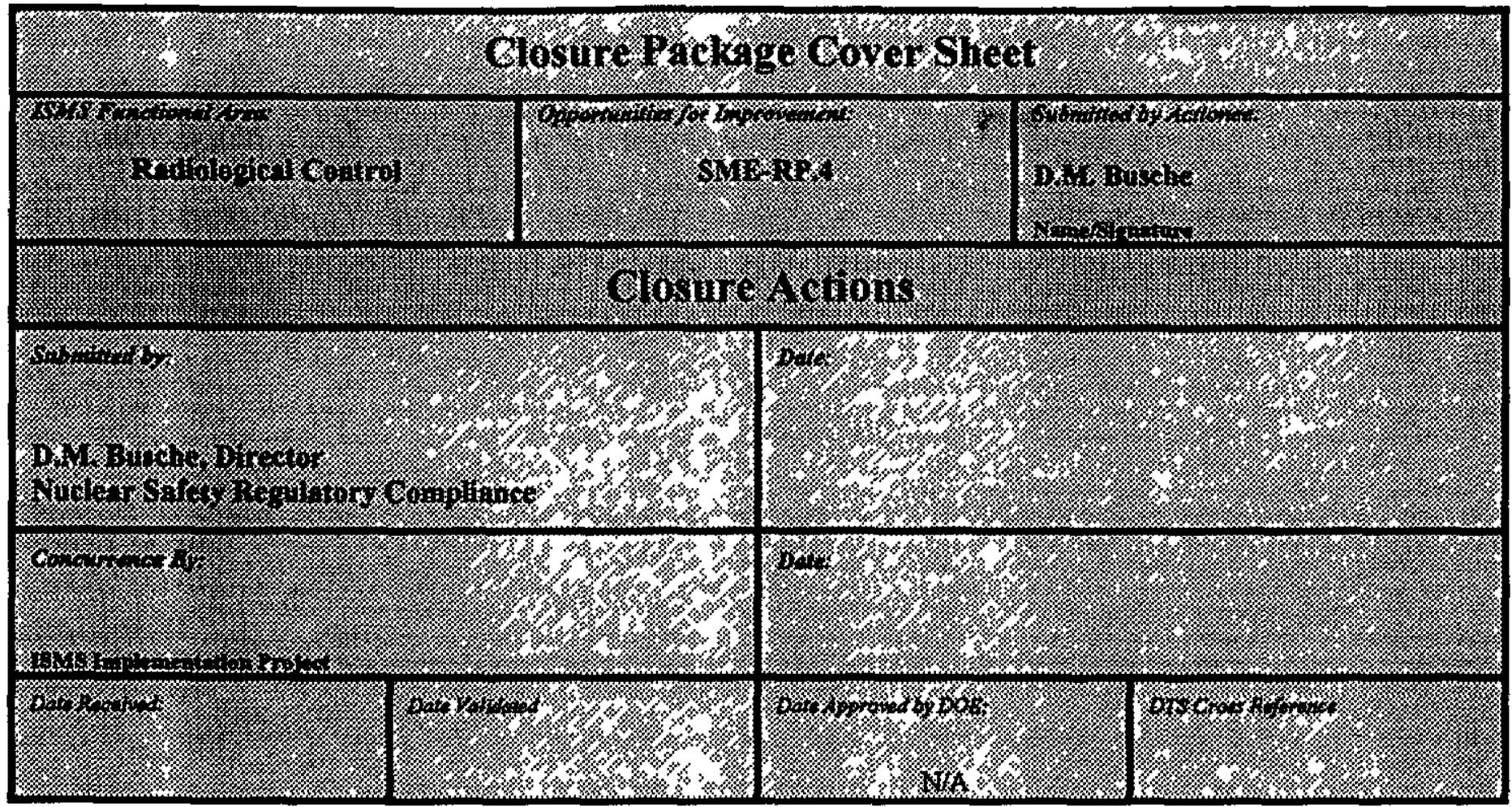




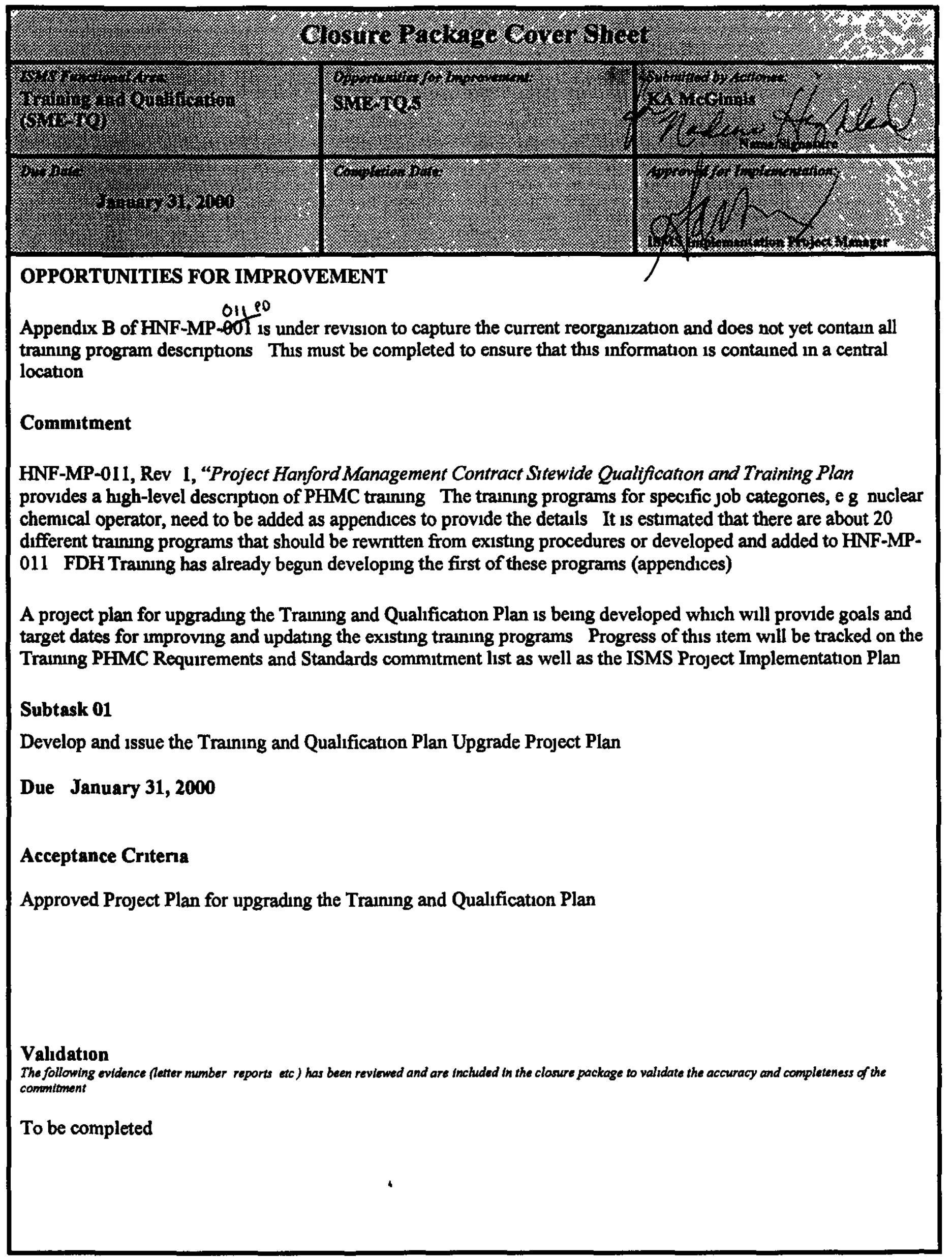


HNF-4554 Rev 3

$2-37$

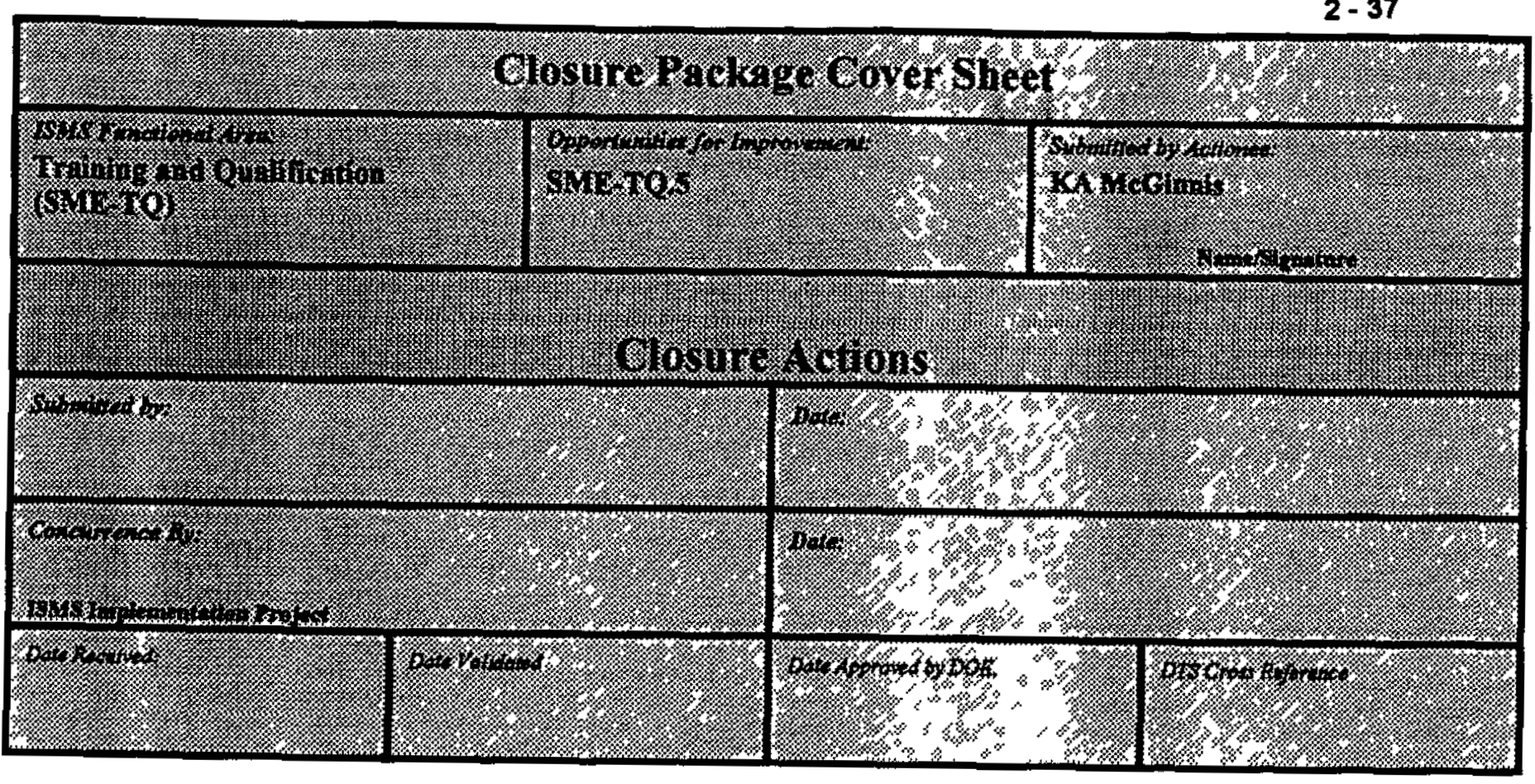




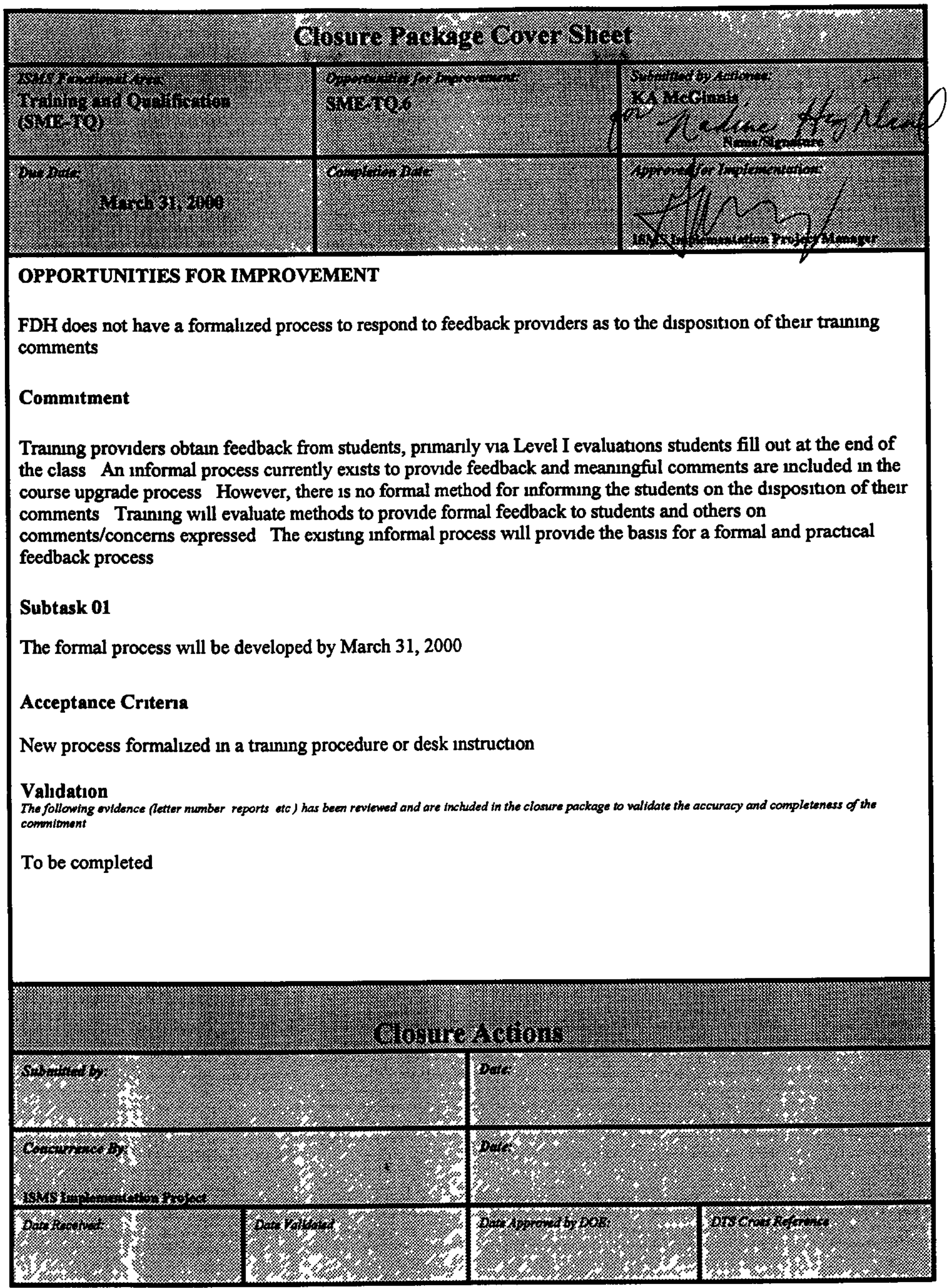




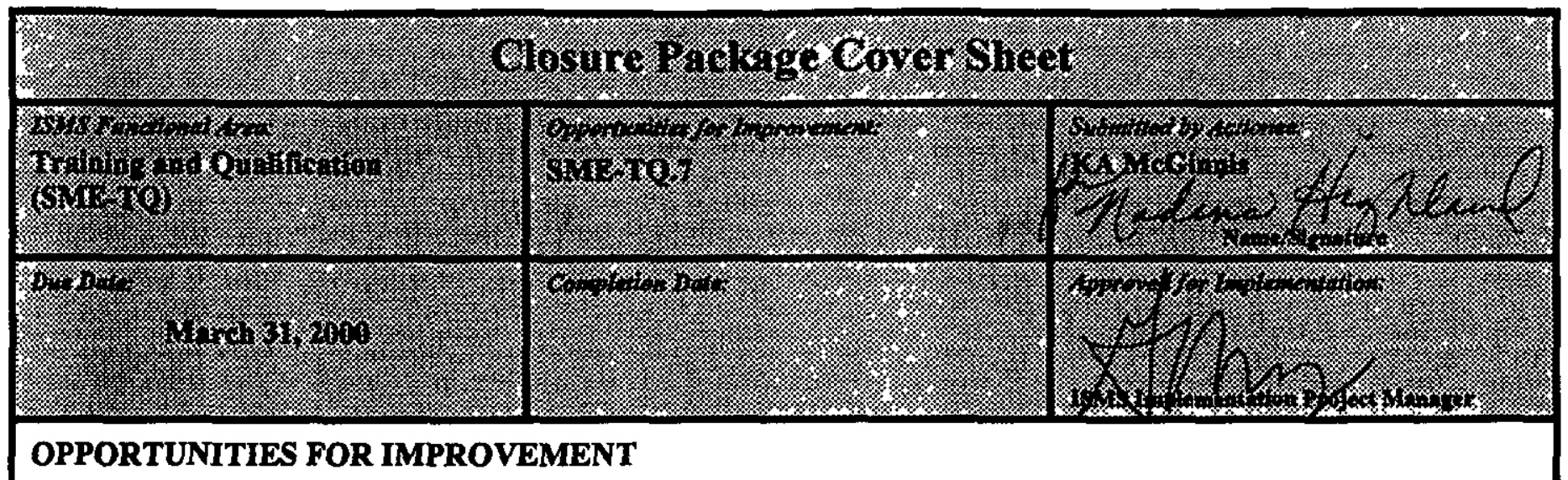

ISMS prnciples and core functions are not incorporated in all ES\&H and Emergency Preparedness training to emphasize and reinforce the concepts with the workforce

\section{Commitment}

The FDH orientation training on ISMS was an excellent introduction into ISMS functions and principles Additional, continuing training would enhance and reinforce these concepts and practices Incorporating ISMS into existing ES\&H and Emergency Preparedness training would couple the concepts with specific applications Training will determine the method(s) to integrate ISMS principles and functions into ES\&H and Emergency Preparedness training Training is considening a two-phased approach An interim "add-on" to these courses and long-term incorporation of ISMS into the penodic updates

\section{Subtask 01}

Conduct evaluation of current programs Due date $01 / 31 / 00$

\section{Subtask 02}

Develop interım "add-on" module Due date 03/31/00

\section{Subtask 03}

Incorporation of ISMS functions and principles during penodic course updates Updates will be initiated after approval of "add-on" defined in Subtask 02 and will be ongoing

\section{Acceptance Criteria}

Approved documentation describing the "add-on" feature to established training courses and the process for incorporation of ISMS concepts in the development of new courses is in place

\section{Validation}

The following evidence (letter number reports etc) has been reviewed and are inchuded in the clasure package to validate the accuracy and completeness of the commitment

To be completed 
HNF-4554 Rev 3

2 - 40

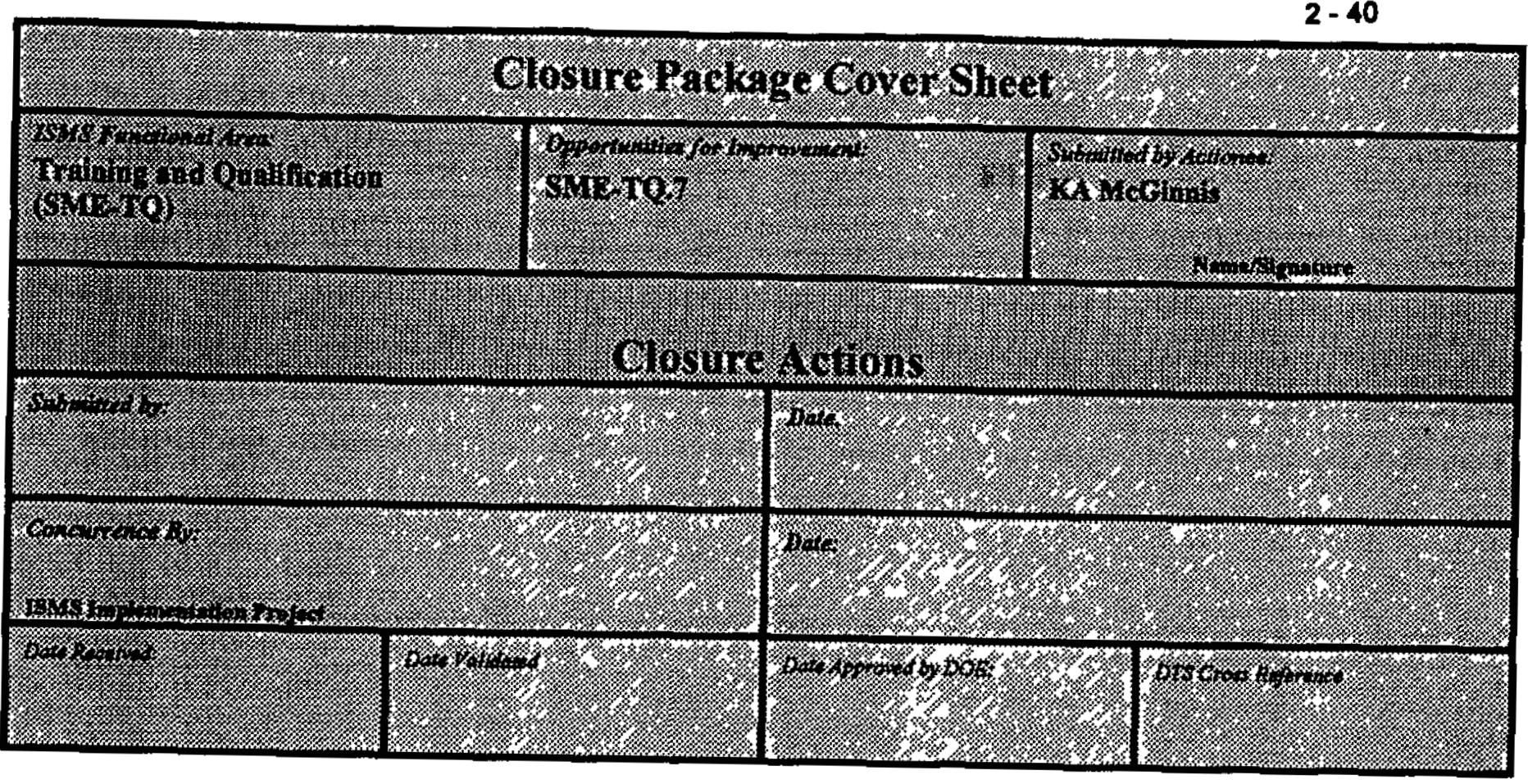




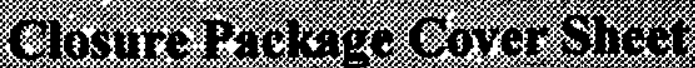

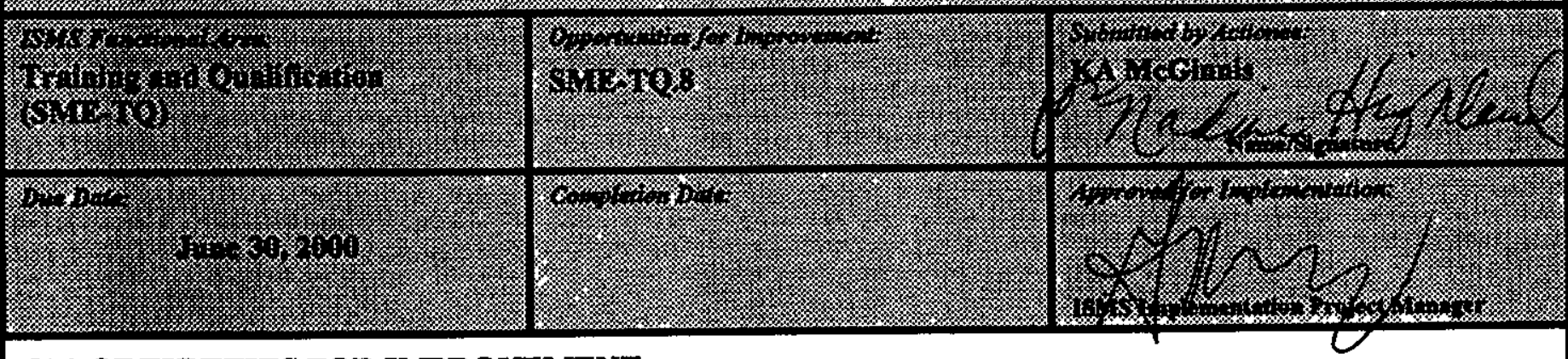

\section{OPPORTUNITIES FOR IMPROVEMENT}

Further action is necessary to complete the development of a formal training program for managers to ensure they are able to effectively perform all roles and responsibilities

\section{Commitment}

Present training required for managers covers regulatory and contract driven requirements, but does not cover management systems, personnel skills, etc FDH recognizes this as an area for increasing the effectiveness of its managers Training and Human Resources are initiating a joint effort to develop and conduct such a program

\section{Subtask 01}

Begin Analysis phase of the program by November 30, 1999

\section{Subtask 02}

Determine general course content by January 31,2000

\section{Subtask 03}

Develop course outline by Apnl 28, 2000

\section{Subtask 04}

Begin phased implementation of the training program by June 30,2000

\section{Acceptance Criteria}

Documentation of approved lesson plan(s)

\section{Validation}

The following evidence (letter number reports ete) has been reviewed and are included in the closure package to validate the accuracy and completeness of the comontoment

To be completed 
HNF-4554 Rev 3

242

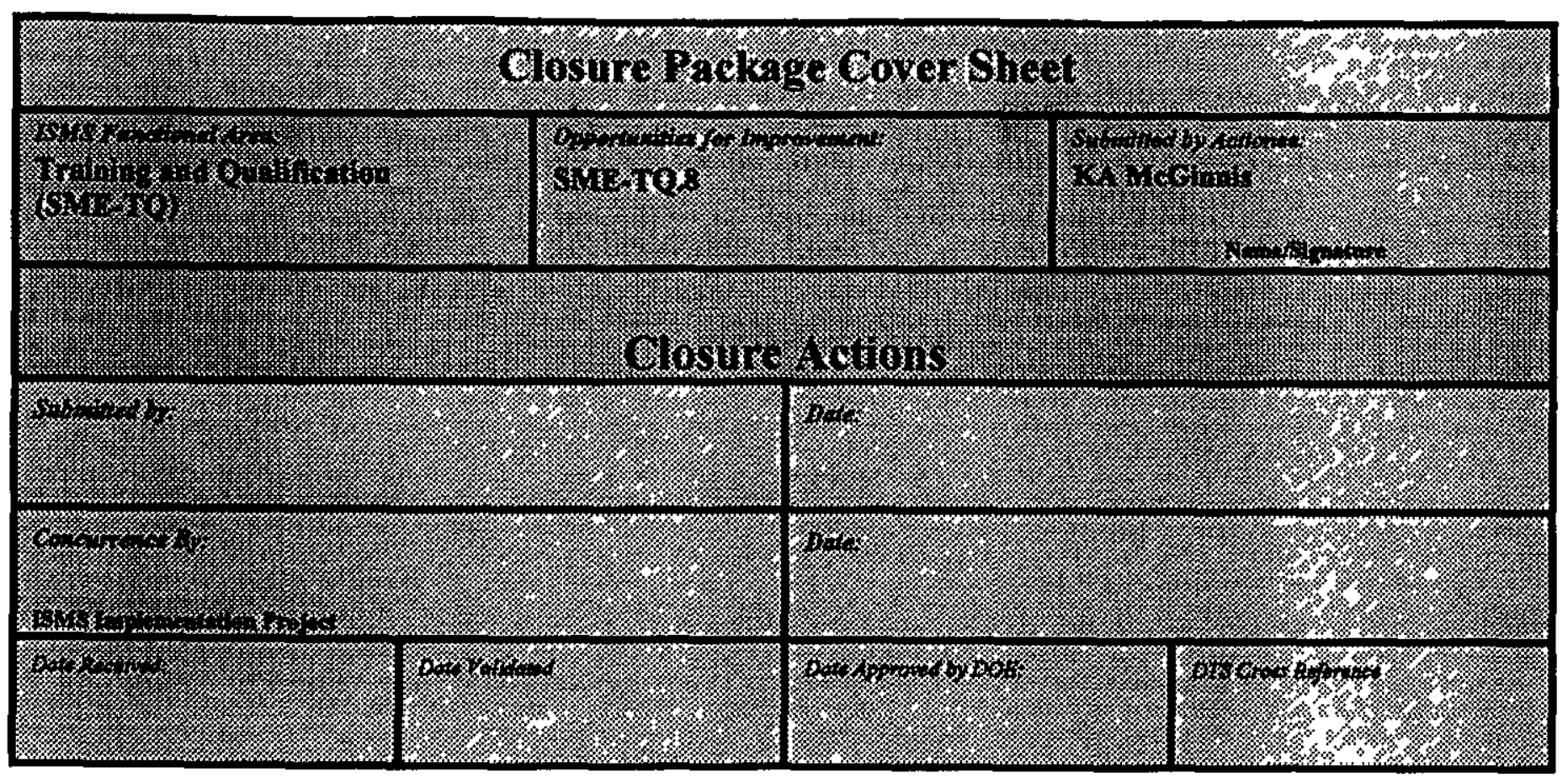


HNF-4554, Rev 3

Attachment 3

Fluor Hanford, Inc

Integrated Environment, Safety and Health

Management System

\section{VERIFICATION SCHEDULE}

Consistıng of 2 pages 


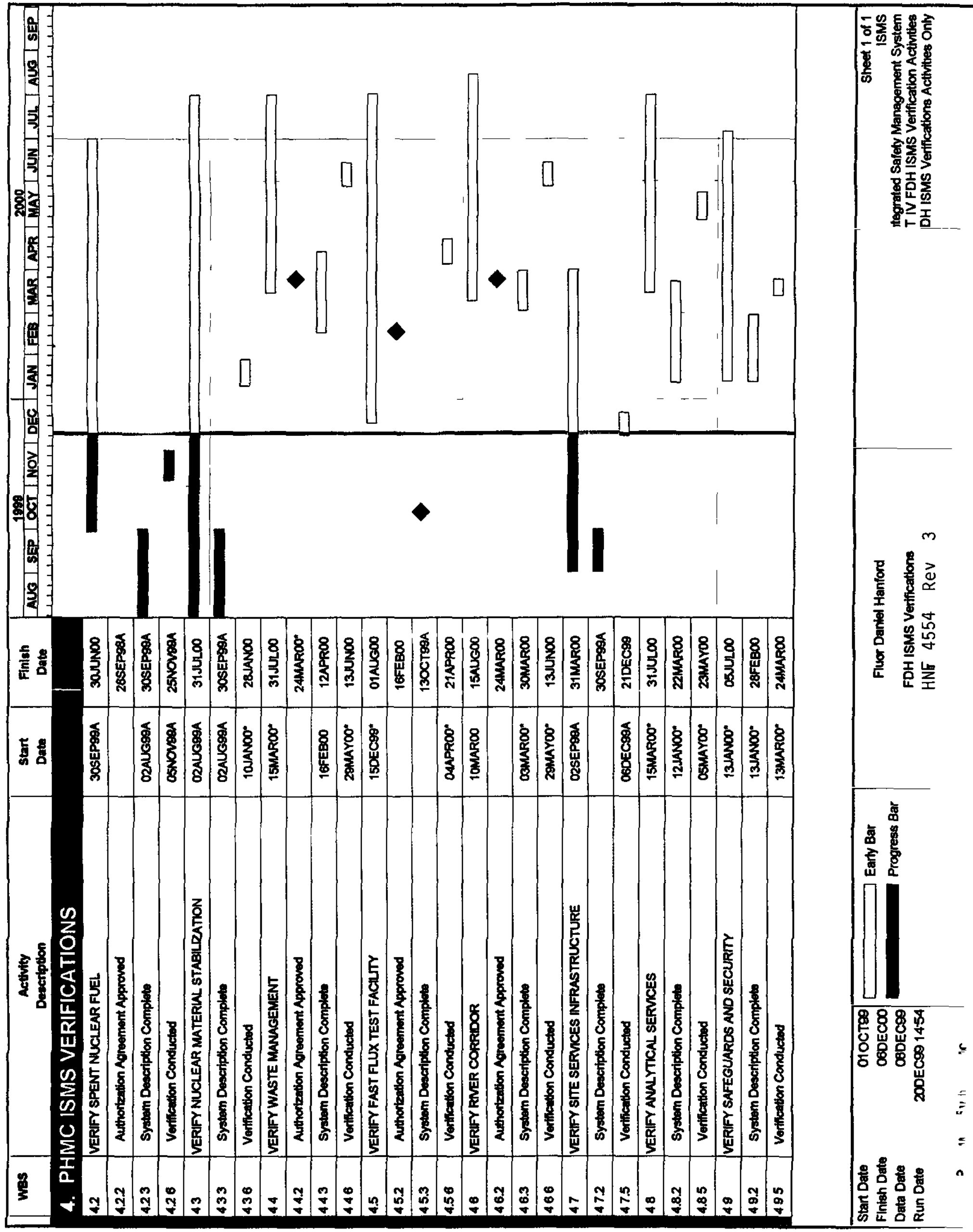

